\title{
The Water-Energy-Food Nexus Index: A Tool for Integrated Resource Management and Sustainable Development
}

\author{
Gareth B. Simpson ${ }^{1,3^{*}}$, Graham P.W. Jewitt ${ }^{2,3}$, William Becker ${ }^{4}$, Jessica Badenhorst ${ }^{1}$, \\ Ana R. Neves ${ }^{5}$, Pere Rovira ${ }^{6}$ and Victor Pascual ${ }^{6}$ \\ ${ }^{1}$ Jones \& Wagener (Pty) Ltd, Centurion, South Africa \\ ${ }^{2}$ IHE Delft Institute for Water Education, Delft, Netherlands \\ ${ }^{3}$ Centre for Water Resources Research, College of Agriculture, Engineering and Science, \\ University of KwaZulu-Natal, Pietermaritzburg, South Africa \\ ${ }^{4}$ formerly Joint Research Centre, Competence Centre on Composite Indicators and \\ Scoreboards, Ispra, Italy \\ ${ }^{5}$ Joint Research Centre, Competence Centre on Composite Indicators and Scoreboards, Ispra, \\ Italy \\ ${ }^{6}$ OneTandem SL, Barcelona, Catalonia, Spain
}

Correspondence:

* Corresponding author: simpson@jaws.co.za

Keywords: WEF Nexus, Sustainable Development Goals, Composite Indicator, South Africa, SDG

\begin{abstract}
The Water-Energy-Food (WEF) nexus has, in the past decade, gained prominence as an approach for assessing integrated resource management. One challenge related to the WEF nexus approach is how to represent and monitor it since a system that includes water-, energyand food-related parameters is complex. Not only are these resources quantified utilising different units, but they vary both spatially and temporally.

This paper presents a national-level composite indicator that has been established for 170 countries, utilising the methodology developed by the Joint Research Centre: Competence Centre on Composite Indicators and Scoreboards. Following an assessment of 87 globally applicable water-, energy- and food-related indicators, 21 were selected to constitute the WEF Nexus Index. This index is made up of three equally weighted pillars representing the three constituent resource sectors, and six sub-pillars. A core element in the development of this index is equitable access to resources, which is characterised by each resource sector's 'access' sub-pillar.
\end{abstract}

The WEF Nexus Index provides a quantitative perspective and offers a lens for evaluating trade-offs to be considered in the pursuit of sustainable development. To this end, it is intended for assessing national progress relating to integrated resource management as well as supporting decision making and policy development. The relevance and usefulness of the outcomes are demonstrated through an assessment of South Africa.

The development of the WEF Nexus Index has demonstrated that no country is undertaking integrated resource management flawlessly. Every nation has the potential for improvement; which is evidenced by, for example, the top-ranking country for the index needing to reduce $\mathrm{CO}_{2}$ emissions. Neither the composite indicator nor the WEF nexus approach is, however, the panacea that will solve all the significant development or environmental challenges facing the global society. It can, however, contribute to integrated resource management and is 
complementary to the Sustainable Development Goals. It should ideally be utilised as an entry point into the underlying pillars, sub-pillars and indicators, in parallel with other qualitative and quantitative studies.

\section{Introduction}

An increase in food prices is considered to be a critical indicator of escalating natural resource scarcity, and the present century has witnessed numerous spikes in this regard (Mohtar and Daher 2012, Ringler et al. 2013). Predictions are that the global demand for resources such as water, energy and food are going to escalate dramatically in the coming decades (Beddington 2009, World Economic Forum 2011, National Intelligence Council 2012, WWF and SABMiller 2014). This increasing demand is being driven by a worldwide population that continues to grow exponentially; not only in numbers but also in consumption patterns, primarily due to a burgeoning middle class and urbanisation (FAO 2018). A further stressor is that the international supply chain system must deliver products and resources on a planet where predominant risks include extreme weather events, natural disasters, the failure of climate change mitigation and adaptation, and water crises (World Economic Forum 2018). The solemn nature of this situation is underscored by the warning of Steffen et al. (2018) who state that "the Earth System may be approaching a planetary threshold that could lock in a continuing rapid pathway toward much hotter conditions." Salam et al. (2017) argue that "The gap between future availability and demand can be closed not through the discovery of more water supplies but through effective demand-side management, which will need effective policy interventions."

Following the 2008 financial crisis, concerns were raised that if finite resources such as water are not effectually managed, then the environment, livelihoods and economic development will be adversely impacted (Beddington 2009, Rockstrom et al. 2009, Beddington 2010). The water, energy and food security trilemma (Wong 2010) was also highlighted, and since 2011 significant attention has been given to the Water-Energy-Food (WEF) nexus in the academic, policy, regulatory and development fraternities. The Bonn2011 Conference (Hoff 2011) and the World Economic Forum's publication Water Security: The Water-Food-Energy-Climate Nexus (World Economic Forum 2011) were enormously influential in this regard. In the past decade, the WEF nexus has emerged as a multi-centric lens for assessing integrated resource management and sustainable development (Weitz et al. 2017, Simpson and Jewitt 2019a).

The word nexus means to 'connect' (De Laurentiis et al. 2016). The view that water resources, energy generation and food production are interdependent is not novel (Allouche et al. 2015, Muller 2015, Wichelns 2017). Sušnik (2018) argues that the earliest global study on a nexus was the publication The Limits of Growth (Meadows et al. 1972). A critical motivation for considering the WEF nexus approach is that it is multi-centric, with each sector having equal importance (Abdullaev and Rakhmatullaev 2016, Gallagher et al. 2016, Benson et al. 2017, Liu et al. 2017). One goal of nexus studies is that the trade-offs resulting from policy development in institutional 'silos' will be reduced (Belinskij 2015).

The WEF nexus approach has, however, not been without criticism, with Cairns and Krzywoszynska (2016) considering it to be a "buzzword". Several recent publications have argued that the approach has not lived up to its potential (Albrecht et al. 2018, FAO 2018, Galaitsi et al. 2018). Their critique may be summarised in the statement by McGrane et al. (2018) that the nexus fraternity must migrate from 'nexus thinking' to 'nexus doing.' The nexus should, therefore, be quantified and operationalised as opposed to merely being a philosophical approach or framework. The imperative to integrate quantitative and qualitative nexus 
assessments has been highlighted in recent literature (FAO 2018, Galaitsi et al. 2018, Allouche et al. 2019, Hoff et al. 2019, Simpson and Jewitt 2019b).

An additional motive for pursuing the WEF nexus is that it is a mechanism for achieving the relevant sector-related Sustainable Development Goals (SDGs), i.e. SDGs 2 (zero hunger), 6 (clean water and safe sanitation), 7 (affordable and clean energy) and 13 (climate action). Brouwer et al. (2018) contend that "the Nexus concept is a sound tool to support the sustainable management of resources across sectors, suitable for addressing the challenge of the next few years, namely achieving the Sustainable Development Goals." Ringler et al. (2013) suggested that the SDGs would present a crucial test for implementing the nexus approach at an international level. Yet to date "no country is on track to achieve all the goals by 2030" (Sachs et al. 2018).

While there has been a considerable effort to develop tools to monitor progress towards the SDGs (Sachs et al. 2019), there is less progress in assessing trade-offs between different SDGs or resource sectors such as those represented by the WEF nexus. Human society is at the centre of the global supply chain system while also being the regulator of this multifaceted framework. The linkages, inequalities, synergies, trade-offs, and limits to growth associated with the nexus must be monitored, understood, communicated, managed and regulated. A means of indicating whether a country is achieving a balance in securing these three resource sectors and monitoring progress (or regress) over time would be an invaluable policy tool.

\section{Measuring of the WEF Nexus}

Despite there being a stark disparity in the distribution of wealth as nations developed, researchers started to realise almost a half-century ago that there are limits to anthropogenic progress (Meadows et al. 1972). The global society has recognised that resources such as agricultural land, minerals and water are finite. Various indicators were developed to monitor aspects related to economics, development, the environment and sustainability. The required data are collected by national statistical offices, development organisations and research institutions. The Gross Domestic Product (GDP) was one of the first indicators that was extensively utilised.

Evaluating and communicating the level of trade-off between the water, energy and food sectors is complicated because the individual sectors within this system are quantified with different units of measurement (de Loë and Patterson 2017, Wichelns 2017). They also vary spatially and temporally. One means of assessing such a multifaceted system is through the development of a composite indicator (or index), which results "when individual indicators are compiled into a single index on the basis of an underlying model" (OECD 2008). The methodology set out by the Joint Research Centre's Competence Centre on Composite Indicators and Scoreboards (JRC:COIN) has been adhered to in this study (Saisana et al. 2018). The JRC:COIN have been involved in over 60 statistical audits of composite indicators, amongst others, the Environmental Performance Index (Yale University, Columbia University), the Global Innovation Index (INSEAD \& World Intellectual Property Organisation), the Commitment to Reducing Inequality Index (Oxfam), the Financial Secrecy Index (Tax Justice Network), the Multidimensional Poverty Assignment Tool (UN International Fund for Agricultural Development), the Global Competitiveness Index (World Economic Forum), and the Corruption Perceptions Index (Transparency International) (Saisana et al. 2018).

The JRC:COIN's methodology requires that a conceptual framework be developed for the context under assessment. This framework is subsequently utilised to guide the selection of a 
set of relevant and available indicators. These indicators are normalised, weighted and aggregated, thereby yielding a unitless index that represents the context being appraised. This index is complementary to the underlying data and represents it in a coherent manner. The index is also an access point to the complex data set upon which it is based, thereby enabling the identification of patterns and trends. Indices must be developed sensibly and transparently, and used responsibly, since they can be misused (Saisana et al. 2018). Figure 1 shows that indicators and indices are developed from data to yield information that can ultimately be used for decision- and policy-making. As knowledge is developed, it can, in turn, influence the data collection and indicators for refining the process. Other quantitative and qualitative studies can augment the information generated, and various feedback loops can improve and optimised the data gathering process.

Many composite indicators have been developed in the last three decades (Sullivan 2002, Abeyasekera 2003, Jha and Murthy 2003, Esty et al. 2005, Waas et al. 2014, Sachs et al. 2016, de Vito et al. 2017, Transparency International 2018, Wendling et al. 2018). Some groupings, for example, advocacy groups, view composite indicators as a valuable tool to further their causes. Others, such as cautious professional statisticians, are wary of composite indicators due to the potentially subjective nature of the selection of the constituent indicators, the method of aggregation, the weighting of the indicators, and the interpretation thereof (Saisana et al. 2018).

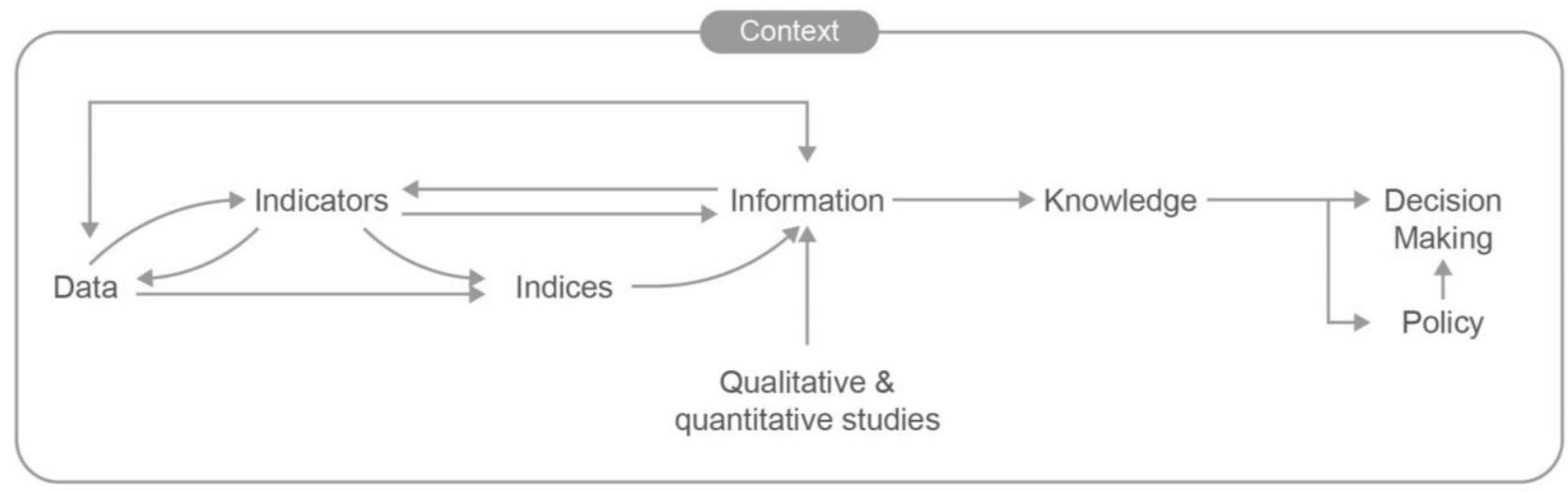

Figure 1: From data to decision making; modified from Segnestam (2002) and Waas et al. (2014)

\section{Methodology}

This section describes the methodology associated with the development of the WEF Nexus Index (Simpson et al. 2020). Associated with this academic paper are four addendums:

- Addendum A: The indicator selection table, which presents the 87 indicators reviewed in the development of the WEF Nexus Index, as well as their definitions, source, data adequacy, reference year, and a motivation of why each indicator was, or was not, included in the composite index.

- Addendum B: The untreated indicator data table includes the published data (e.g. by the World Bank, International Energy Agency (IEA) and the Food and Agriculture Organization of the United Nations (FAO)) for the 21 indicators that constitute the WEF Nexus Index, for the 170 nations that have adequate data.

- Addendum C: A table presenting the conceptual framework associated with the WEF Nexus Index's composition. This table includes the index, pillars, sub-pillars and indicators with each of their weights, forms of aggregation, and directions. 
- Addendum D: A dashboard developed from the treated data. The published data for the 21 indicators have been treated by normalising each of the data sets (using the min-max method (OECD 2008, Saisana et al. 2018)) so that they conform to a range from 0-100. The normalising of the data is also necessary to ensure that each indicator's data set is unitless such that it can be combined in the composite indicator. The data treatment includes the minimising of the distorting effect of outliers on the data using statistical methods, which are described in this article. The dashboard has different colours for the treated data for each indicator in the following ranges: $0-25 \% ; 25-50 \% ; 50-75 \%$; and $75-100 \%$.

\subsection{Hypothesis}

A hypothesis related to this study is that there is sufficient, relevant water-, energy- and foodrelated indicator data to develop a global, country-level WEF nexus-based composite indicator that can be utilised for assessing the status of integrated resources management. This index would not be a one-size-fits-all solution to solving integrated resource challenges. Rather, the WEF Nexus Index provides an entry point for nexus assessments that seeks to meets the guidance of Hoff et al. (2019), i.e. aiming to create "a level playing field for all sectors while at the same time having sustainability (as defined in the SDGs) as an overarching aim." How this goal is operationalised and met would, however, depend on the unique case and the actors involved.

The purpose of the development of the WEF Nexus Index is to develop a country-level quantitative, integrated measurement of resource security as it relates to access to, and availability of, water, energy and food. It provides a measure of the degree of achievement of SDGs 2, 6, 7 and 13. It is a tool, lens and means for initiating integrated resource management, not as an end in itself. It is supported by a strong emphasis on data visualisation and representation.

\subsection{Development of the framework}

According to the JRC:COIN, the first step in forming a composite indicator is the development of a framework for the system under assessment (Saisana et al. 2018). To this end, the anthropocentric WEF nexus framework, presented in Figure 2, was utilised as the basis for the WEF Nexus Index's construction. At the core of this framework is human society, i.e. Anthropos (Greek for human), with its insatiable demand for resources. Globally, access to resources such as water, energy and food is not equitable, hence the inclusion of three water-, energy- and food-related SDGs in this framework. Each SDG has targets that "are universally applicable and aspirational" (UN Water 2018). SDG 6, for example, has eight global targets. The framework also reflects the priorities of the global South in achieving both access to and provision of resources (Simpson et al. 2020).

Further, these resources are procured from the environment in manners that are either renewable or non-renewable. The environment, land and climate are represented by the outer layers of this framework since, in many cases, planetary boundaries are being tested or even exceeded (Steffen et al. 2018). The framework also demonstrates that while humanity is at the centre of the global supply chain system, they are also custodians of the governance and policies related to these three interdependent resources. 


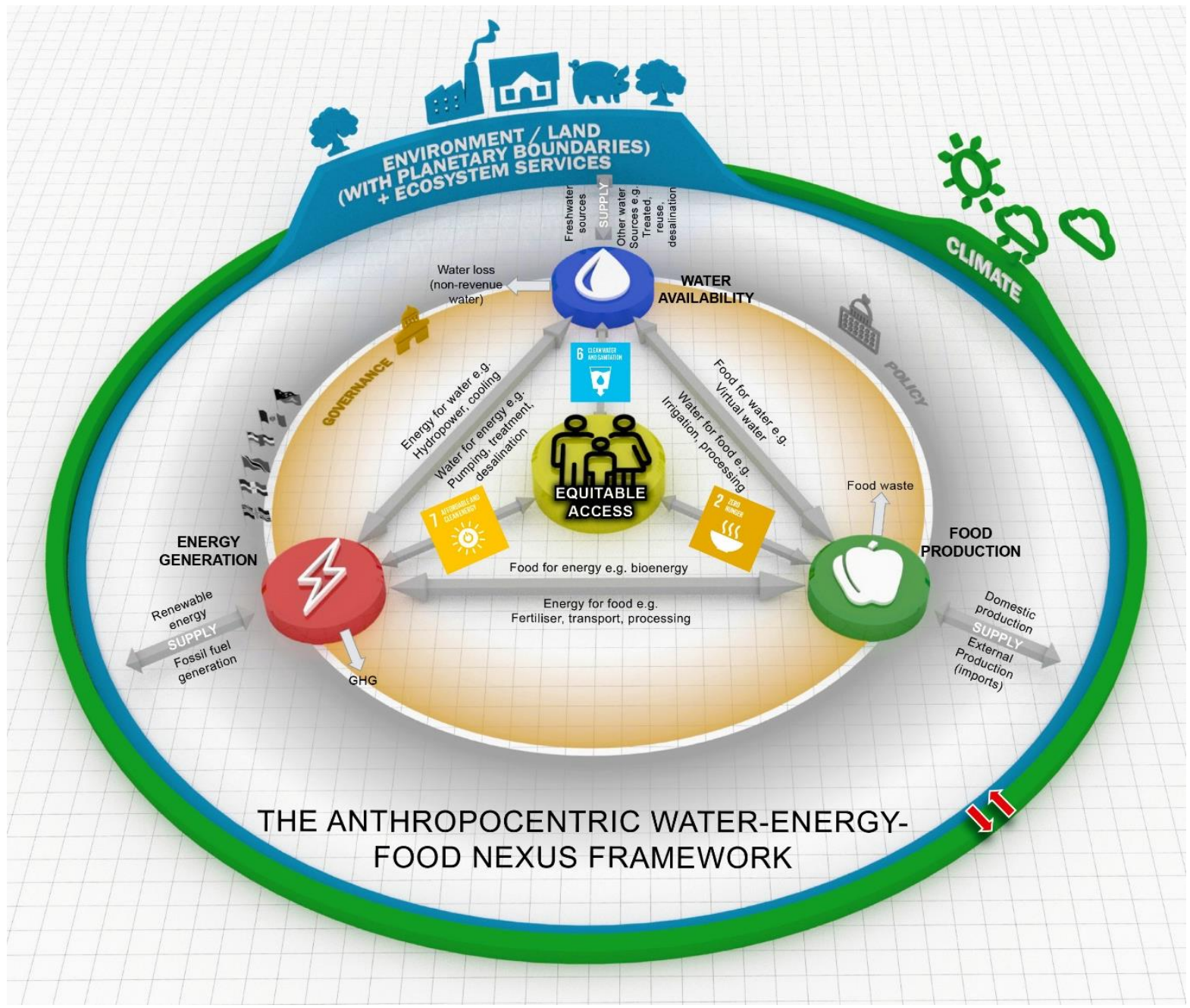

Figure 2: The Anthropocentric Water-Energy-Food Nexus Framework (Simpson et al. 2020)

Based on this framework, the WEF Nexus Index has three equal pillars representing water, energy and food, as presented in Figure 3. Each of these resource sectors, in turn, have "Access" and "Availability" sub-pillars. The "Access" component of the WEF nexus relates to the urgent need for worldwide distributional justice, i.e. equitable access to resources. This is the perspective from which the WEF Nexus Index was developed (Simpson et al. 2020). While equitable access to resources is essential, the physical availability thereof is of equal importance. The energy-access pillar, therefore, includes an access indicator, two indicators that represent renewable energy consumption and output and an indicator related to $\mathrm{CO}_{2}$ emissions per capita (refer to Figure 3). This is because this pillar relates to SDGs 7 and 13, i.e. access to modern energy that addresses climate action.

\subsection{Selection of indicators}

The next stage in the development of a composite indicator, according to JRC:COIN, is the selection of the indicators that will constitute the index. The framework and index, pillar and sub-pillar structure developed for the system under assessment were utilised to guide the selection of the indicators presented in Figure 3. Internationally, data are collected by various organisations such as national statistical offices, government departments, non-governmental organisations and international organisations such as the World Bank, FAO, IEA and World 
Health Organisation (WHO). A global search of these databases resulted in a list of 87 water, energy- and food-related indicators that were subsequently reviewed for both relevance and data availability at a national scale via a rigorous and iterative process. For an indicator to be included in an index, at the indicator level at least $65 \%$ of countries should have valid data. Similarly, and at the country level, at least $65 \%$ of indicators should have valid data (Saisana et al. 2018).

Selection criteria included relevance, added value, data availability, and reliability, together with a correlation analysis to identify possible aggregation issues or double-counting (Simpson et al. 2020). If the correlation of the indicators is too high, taken to be equal to or greater than 0.92 in this study, then this constitutes double-counting, i.e. effectively including the same variable twice (OECD 2008). In this case one of the highly correlated indicators was omitted from the WEF Nexus Index.

Details of each indicator evaluated, and a rationale for its inclusion or exclusion in the WEF Nexus Index is provided in Addendum A. One of the challenges experienced in the selection of indicators is that there are very few indicators that measure the linkages between the constituent sectors, i.e. 'nexus' indicators that measure water for energy, water for food, energy for water, etc. Where these 'nexus' or 'integrated' indicators do exist, they are invariably reported by too few countries to form part of the index. These indicators could, however, form part of an in-depth study for countries that report these parameters.

Both the anthropocentric framework (refer to Figure 2) and the selection of indicators to form the WEF Nexus Index were presented at various forums during this project to facilitate stakeholder/expert engagement. These interactions proved to be beneficial in obtaining vital input on both the interpretation of the framework and the final selection of indicators. The forums that the conceptual framework and indicators were presented at include:

- A Research-on-Tap Seminar entitled "Towards a Water-Energy-Food Nexus Index" at the University of KwaZulu-Natal's Centre for Water Resources Research on 25 April 2019, in Pietermaritzburg, South Africa,

- A workshop entitled the "Development of the Water-Energy-Food Nexus Index and its application to South Africa and the South African Development Community (SADC): From Theory to Practise" at the Water Research Commission in Pretoria, South Africa, on 10 May 2019,

- A presentation at the 2019 European Climate Change Adaptation Conference in Lisbon, Portugal, on 30 May 2019, entitled the "Development of the Water-Energy-Food Nexus Index and its application to South Africa and SADC",

- A lunchtime seminar at IHE Delft Institute for Water Education, Delft, The Netherlands on 5 June 2019, entitled the "Development of the Water-Energy-Food Nexus Index and its application to South Africa and SADC", and

- A COIN Open Day at the JRC in Ispra, Italy, on 7 June 2019, entitled the "Development of the Water-Energy-Food nexus index and its application to South Africa and SADC".

The outcome of this analysis and stakeholder/expert engagement was that a set of 21 indicators were selected to compose the WEF Nexus Index, which is presented in Figure 3. Adequate data is available for the index to be calculated for 170 nations. The untreated indicator data for the 21 indicators that make up the WEF Nexus Index are presented in Addendum B. The water-access sub-pillar represents SDG 6 (access to basic drinking water and sanitation services) and the degree of Integrated Water Resources Management (IWRM; which is an indicator of good governance in terms of water resources management). 
The energy-access sub-pillar includes both access to electricity (SDG indicator 7.1.1) and two indicators that appertain to the degree of renewable energy consumption (SDG indicator 7.2.1) and implementation, as well as $\mathrm{CO}_{2}$ emissions (which is an indicator of the degree of dependence on fossil fuels). These indicators have been aggregated because SDG 7 appertains to access to affordable, reliable, sustainable and modern energy for all, and not simply 'access to energy'.

The food-access sub-pillar includes, amongst others, SDG indicators 2.1.1 (prevalence of undernourishment), 2.2.1 (percentage of children under five years of age who are stunted) and FAO indicator 4.8 (prevalence of obesity in the adult population). The food-accessibility subpillar includes FAO indicators 1.1 (average dietary energy supply adequacy), 1.2 (average value of food production) and 1.4 (average protein supply), and the cereal yield in kilograms per hectare.

The latest available data (in August 2019) was utilised for the calculation of the WEF Nexus Index, with the reference year varying between indicators, as presented in Appendix A.

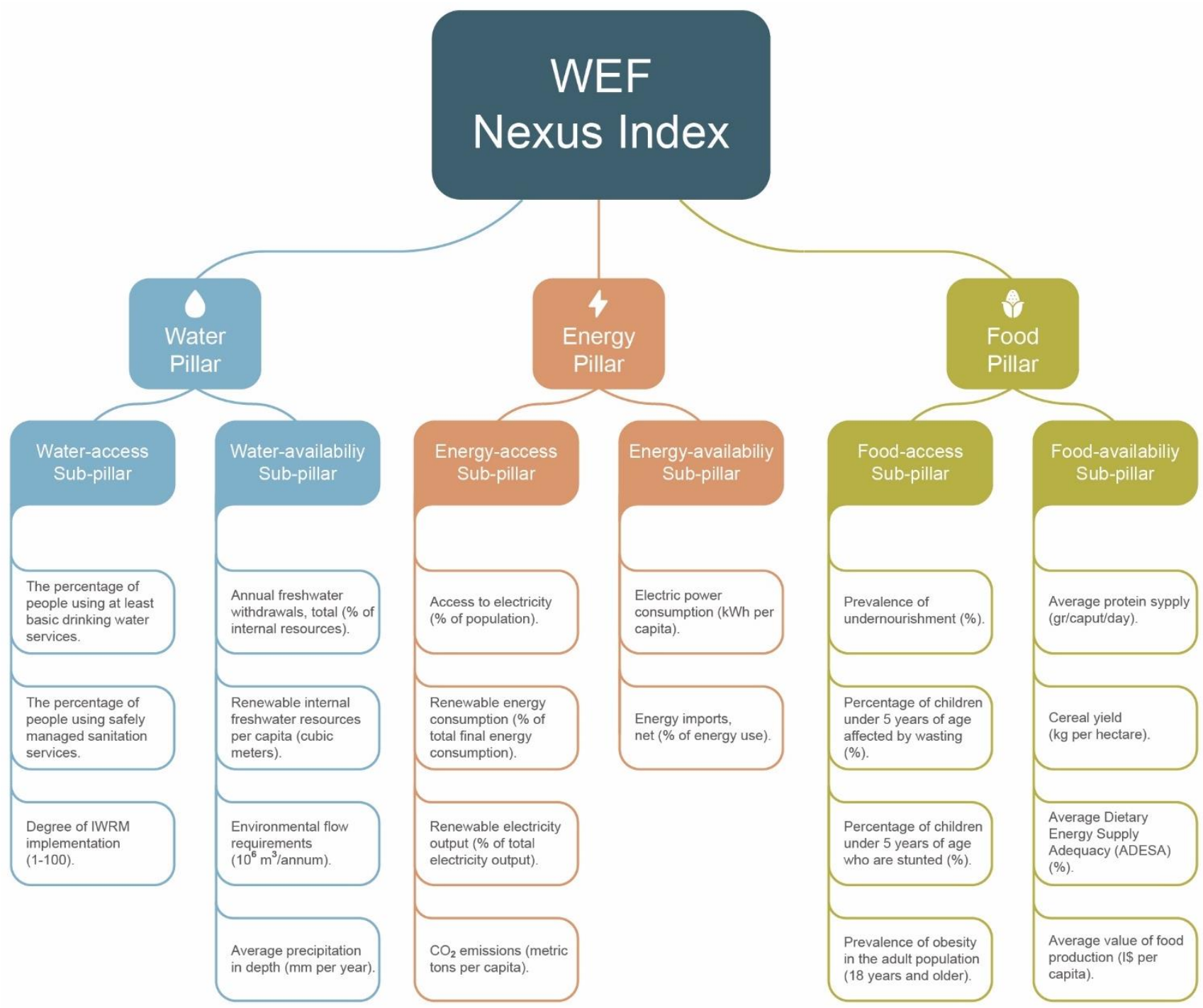

Figure 3: Schematic layout of the WEF Nexus Index, with its constituent pillars, subpillars, and indicators 


\subsection{Data treatment and normalisation}

Following the selection of indicators, missing data were imputed where appropriate or necessary in accordance with the JRC:COIN guidelines. One case of imputation was for levels of undernourishment in high-income countries. Here, average values reported by UNICEF were utilised, e.g. the average prevalence of undernourishment in high-income countries is $1.2 \%$ (Sachs et al. 2018). All indicators were then normalised to transform them into a uniform scale: [0:100] (OECD 2008). This is standard practice in composite indicator construction, since not only are the indicators measured in different units, but their values vary markedly, e.g. the indicator Percentage of children under five years of age who are affected by wasting varies from $0.3 \%$ to $22.7 \%$, whereas the Renewable internal freshwater resources per capita vary from 2.5 to 519265 cubic metres. In this project, the min-max method was utilised to normalise the data (Saisana et al. 2018, Simpson et al. 2020). The COIN Tool was utilised for the calculation of the WEF Nexus Index (Becker et al. 2019). Where there was no data for an indicator, shallow imputation was applied by the COIN Tool, whereby it "calculates the subpillar score by taking the mean only over the indicators that have data" (Becker et al. 2019). This is the same as substituting the missing value with the normalised mean of the other indicators in the aggregation group (e.g. pillar or sub-pillar).

Outliers were treated in particular cases. This practice is necessary since outliers "generally spoil basic descriptive statistics such as the mean, the standard deviation, and correlation coefficient, thus causing misinterpretation" (Saisana et al. 2018). Where the skewness and kurtosis of an indicator's data set exceeded the generally accepted range, i.e. $|<2|$ and $|<3.5|$ respectively, a process of either Winsorisation (where there are five or fewer outliers) or a Boxcox transformation (if the number of outliers exceeds five) was adopted (Saisana et al. 2018). This is described in more detail in Simpson et al. (2020).

\subsection{Weighting and aggregation of indicators}

The sub-pillar scores were obtained by determining the weighted arithmetic average of the indicators in each sub-pillar. Pillar scores were calculated using the arithmetic average of the corresponding sub-pillar scores, and the final index score was an arithmetic average of the pillar scores. Equal weighting was used at the pillar level to preserve the multi-centric philosophy of the WEF nexus approach, such that each resource sector has equal importance (Allouche et al. 2015, Benson et al. 2015, Owen et al. 2018). Given that some sub-pillars contain more indicators than others and the fact that some indicators in a sub-pillar have stronger weightings than others, the final weight of each indicator in the overall index is unequal. The final weights, per aggregation level, are presented in Table $\mathbf{1}$ and Addendum $\mathbf{C}$.

The arithmetic mean was used for aggregation despite its known properties of compensability. Compensability refers to the extent to which a decrease in one indicator can be compensated for by an increase in another indicator. If the indicators are summed, i.e. using the arithmetic mean, there is a higher degree of compensability than if they are multiplied, i.e. using the geometric mean. This is because the latter method 'penalises' lower scores in indicators to a greater extent than the former method. The use of the arithmetic mean to calculate the WEF Nexus Index was, nonetheless, prefered because there is a reasonable degree of substitutability between SDGs and utilising the arithmetic mean is easier to understand than the geometric mean. This method of aggregation was also adopted in the development of the SDG Index (Sachs et al. 2016, Sachs et al. 2018). 


\subsection{Open science and visualisation}

An essential part of this project is the communication of the WEF Nexus Index. Now, more than ever, visualising data in an engaging manner is vital for the acceptance and dissemination of public data, making it more accessible and understandable (Shneiderman 1996, van Wijk 2005). Data visualisation is the discipline that studies how to interpret and understand graphics and charts that represent complex data (Tufte 1983). Its primary design principles have been applied in a set of visualisations compiled in an interactive website associated with the WEF Nexus Index, namely https://www.wefnexusindex.org/.

The website, published to disseminate the WEF Nexus Index, provides data at hierarchical levels. First, it offers a global view of the main index, as well as its three main pillars (water, energy and food), utilising an interactive globe. The globe includes a novel legend that combines a classical colour legend with a strip plot, which graphically presents the distribution of the selected index or pillar.

At the same level of visualisation, and complementary to the globe, are visualisations comprising of glyphs (as presented in Figure 4). These glyphs represent the WEF Nexus Index and its pillars by country. These glyphs can be compared and sorted in order to facilitate a WEF nexus analysis. Further, each country has a dedicated page that provides more details for that nation such as the availability and access sub-pillar values, a radar chart, global rankings, a scatter plot of accessibility and access (which highlights correlations), together with the indicator values themselves.

\section{$4 \quad$ Results}

The WEF Nexus Index was calculated for 170 nations, as presented in the annotated world map in Figure 4 (also refer to the visualisation website associated with the WEF Nexus Index https://www.wefnexusindex.org/). The treated values for these countries are presented in a dashboard in Addendum D. The highest- and lowest-twenty ranking countries for the WEF Nexus Index are shown in Table 2 and Table 3, respectively. The median WEF Nexus Index value is 55, while the average is 54 .

The five Scandinavian countries rank in the top ten (Norway, Sweden, Iceland, Denmark and Finland). These nations are characterised by high levels of service delivery in terms of improved drinking water services, safe sanitation facilities, and access to electricity. They also generally have high levels of renewable freshwater resources with low withdrawal levels, together with relatively high renewable energy output.

While the highest-twenty ranking nations are predominantly developed countries, there are five South American countries and one Asian state (Malaysia) within this list. The five South American countries in the top twenty are Brazil (tenth), Columbia (fourteenth), Paraguay (fifteenth), Argentina (nineteenth) and Uruguay (twentieth).

While no African countries feature in the twenty highest-ranking nations for the WEF Nexus Index, three-quarters of lowest-ranking countries are from Africa. These countries are, however, generally low emitters of $\mathrm{CO}_{2}$ per capita, primarily due to the dearth of proven coal reserves outside of South Africa (Agora 2017), together with relatively low levels of development (although several African nations utilise oil or gas for electricity generation). Within the twenty lowest-ranking nations, Djibouti, Mauritania, Yemen, and South Sudan are from the Middle East and North Africa (MENA) region. The MENA region is characterised by severe water scarcity and a steady transition toward renewable energy (Hoff et al. 2019). 
Table 1: Contribution of indicators, sub-pillars, and pillars to the WEF Nexus Index

\begin{tabular}{|c|c|c|c|c|c|}
\hline Indicator & $\begin{array}{l}\text { Indicator weight } \\
\text { in the index }\end{array}$ & Sub-pillar & $\begin{array}{l}\text { Sub-pillar weight } \\
\text { in the index }\end{array}$ & Pillar & $\begin{array}{l}\text { Pillar wieght } \\
\text { in the index }\end{array}$ \\
\hline 1 & 0.056 & \multirow{4}{*}{$\begin{array}{l}\text { Water- } \\
\text { access }\end{array}$} & & \multirow{7}{*}{ Water } & \multirow{7}{*}{$\begin{array}{l}1 \\
3\end{array}$} \\
\hline 2 & 0.056 & & $\begin{array}{l}1 \\
6\end{array}$ & & \\
\hline 3 & 0.056 & & & & \\
\hline 4 & 0.042 & & & & \\
\hline 5 & 0.042 & \multirow{3}{*}{$\begin{array}{c}\text { Water- } \\
\text { availability }\end{array}$} & \multirow{3}{*}{$\begin{array}{l}1 \\
6\end{array}$} & & \\
\hline 6 & 0.042 & & & & \\
\hline 7 & 0.042 & & & & \\
\hline 8 & 0.083 & & & \multirow{6}{*}{ Energy } & \multirow{6}{*}{$\begin{array}{l}1 \\
3\end{array}$} \\
\hline 9 & 0.028 & Eneray- & 1 & & \\
\hline 10 & 0.028 & access & 6 & & \\
\hline 11 & 0.028 & & & & \\
\hline 12 & 0.083 & \multirow{2}{*}{$\begin{array}{l}\text { Energy- } \\
\text { availability }\end{array}$} & 1 & & \\
\hline 13 & 0.083 & & 6 & & \\
\hline 14 & 0.056 & & & \multirow{8}{*}{ Food } & \multirow{8}{*}{$\begin{array}{l}1 \\
3\end{array}$} \\
\hline 15 & 0.028 & Food- & 1 & & \\
\hline 16 & 0.028 & access & 6 & & \\
\hline 17 & 0.056 & & & & \\
\hline 18 & 0.042 & \multirow{4}{*}{$\begin{array}{l}\text { Food- } \\
\text { availability }\end{array}$} & \multirow{4}{*}{1} & & \\
\hline 19 & 0.042 & & & & \\
\hline 20 & 0.042 & & & & \\
\hline 21 & 0.042 & & & & \\
\hline
\end{tabular}



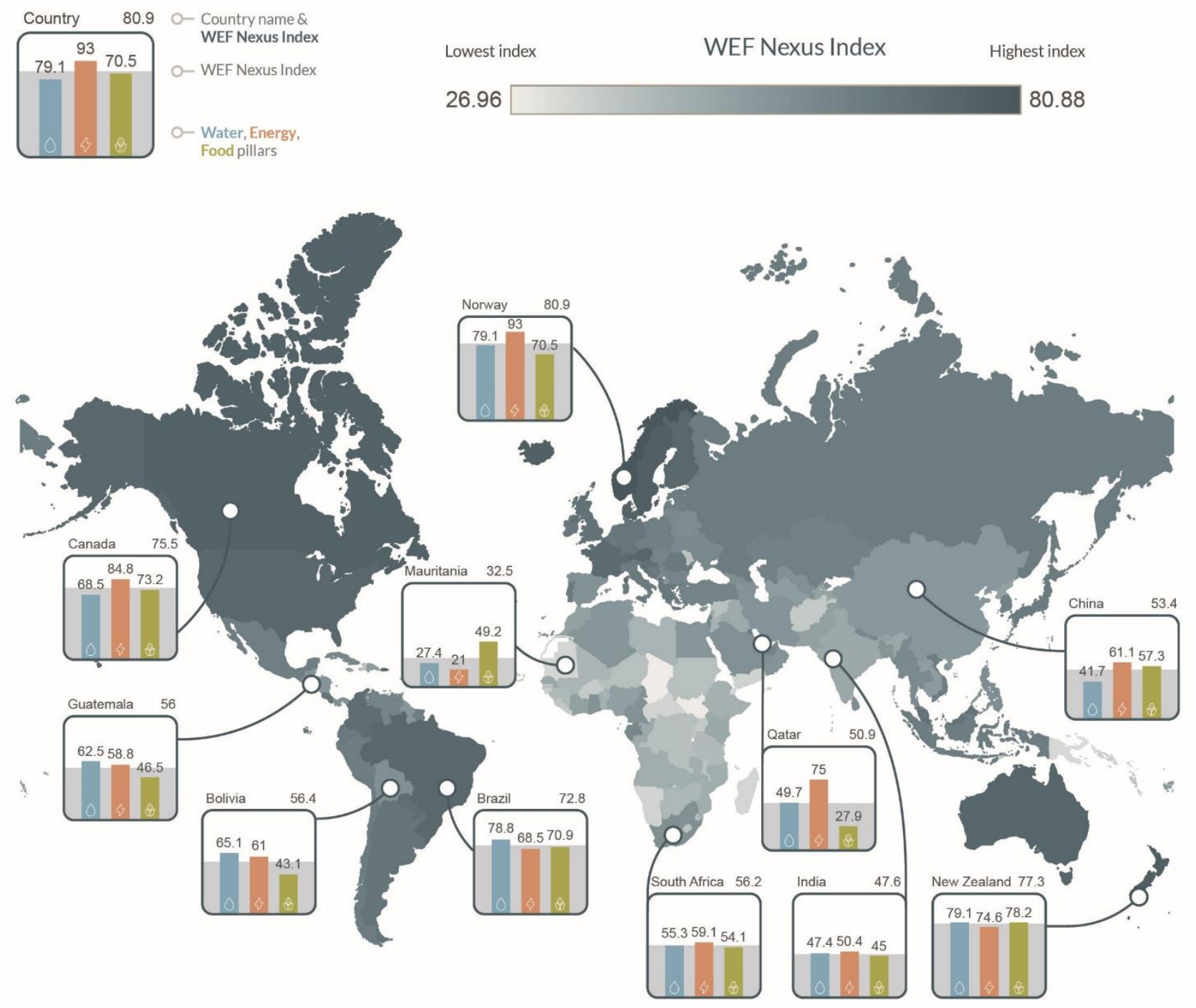

Figure 4: World map indicating the WEF Nexus Index per country (with selected countries featured in glyphs) - see https://www.wefnexusindex.org/ for an interactive website

Mauritania in north-western Africa, for example, has a mean annual precipitation (MAP) of only $92 \mathrm{~mm}$ (less than half of the $10^{\text {th }}$ percentile value for the nations assessed). This nation's annual freshwater withdrawal is more than three times its total internal freshwater resources (337\% and 98.4 cubic metres per capita). The country with the lowest WEF Nexus Index value is the landlocked Central African nation of Chad, with a score of 27.0.

The results of this WEF nexus assessment highlight the stark inequalities in the world between countries that have excellent access to, and availability of, resources, and those that do not. Further, coal and oil have been utilised as a means to develop numerous nations. Many of the countries that have built their wealth on the back of fossil fuel-based energy generation are now steadily transitioning to being low-carbon developed economies. 
Table 2: WEF Nexus Index values for the twenty highest-ranked countries

\begin{tabular}{|c|c|c|c|c|}
\hline & $\begin{array}{c}\text { WEF } \\
\text { Nexus Index }\end{array}$ & $\begin{array}{c}\text { Water } \\
\text { sub-Index }\end{array}$ & $\begin{array}{c}\text { Energy } \\
\text { sub-Index }\end{array}$ & $\begin{array}{c}\text { Food } \\
\text { sub-Index }\end{array}$ \\
\hline Norway & 80.80 & 79.10 & 93.02 & 70.53 \\
\hline New Zealand & 77.29 & 79.12 & 74.58 & 78.17 \\
\hline Sweden & 76.87 & 78.18 & 82.33 & 70.11 \\
\hline Iceland & 76.57 & 79.38 & 93.17 & 57.16 \\
\hline Canada & 75.51 & 68.50 & 84.81 & 73.22 \\
\hline Denmark & 75.32 & 70.64 & 73.53 & 81.80 \\
\hline Australia & 74.10 & 78.55 & 70.89 & 72.87 \\
\hline Austria & 74.06 & 77.85 & 62.64 & 81.69 \\
\hline Finland & 72.83 & 74.16 & 75.97 & 68.35 \\
\hline Brazil & 72.75 & 78.81 & 68.53 & 70.92 \\
\hline USA & 72.67 & 65.40 & 73.33 & 79.28 \\
\hline France & 71.74 & 77.73 & 59.24 & 78.24 \\
\hline Switzerland & 71.19 & 77.01 & 63.67 & 72.88 \\
\hline Colombia & 70.12 & 82.64 & 67.20 & 60.53 \\
\hline Paraguay & 69.99 & 68.97 & 73.78 & 67.21 \\
\hline Croatia & 68.96 & 78.48 & 59.70 & 68.69 \\
\hline United Kingdom & 68.53 & 75.56 & 58.29 & 71.74 \\
\hline Malaysia & 67.79 & 79.37 & 64.06 & 59.94 \\
\hline Argentina & 67.63 & 67.60 & 61.41 & 73.87 \\
\hline Uruguay & 67.52 & 65.93 & 63.74 & 72.89 \\
\hline
\end{tabular}


Table 3: WEF Nexus Index values for the twenty lowest-ranked countries

\begin{tabular}{|c|c|c|c|c|}
\hline & $\begin{array}{c}\text { WEF } \\
\text { Nexus Index }\end{array}$ & $\begin{array}{c}\text { Water } \\
\text { sub-Index }\end{array}$ & $\begin{array}{c}\text { Energy } \\
\text { sub-Index }\end{array}$ & $\begin{array}{c}\text { Food } \\
\text { sub-Index }\end{array}$ \\
\hline Lesotho & 37.93 & 43.68 & 26.52 & 43.60 \\
\hline Malawi & 37.75 & 45.73 & 23.80 & 43.72 \\
\hline Rwanda & 37.62 & 46.25 & 26.23 & 40.37 \\
\hline Uganda & 36.27 & 40.51 & 28.69 & 39.61 \\
\hline Afghanistan & 36.14 & 32.62 & 37.66 & 38.13 \\
\hline Timor-Leste & 36.08 & 43.01 & 24.75 & 40.49 \\
\hline Liberia & 36.03 & 50.40 & 18.57 & 39.10 \\
\hline Burkina Faso & 35.74 & 39.55 & 18.36 & 49.32 \\
\hline Guinea-Bissau & 35.18 & 42.49 & 17.45 & 45.61 \\
\hline Solomon Islands & 35.05 & 36.59 & 24.63 & 43.92 \\
\hline Comoros & 34.31 & 42.64 & 31.14 & 29.13 \\
\hline Yemen, Rep. & 33.98 & 22.92 & 50.74 & 28.28 \\
\hline Namibia & 33.39 & 32.27 & 38.66 & 29.24 \\
\hline Central African & 33.15 & 45.71 & 24.69 & 29.05 \\
\hline Republic & & & & \\
\hline Madagascar & 32.94 & 43.33 & 22.82 & 32.69 \\
\hline Mauritania & 32.54 & 27.40 & 21.02 & 49.22 \\
\hline Djibouti & 32.13 & 36.42 & 21.17 & 38.81 \\
\hline Papua New & 32.00 & 49.04 & 19.36 & 27.61 \\
\hline Guinea & & & & \\
\hline South Sudan & 26.97 & 37.17 & 36.79 & 6.95 \\
\hline Chad & 6.96 & 29.94 & 16.10 & 34.84 \\
\hline
\end{tabular}


The WEF Nexus Index is a quantitative measure of resource security that relates to water, energy and food. It provides an entry point for the evaluation of the status of a nation in terms of integrated resource management. A WEF Nexus Index value is, therefore, an indication of a country's level of equitable access to, and availability of, these three critical resources. These assessments should be combined with other quantitative and qualitative research to broaden the analysis beyond the 'reach' of the constituent indicators (which is a limitation of a composite indicator), as presented in Figure 1.

To demonstrate how the WEF Nexus Index can be utilised as a catalyst and foundation for nexus analyses, it has been applied to a case study from the developing world, namely South Africa. This assessment demonstrates the value and relevance of the underlying pillars, sub-pillars and indicators. South Africa, with an index value of 56.2, ranked $72^{\text {nd }}$ out of the 170 nations with sufficient data to calculate the WEF Nexus Index, as presented in Figure 5 and Table 4. Of the 49 African nations in this study, South Africa ranked $2^{\text {nd }}$ behind Gabon, which has an index value of 59.4. The water, energy, and food pillar values for South Africa are 55.3, 59.1 and 51.1, respectively.

While access to basic drinking water and safely managed sanitation services are relatively high, given South Africa's history of inequality in terms of service delivery, water availability is decidedly stressed (Mabhaudhi et al. 2018). Significant effort and focussed policies are, therefore, necessary to prudently manage South Africa's scarce water resources. Since the end of Apartheid, the levels of access to at least basic drinking water (87.4\% in 2015) and safely managed sanitation services $(73.1 \%$ in 2015$)$ have increased significantly in South Africa (World Bank 2018). These values, together with the degree of IWRM implementation, at $65.5 \%$, yield the highest sub-pillar value for this nation. Much work, however, remains in South Africa, mainly because it still exhibits extreme levels of income inequality, with one of the highest Gini coefficients globally (Hundenborn et al. 2019). This disparity is evidenced by $4 \%$ of the population in some provinces still utilising the "bucket toilet system", while nationally $4 \%$ of the populace practice open defecation (StatsSA 2016).

The water-availability sub-pillar is, in contrast, the second-lowest for South Africa. This is partly due to this nation receiving approximately half the global mean annual rainfall (Pitman 2011, DWA 2016). South Africa yields less available freshwater per capita than nations that are generally considered to be significantly drier, such as Namibia and Botswana (DWA 2013). South Africa's renewable internal freshwater resources were 821 cubic metres per capita in 2014 (World Bank 2018), which is less than the $20^{\text {th }}$ percentile for the 170 nations assessed.

In terms of annual freshwater withdrawals, South Africa extracted $34.6 \%$ of its internal resources in 2014 (World Bank 2018), which is marginally less than the $80^{\text {th }}$ percentile for the countries included in this study. In this regard, Colvin et al. (2011) explain that "More than $95 \%$ of the usable water yield has been allocated for the ecological reserve, to meet international obligations and to supply water for domestic, industrial and agricultural use."

In terms of 'water for food', the elevated water stress and allocation levels severely limit opportunities for boosting food production through increasing irrigated agriculture. Land is also a constraint in this regard, with only $3 \%$ of South Africa's surface area being considered high potential arable land (Collett 2013). In terms of one facet of 'water for energy' (other aspects of this nexus will be discussed later in this article), South Africa has minimal hydropower potential and development (Conway et al. 2015).

While South Africa's increase in access to electricity since 1990 has been marked (World Bank 2018), with $84 \%$ of the population having access to electricity in 2016 (as opposed to $59.3 \%$ in 1990), the same cannot be said about the nation's transition to renewable energy. In contrast to the lack of coal reserves in other African countries, South Africa has $95 \%$ of the continent's proven coal reserves 
(Agora 2017). It is the seventh-largest producer of coal internationally (International Energy Agency 2017). In 2014 it emitted nine tonnes of $\mathrm{CO}_{2}$ per capita, and three years later was the fourteenth highest nett emitter of $\mathrm{CO}_{2}$ globally (Fleming 2019).

In 2014, South Africa generated about 253 TWh of power, almost $92 \%$ of which was produced through burning coal (Agora 2017). Based on long-term contracts South Africa will probably continue to depend on coal-fired power stations for the next three to five decades (Delport et al. 2015). As a result, South Africa's renewable electricity output was only $2.3 \%$ of the total electricity output in 2015 (World Bank 2018).

Trade-offs associated with fossil-fuel-based energy security (and the associated coal mines) in South Africa include, inter alia, human health, air pollution, water pollution, loss of high-potential agricultural land and loss of biodiversity (Colvin et al. 2011, BFAP 2012, Lodewijks et al. 2013, CER 2016, Solomons 2016, CER 2018, Forrest and Loate 2018, Greenpeace 2018, CER 2019, Fleming 2019, Simpson et al. 2019). A crucial consideration in integrated resource management is that the attainment of resource security for one sector should not compromise an interdependent sector (Simpson and Berchner 2017). For national government, who must wear many 'hats', they are often 'between a rock and a hard place', This is because there are conflicting trade-offs associated with an accelerated transition to a low-carbon economy. These include sector-related jobs (as well as secondary and tertiary employment spawned by the coal and power industries) and export revenue (Delport et al. 2015, Webb 2015, Simpson et al. 2019).

In terms of 'water for energy' power generation utilises approximately $2 \%$ of the available freshwater in the country (DWA 2013). Eskom, the state-owned utility stands at the front of the 'queue' in terms of water allocation. This is because it is guaranteed supply as the only 'strategic' water user under the National Water Act 36 of 1998 (Olsson 2013). Not only does the power-generation industry require water at the highest level of assurance, but it also requires excellent water quality (WWF 2011). In terms of 'energy for food' and 'energy for water', electricity supply to the national grid has been interrupted by 'load shedding' (rolling blackouts) at regular intervals over the last twelve years, which has had a significant negative impact on the economy (World Bank 2017).

The energy-accessibility sub-pillar includes two indicators, i.e. electric power consumption and nett energy imports. In terms of the first of these, South Africa's populace consumed $4198 \mathrm{kWh}$ per capita in 2014 (World Bank 2018). This value is less than the $67^{\text {th }}$ percentile for the 170 nations assessed. For the same base year, South Africa was a nett exporter of energy.

The second-highest-ranking sub-pillar for South Africa is the food access sub-pillar. The prevalence of undernourishment in South Africa is $6.1 \%$, which is below the median value for the countries included in this study, i.e. 6.5\% (World Bank 2018). While the percentage of children under five years of age who are affected by wasting is $2.5 \%$ (slightly less than the $40^{\text {th }}$ percentile), $27.4 \%$ are stunted, i.e. marginally less than the $70^{\text {th }}$ percentile value. Meanwhile, the prevalence of obesity in the adult population, eighteen years or older, is $27 \%$, which exceeds the $80^{\text {th }}$ percentile. These values emphasise the profound inequalities that exist among South Africa's citizens.

Maize is South Africa's major grain crop, providing the staple diet for the bulk of the population. About half of the maize produced is used for animal feed, 70\% of which is for poultry (WWF 2010, BFAP 2018). Traditionally, South Africa was a nett exporter of food, but it has recently become a nett importer due to agricultural production not increasing at the same rate as population growth (Bazilian et al. 2011). Food production could be further jeopardised by the loss of high potential agricultural land due to mining and urbanisation, particularly in the province of Mpumalanga (Simpson et al. 2019). 


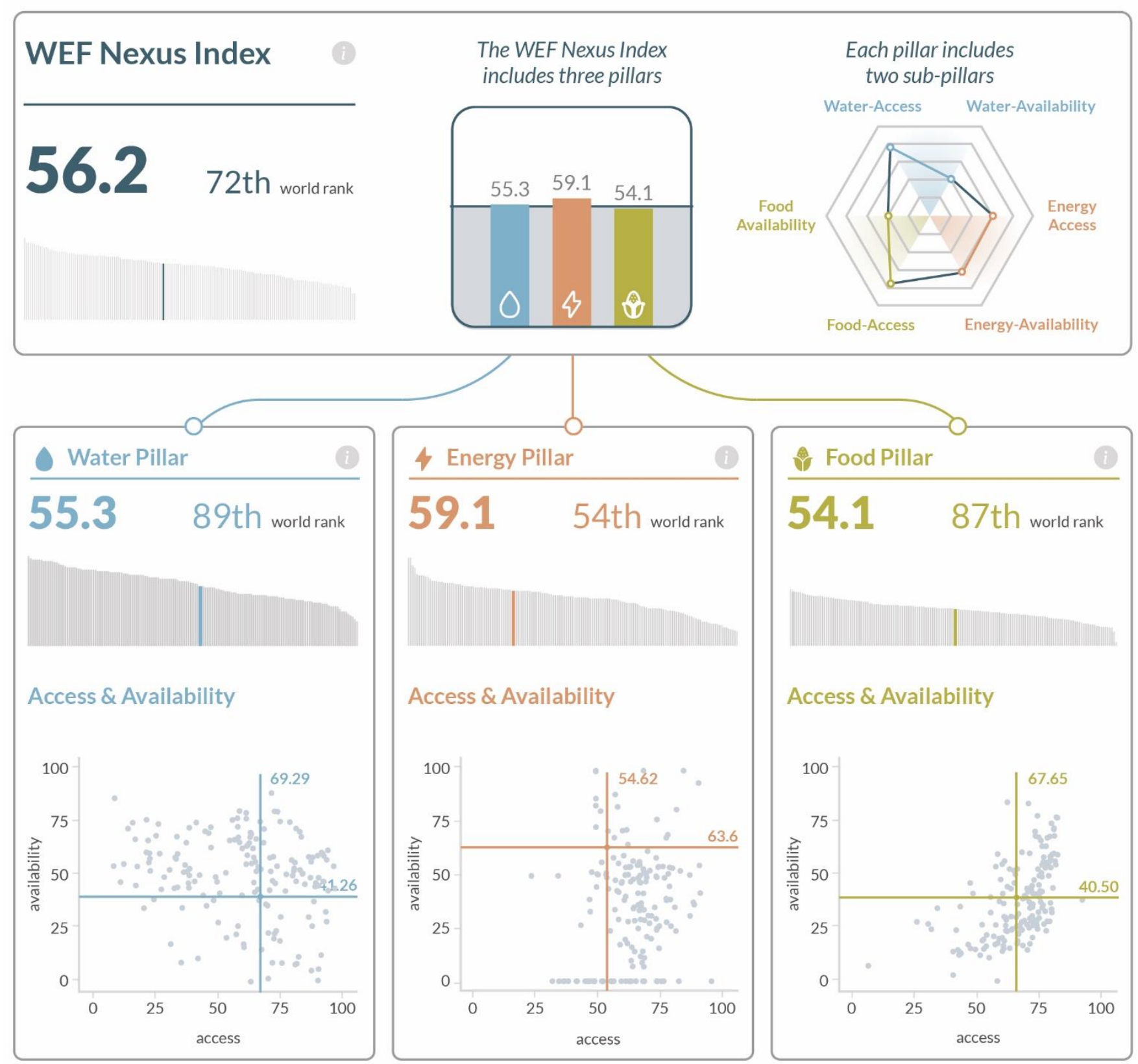

Figure 5: Country data for case study nation, South Africa, indicating WEF Nexus Index, pillar, sub-pillar values and ranking

Alarmingly, the lowest ranking sub-pillar is the food-availability sub-pillar, with a value of 40.5 . Three of the constituent indicators, namely average protein supply, average dietary energy supply adequacy and the average value of food production, have values that approximate the median value for the nations included in this study. The cereal yield, at 3810 kilograms per capita per hectare (World Bank 2018), exceeds the $60^{\text {th }}$ percentile value for the 170 countries included in this study. The low sub-pillar value, together with the relatively average rank of South Africa in terms of the availability of food, indicates that this is an issue of global concern. This conclusion is confirmed by the FAO (2018), who state that 
"Feeding a global population that is expected to reach 9.8 billion people by 2050 will require a 60 per cent increase in food production (compared with 2012 levels) and substantial avoidance of food losses along value chains."

\section{Table 4: Indicators (and values) that constitute the WEF Nexus Index}

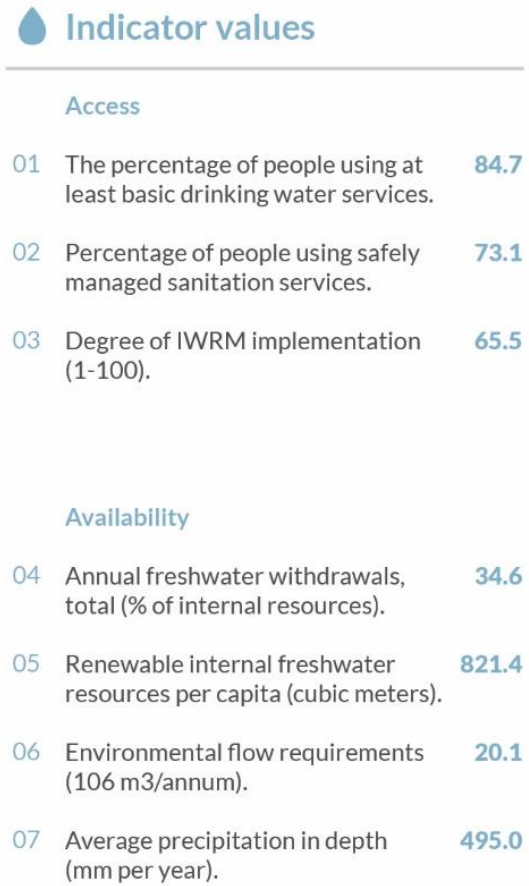

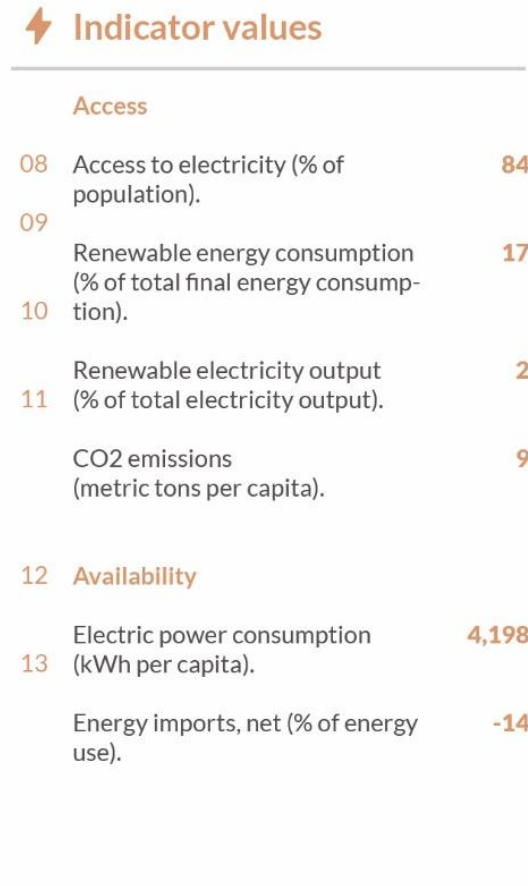

\begin{tabular}{|c|c|c|}
\hline & Access & \\
\hline 14 & $\begin{array}{l}\text { Prevalence of undernourishment } \\
\text { (\%). }\end{array}$ & 6 \\
\hline 15 & $\begin{array}{l}\text { Percentage of children under } 5 \\
\text { years of age affected by wasting } \\
\text { (\%). }\end{array}$ & 3 \\
\hline 17 & $\begin{array}{l}\text { Percentage of children under } 5 \\
\text { years of age who are stunted (\%). }\end{array}$ & 27 \\
\hline & $\begin{array}{l}\text { Prevalence of obesity in the adult } \\
\text { population (18 years and older). }\end{array}$ & 27 \\
\hline 18 & Availability & \\
\hline 19 & $\begin{array}{l}\text { Average protein supply } \\
\text { (gr/caput/day). }\end{array}$ & 83 \\
\hline & Cereal yield (kg per hectare). & 3,810 \\
\hline 21 & $\begin{array}{l}\text { Average Dietary Energy Supply } \\
\text { Adequacy (ADESA) (\%). }\end{array}$ & 123 \\
\hline & $\begin{array}{l}\text { Average value of food production } \\
\text { (I\$ per capita). }\end{array}$ & 229 \\
\hline
\end{tabular}

\section{Conclusions}

This study has yielded a country-level composite indicator related to the WEF nexus that highlights water-, energy- and food-related issues. It provides a quantitative means of ascertaining 170 different nation's status in terms of integrated resource management, utilising the WEF nexus as a lens. It also provides an opportunity for comparing a nation's status with other countries, whether from the same region (e.g. SADC or MENA), at a similar level (i.e. developed or developing), or by assessing a nation relative to a specific country included in the study (high or low ranking). By providing a quantitative measure of the WEF nexus, the index provides a summary and entry point to the complex dataset that underlies it (refer to Figure 1). A more detailed analysis of the constituent indicators will provide the researcher, policy-maker or decision-maker with insights and prompts in terms of where interventions and investments are necessary. Based on the constituent indicators, the WEF Nexus Index is a function of the national resource base (e.g. land, water and fossil fuels), governance and service delivery, and the degree of energy transition (to renewable sources), consumption and self-sufficiency.

WEF nexus assessments in the decade leading up to the 2030 SDG target year must be more comprehensive. Qualitative studies should be conducted in parallel with quantitative assessments. There is no one-size-fits-all method for integrated resource management utilising the WEF nexus approach. Instead, the methodology must be tailored for each unique situation, and the WEF Nexus Index can be a catalyst and entry-point for such studies, as demonstrated through the application of the index to South Africa. By evaluating a subset/nexus of the SDGs, the index is complementary to the 
SDGs. But as with the SDGs, this nexus study suffers from a shortage of 'integrated' indicators. This gap could be addressed in the future as new indicators are developed. The WEF Nexus Index is not a 'silver bullet' that will solve all the significant development and environmental challenges facing humanity. This approach can, however, be added to the sustainability toolbox that is being utilised to engineer 'the future we want'.

\section{$7 \quad$ References}

Abdullaev, I., and Rakhmatullaev, S. 2016. Setting up the agenda for water reforms in Central Asia: Does the nexus approach help? Environmental Earth Sciences 75. doi: 10.1007/s12665-0165409-8

Abeyasekera, S. 2003. Multivariate methods for index construction. Household Surveys in Developing and Transition Countries: Design, Implementation and Analysis.

Agora. 2017. Flexibility in thermal power plants - With a focus on existing coal-fired power plants. Agora Energiewende, Berlin, Germany. Report number: 115/04-S-2017/EN www.agoraenergiewende.de

Albrecht, T. R., Crootof, A., and A., S. C. 2018. The Water-Energy-Food Nexus: A systematic review of methods for nexus assessment. Environmental Research Letters 13. doi: 10.1088/17489326/aaa9c6

Allouche, J., Middleton, C., and Gyawali, D. 2015. Technical Veil, Hidden Politics: Interrogating the Power Linkages behind the Nexus. Water Alternatives-an Interdisciplinary Journal on Water Politics and Development 8:610-626.

Allouche, J., Middleton, C., and Gyawali, D. 2019. The Water-Energy-Food Nexus: Power, Politics, and Justice. Routledge, Abingdon, Oxon.

Bazilian, M., Rogner, H., Howells, M., Hermann, S., Arent, D., Gielen, D., Steduto, P., Mueller, A., Komor, P., Tol, R. S. J., and Yumkella, K. K. 2011. Considering the energy, water and food nexus: Towards an integrated modelling approach. Energy Policy 39:7896-7906. doi: 10.1016/j.enpol.2011.09.039

Becker, W., Benavente, D., Dominguez Torreiro, M., Moura, C., Neves, A., Saisana, M., and Vertesy, D. 2019. COIN Tool User Guide. Publications Office of the European Union, Luxembourg.

Beddington, J. 2009. Food, energy, water and the climate: A perfect storm of global events? , Government Office for Science, London, England.

Beddington, J. 2010. Food security: contributions from science to a new and greener revolution. Philosophical Transactions of the Royal Society B:61-71. 10.1098/rstb.2009.0201

Belinskij, A. 2015. Water-Energy-Food Nexus within the Framework of International Water Law. Water 7:5396-5415. doi: 10.3390/w7105396

Benson, D., Gain, A. K., Rouillard, J., and Giupponi, C. 2017. Governing for the Nexus. Pages 77-88 Water-Energy-Food Nexus. John Wiley \& Sons, Inc.

Benson, D., Gain, A. K., and Rouillard, J. J. 2015. Water Governance in a Comparative Perspective: From IWRM to a 'Nexus' Approach? Water Alternatives-an Interdisciplinary Journal on Water Politics and Development 8:756-773. 
BFAP. 2012. Evaluating the Impact of Coal Mining on Agriculture in the Delmas, Ogies and Leandra Districts: A Focus on Maize Production. Bureau for Food and Agricultural Policy, Pretoria, South Africa. http://www.bfap.co.za

BFAP. 2018. BFAP Baseline Agricultural outlook 2018-2027.

Brouwer, F., Anzaldi, G., Laspidou, C., Munaretto, C., Schmidt, G., Strosser, P., Sušnik, J., and Vamvakeridou-Lyroudia, L. 2018. Commentary To SEI Report 'Where is the added value? A review of the Water-Energy-Food Nexus Literature'. SIM4NEXUS, Wageningen, Netherlands.

Cairns, R., and Krzywoszynska, A. 2016. Anatomy of a buzzword: The emergence of 'the waterenergy-food nexus' in UK natural resource debates. Environmental Science \& Policy 64:164170. doi: 10.1016/j.envsci.2016.07.007

CER. 2016. ZERO HOUR: Poor Governance of Mining and the Violation of Environmental Rights in Mpumalanga. Centre for Environmental Rights, Cape Town, South Africa. www.cer.org.za

CER. 2018. Water costs, impacts of coal-fired power grossly underestimated in electricity planning. Centre for Environmental Rights.

CER. 2019. The Truth about Mpumalanga Coal Mines Failure to Comply with their Water Use Licences.

Collett, A. 2013. The impact of effective (geo-spatial) planning on the agricultural sector. South African Surveying and Geomatics Indaba 22-24 July 2013.

Colvin, C., Burns, A., Schachtschneider, K., Maherry, A., Charmier, J., and de Wit, M. 2011. Coal and Water Futures in South Africa The case for protecting headwaters in the Enkangala grasslands. WWF-South Africa:82.

Conway, D., van Garderen, E. A., Deryng, D., Dorling, S., Krueger, T., Landman, W., Lankford, B., Lebek, K., Osborn, T., Ringler, C., Thurlow, J., Zhu, T. J., and Dalin, C. 2015. Climate and southern Africa's water-energy-food nexus. Nature Climate Change 5:837-846. doi: $10.1038 /$ nclimate 2735

De Laurentiis, V., Hunt, D. V. L., and Rogers, C. D. F. 2016. Overcoming Food Security Challenges within an Energy/Water/Food Nexus (EWFN) Approach. Sustainability 8. doi: $10.3390 /$ su8010095

de Loë, R. C., and Patterson, J. J. 2017. Rethinking Water Governance: Moving Beyond Water-Centric Perspectives in a Connected and Changing World. Natural Resources Journal 57:75-99.

de Vito, R., Portoghese, I., Pagano, A., Fratino, U., and Vurro, M. 2017. An index-based approach for the sustainability assessment of irrigation practice based on the water-energy-food nexus framework. Advances in Water Resources 110:423-436. https://doi.org/10.1016/j.advwatres.2017.10.027

Delport, M., Davenport, M., van der Burgh, G., Meyer, F., Vink, N., Vermeulen, N., Davids, T., Blignaut, J., van der Walt, S., Truter, W., Pienaar, M., Solomon, M. H., Ottermann, A., and Blecher, G. 2015. The Balance of Natural Resources: Understanding the Long Term Impact of Mining on Food Security in South Africa. Bureau for Food and Agricultural Policy, Pretoria, South Africa.

DWA. 2013. National Water Resources Strategy: Water for an Equitable and Sustainable Future. Department of Water Affairs. 
Esty, D. C., Levy, M. A., Srebotnjak, T., and de Sherbinin, A. 2005. 2005 Environmental Sustainability Index: Benchmarking National Environmental Stewardship. Yale Center for Environmental Law \& Policy, New Haven, Connecticut.

FAO. 2018. Water-Energy-Food Nexus for the Review of SDG 7. Food and Agriculture Organization.

Fleming, S. 2019. Chart of the day: These countries create most of the world's CO2 emissions. url: https://www.weforum.org/agenda/2019/06/chart-of-the-day-these-countries-create-most-ofthe-world-s-co2-emissions/. World Economic Forum, Date accessed: 17 Jun 2019.

Forrest, K., and Loate, L. 2018. Power and Accumulation Coal Mining, Water and Regulatory Failure. The Extractive Industries and Society 5:154-164.

Galaitsi, S., Veysey, J., and Huber-Lee, A. 2018. Where is the added value? A review of the waterenergy-food nexus literature. Stockholm Environmental Institute, Massachusetts.

Gallagher, L., Dalton, J., Bréthaut, C., Allan, T., Bellfield, H., Crilly, D., Cross, K., Gyawali, D., Klein, D., Laine, S., LeFlaive, X., Li, L., Lipponen, A., Matthews, N., Orr, S., Pittock, J., Ringler, C., Smith, M., Tickner, D., von Schlippenbach, U., and Vuille, F. 2016. The critical role of risk in setting directions for water, food and energy policy and research. Current Opinion in Environmental Sustainability 23:12-16. doi: 10.1016/j.cosust.2016.10.002

Greenpeace. 2018. New satellite data reveals the world's largest air pollution hotspot is Mpumalanga - South Africa. url: http://www.greenpeace.org/africa/.

Hoff, H. 2011. Understanding the Nexus. Background Paper for the Bonn2011 Conference: The Water, Energy and Food Security Nexus. Stockholm Environment Institute, Stockholm.

Hoff, H., Alrahaife, S. A., El Hajj, R., Lohr, K., Mengoub, F. E., Farajalla, N., Fritzsche, K., Jobbins, G., Özerol, G., Schultz, R., and Ulrich, A. 2019. A Nexus Approach for the MENA Region From Concept to Knowledge to Action. Frontiers in Environmental Science 7. doi: 10.3389/fenvs.2019.00048

Hundenborn, J., Woolard, I., and Jellema, J. 2019. The effect of top incomes on inequality in South Africa. . International Tax and Public Finance 26:1018-1047. doi: 10.1007/s10797-018-95299

International Energy Agency. 2017. Coal information: Overview statistics. International Energy Agency. https://webstore.iea.org/coal-information-2017-overview

Jha, R., and Murthy, K. V. B. 2003. A Critique of the Environmental Sustainability Index. Australian National University Division of Economics Working Paper.

Liu, J., Yang, H., Cudennec, C., Gain, A. K., Hoff, H., Lawford, R., Qi, J., de Strasser, L., Yillia, P. T., and Zheng, C. 2017. Challenges in operationalizing the water-energy-food nexus. Hydrological Sciences Journal-Journal Des Sciences Hydrologiques 62:1714-1720. 10.1080/02626667.2017.1353695

Lodewijks, H., Beukes, J., Oberholster, P., Hill, L., Dabrowski, J., Wessels, P., and Cogho, V. 2013. Risk Assessment of Pollution in Surface Waters of the Upper Olifants River System: Implications for Aquatic Ecosystem Health and the Health of Human Users of Water - Summary Report: 2009 - 2013. Olifants River Forum, Mpumalanga, South Africa.

Mabhaudhi, T., Simpson, G. B., Badenhorst, J., Mohammed, M., Motongera, T., Senzanje, A., and Jewitt, G. 2018. Assessing the State of the Water-Energy-Food (WEF) Nexus in South Africa. Water Research Commission, Pretoria, South Africa. 
McGrane, S. J., Acuto, M., Artioli, M., Chen, P.-Y., Comber, R., Cottee, J., Farr-Wharton, G., Green, N., Helfgott, A., Larcom, S., McCann, J. A., O’Reilly, P., Salmoral, G., Scott, M., Todman, L. C., van Gevelt, T., and Yan, X. 2018. Scaling the nexus: Towards integrated frameworks for analysing water, energy and food. The Geographical Journal:1-13. DOI: 10.1111/geoj.12256

Meadows, D. H., Meadows, D. L., Randers, J., and Behrens III, W. W. 1972. The Limits to Growth. Universe Books, New York.

Mohtar, R. H., and Daher, B. 2012. Water, Energy, and Food: The Ultimate Nexus. Second Edition edition. Taylor \& Francis.

Muller, M. 2015. The 'Nexus' As a Step Back towards a More Coherent Water Resource Management Paradigm. Water Alternatives-an Interdisciplinary Journal on Water Politics and Development 8:675-694.

National Intelligence Council. 2012. Global Trends 2030: Alternative Worlds. National Intelligence Council, USA.

OECD. 2008. Handbook on Constructing Composite Indicators: Methodology and User Guide. Organisation for Economic Co-operation and Development.

Olsson, G. 2013. Water, energy and food interactions: Challenges and opportunities. Frontiers of Environmental Science \& Engineering 7:787-793. doi: 10.1007/s11783-013-0526-z

Owen, A., Scott, K., and Barrett, J. 2018. Identifying critical supply chains and final products: An input-output approach to exploring the energy-water-food nexus. Applied Energy 210:632-642. 10.1016/j.apenergy.2017.09.069

Ringler, C., Bhaduri, A., and Lawford, R. 2013. The nexus across water, energy, land and food (WELF): potential for improved resource use efficiency? Current Opinion in Environmental Sustainability 5:617-624. doi: 10.1016/j.cosust.2013.11.002

Rockstrom, J., Steffen, W., Noone, K., Persson, A., F. S. Chapin, I., Lambin, E., Lenton, T. M., Scheffer, M., Folke, C., Schellnhuber, H., Nykvist, B., Wit, C. A. D., Hughes, T., Leeuw, S. v. d., Rodhe, H., Sorlin, S., Snyder, P. K., Costanza, R., Svedin, U., Falkenmark, M., Karlberg, L., Corell, R. W., Fabry, V. J., Hansen, J., Walker, B., Liverman, D., Richardson, K., Crutzen, P., and Foley, J. 2009. Planetary Boundaries: Exploring the Safe Operating Space for Humanity. Ecology and Society 14:32.

Sachs, J., Schmidt-Traub, G., Kroll, C., Durand-Delacre, D., and Teksoz, K. 2016. SDG Index \& Dashboards - Global Report. New York: Bertelsmann Stiftung and Sustainable Development Solutions Network (SDSN).

Sachs, J., Schmidt-Traub, G., Kroll, C., Lafortune, G., and Fuller, G. 2018. SDG Index and Dashboards Report 2018: Global Responsibilities - Implementing The Goals. Bertelsmann Stiftung and Sustainable Development Solutions Network.

Sachs, J., Schmidt-Traub, G., Kroll, C., Lafortune, G., and Fuller, G. 2019. Sustainable Development Report 2019. New York.

Saisana, M., Alberti, V., Alvarez, M., Becker, W., Caperna, G., Cocco, C., Damioli, G., De Pedraza, P., Del Sorbo, M., D’Hombres, B., Dominguez-Torreiro, M., Montalto, V., Moura, C., Neves, A., Norlen, H., Panella, F., Papadimitriou, E., and Vertesy, D. 2018. 16th JRC Annual Training on Composite Indicators and Scoreboards. Joint Research Centre: Competence Centre on Composite Indicators and Scoreboards, Ispra, Italy. 
Salam, P. A., Pandey, V. P., Shrestha, S., and Anal, A. K. 2017. The Need for the Nexus Approach. Pages 1-10 Water-Energy-Food Nexus: Principles and Practices. John Wiley \& Sons, Inc.

Segnestam, L. 2002. Indicators of Environment and Sustainable Development: Theories and Practical Experience. The World Bank Environment Department.

Shneiderman, B. 1996. The Eyes Have It: A Task by Data Type Taxonomy for Information Visualizations. Proceedings 1996 IEEE Symposium on Visual Languages. doi: 10.1109/VL.1996.545307

Simpson, G., and Berchner, M. 2017. Measuring integration - towards a water-energy-food nexus index. The Water Wheel:22-23.

Simpson, G. B., Badenhorst, J., Berchner, M., Jewitt, G. P. W., and Davies, E. 2019. Competition for Land: The Water-Energy-Food Nexus and Coal Mining in Mpumalanga Province, South Africa. Frontiers in Environmental Science 7:1-12. doi: 10.3389/fenvs.2019.00086

Simpson, G. B., and Jewitt, G. P. W. 2019a. The Development of the Water-Energy-Food Nexus as a Framework for Achieving Resource Security: A Review. Frontiers in Environmental Science 7:1-9. 10.3389/fenvs.2019.00008

Simpson, G. B., and Jewitt, G. P. W. 2019b. The water-energy-food nexus in the anthropocene: Moving from 'nexus thinking' to 'nexus action'. Current Opinion in Environmental Sustainability 40:117-123. doi: 10.1016/j.cosust.2019.10.007

Simpson, G. B., Jewitt, G. P. W., and Badenhorst, J. 2020. The Water-Energy-Food Nexus Index and its application to South Africa and the Southern African Development Community. WRC Report no. 2959/1/19, Water Research Commission, Pretoria. ISBN No 978-0-6392-0113-9 http://wrcwebsite.azurewebsites.net/wp-content/uploads/mdocs/2959_final.pdf

Solomons, I. 2016. Mpumalanga paying huge enviro price owing to poor regulation by govt departments - report. Mining Weekly.

StatsSA. 2016. Water and Sanitation: In-depth analysis of the General Household Survey 2002-2015 and Community Survey 2016 data. Statistics South Africa: GHS Series Volume VIII:106.

Steffen, W., Rockstrom, J., Richardson, K., Lenton, T. M., Folke, C., Liverman, D., Summerhayes, C. P., Barnosky, A. D., Cornell, S. E., Crucifix, M., Donges, J. F., Fetzer, I., Lade, S. J., Scheffer, M., Winkelmann, R., and Schellnhuber, H. J. 2018. Trajectories of the Earth System in the Anthropocene. Proceedings of the National Academy of Sciences of the United States of America 115:8252-8259. 10.1073/pnas.1810141115

Sullivan, C. 2002. Calculating a Water Poverty Index. World Development 30:1195-1210.

Sušnik, J. 2018. Data-driven quantification of the global water-energy-food system. Resources, Conservation \& Recycling 133:179-190. doi: 10.1016/j.resconrec.2018.02.023

Transparency International. 2018. Corruption Perceptions Index $2018 . \quad$ url: https://www.transparency.org/cpi2018, Date accessed: 20 September 2019.

Tufte, E. 1983. The Visual Display of Quantitative Information. Graphics Press.

UN Water. 2018. Sustainable Development Goal 6: Synthesis Report on Water and Sanitation. United Nations, New York, USA.

van Wijk, J. 2005. The Value of Visualization. . IEEE Visualization 5. doi: 10.1109/VISUAL.2005.1532781 
Waas, T., Hugé, J., Block, T., Wright, T., Benitez-Capistros, F., and Verbruggen, A. 2014. Sustainability Assessment and Indicators: Tools in a Decision-Making Strategy for Sustainable Development. Sustainability 6:5512-5534. 10.3390/su6095512

Webb, M. 2015. Coal 2015: A review of South Africa’s Coal Sector. Creamer Media.

Weitz, N., Strambo, C., Kemp-Benedict, E., and Nilsson, M. 2017. Closing the governance gaps in the water-energy-food nexus: Insights from integrative governance. Global Environmental Change-Human and Policy Dimensions 45:165-173. 10.1016/j.gloenvcha.2017.06.006

Wendling, Z. A., Emerson, J. W., Esty, D. C., Levy, M. A., and de Sherbinin, A. 2018. 2018 Environmental Performance Index. New Haven, CT. New Haven, Connecticut.

Wichelns, D. 2017. The water-energy-food nexus: Is the increasing attention warranted, from either a research or policy perspective? Environmental Science \& Policy 69:113-123. doi: 10.1016/j.envsci.2016.12.018

Wong, J. L. 2010. The Food-Energy-Water Nexus. Harvard Asia Quarterly 12:15-19.

World Bank. 2017. Modeling the Water-Energy Nexus: How Do Water Constraints Affect Energy Planning in South Africa? World Bank Group.

World Bank. 2018. Indicators. Data. url: http://data.worldbank.org/indicator/, Date accessed: 1 March

World Economic Forum. 2011. Water Security: The Water-Energy-Food-Climate Nexus. World Economic Forum, Washington, USA.

World Economic Forum. 2018. The Global Risks Report 2018 - 13th Edition. World Economic Forum, Geneva.

WWF. 2010. Agriculture: Facts \& Trends South Africa.

WWF. 2011. Coal and Water Futures in South Africa: A case for conserving headwaters in Enkangala Grasslands. Media Backgrounder:1-14.

WWF and SABMiller. 2014. The Water-Food-Energy Nexus: Insights into Resilient Development.20.

\section{Conflict of Interest}

Gareth Simpson and Jessica Badenhorst are employed by the company Jones \& Wagener (Pty) Ltd. Pere Rovira and Victor Pascual are employed by the company OneTandem. All other authors declare no competing interests.

\section{$9 \quad$ Author Contributions}

Gareth Simpson wrote the manuscript in consultation with Professor Graham Jewitt, who supervised the project. William Becker and Ana Neves provided input into the development of the WEF Nexus Index. William Becker contributed to the final manuscript. Jessica Badenhorst assisted with the selection of indicators and in the literature review of the WEF nexus in South Africa. Pere Rovira and Victor Pascual developed the data visualisations and described the philosophy and importance of visualisation in this study.

\section{$10 \quad$ Funding}


This work is based on the research supported by the Water Research Commission (Project Number K5/2959) and the National Research Foundation (Grant Number: 114692), both of South Africa, and the Ministry of Foreign Affairs of the Netherlands through the WEF-Tools project of the Partnership Programme for Water and Development (DUPC2) under Activity Number no. 28325 / DME0121369. 
Addendum A: WEF Nexus Index - Indicator selection table

\begin{tabular}{|c|c|c|c|c|c|c|c|c|}
\hline No. & Sector & Indicator & Definition $^{1}$ & Source & Units & Data availability & SDG Indicator? (Y/N) & $\begin{array}{c}\text { Reason/motivation for } \\
\text { inclusion/exclusion }\end{array}$ \\
\hline 1 & $\begin{array}{l}\text { Water } \\
\text { (SDG 6) }\end{array}$ & $\begin{array}{l}\text { The percentage of } \\
\text { people using at least } \\
\text { basic drinking water } \\
\text { services }\end{array}$ & $\begin{array}{l}\text { This indicator encompasses both people using basic } \\
\text { water services as well as those using safely managed } \\
\text { water services. Basic drinking water services are } \\
\text { defined as drinking water from an improved source, } \\
\text { provided collection time is not more than } 30 \text { minutes } \\
\text { for a round trip. Improved water sources include piped } \\
\text { water, boreholes or tube wells, protected dug wells, } \\
\text { protected springs, and packaged or delivered water } \\
\text { (FAO.org 2018, Accessed 2019-03-01). }\end{array}$ & $\begin{array}{l}\text { http://www.fao.org/economic/ess/ess- } \\
\text { fs/ess-fadata/en/\#.WDmBh9V96Uk } \\
\text { Source: World Bank: } \\
\text { http://data.worldbank.org/indicator/SH } \\
\text {.H2O.BASW.ZS. } \\
\text { Original source: WHO/UNICEF Joint } \\
\text { Monitoring Programme (JMP) for Water } \\
\text { Supply, Sanitation and Hygiene } \\
\text { (washdata.org). Accessed 2019-03-01 }\end{array}$ & $\%$ & $\begin{array}{l}2015 \\
\text { Very good data } \\
\text { coverage. The } \\
\text { indicator is } \\
\text { utilised in SDG } \\
\text { Index for SDG } 6\end{array}$ & $\begin{array}{l}\text { No, but 6.1.1 } \\
\text { (Proportion of } \\
\text { population using } \\
\text { safely managed } \\
\text { drinking water } \\
\text { services) } \\
\text { and 6.3.2 are SDG } \\
\text { indices. It is FAO } \\
\text { indicator I_4.1 }\end{array}$ & $\begin{array}{l}\text { Yes; very good data, and } \\
\text { the indicator is relevant } \\
\text { to SDG } 6 \text {. Alternative to } \\
\text { official indicator } 6.1 .1 \\
\text { since it has better data } \\
\text { coverage for many } \\
\text { nations }\end{array}$ \\
\hline 2 & $\begin{array}{l}\text { Water } \\
\text { (SDG 6) }\end{array}$ & $\begin{array}{l}\text { People using safely } \\
\text { managed drinking } \\
\text { water services }\end{array}$ & $\begin{array}{l}\text { The percentage of the population using drinking water } \\
\text { from an improved water source which is located on } \\
\text { premises, available when needed and free from faecal } \\
\text { and priority chemical contamination (FAO.org 2018, } \\
\text { Accessed 2019-03-01) }\end{array}$ & $\begin{array}{l}\text { http://www.fao.org/economic/ess/ess- } \\
\text { fs/ess-fadata/en/\#.WDmBh9V96Uk } \\
\text { Source: World Bank: } \\
\text { http://data.worldbank.org/indicator/SH } \\
\text {.H2O.SMDW.ZS } \\
\text { Original source: World Health } \\
\text { Organization and United Nations } \\
\text { Children's Fund, Joint Measurement } \\
\text { Programme (JMP) } \\
\text { (http://www.wssinfo.org/). Accessed } \\
\text { 2019-03-01 }\end{array}$ & $\%$ & $\begin{array}{l}2015 \\
\text { Data coverage } \\
\text { relatively sparse }\end{array}$ & $\begin{array}{l}\text { Yes, 6.1.1. It is FAO } \\
\text { indicator I_4.2 }\end{array}$ & $\begin{array}{l}\text { No; rather use "The } \\
\text { percentage of people } \\
\text { using at least basic } \\
\text { drinking water services" } \\
\text { as equivalent indicator } \\
\text { since it has better data } \\
\text { coverage }\end{array}$ \\
\hline 3 & $\begin{array}{l}\text { Water } \\
\text { (SDG 6) }\end{array}$ & $\begin{array}{l}\text { Percentage of } \\
\text { people using at least } \\
\text { basic sanitation } \\
\text { services. }\end{array}$ & $\begin{array}{l}\text { The percentage of people using at least basic sanitation } \\
\text { services, that is, improved sanitation facilities that are } \\
\text { not shared with other households. This indicator } \\
\text { encompasses both people using basic sanitation } \\
\text { services as well as those using safely managed } \\
\text { sanitation services. Improved sanitation facilities } \\
\text { include flush/pour flush to piped sewer systems, septic } \\
\text { tanks or pit latrines; ventilated improved pit latrines, } \\
\text { compositing toilets or pit latrines with slabs (FAO.org } \\
2018 \text {, Accessed 2019-03-01). }\end{array}$ & $\begin{array}{l}\text { http://www.fao.org/economic/ess/ess- } \\
\text { fs/ess-fadata/en/\#.WDmBh9V96Uk } \\
\text { Source: World Development Indicators: } \\
\text { World Bank: } \\
\text { http://data.worldbank.org/indicator/SH } \\
\text { STA.BASS.ZS. } \\
\text { Original source: World Health } \\
\text { Organization and United Nations } \\
\text { Children's Fund, Joint Measurement } \\
\text { Programme (JMP) } \\
\text { (http://www.wssinfo.org/). Accessed } \\
\text { 2019-03-01 }\end{array}$ & $\%$ & $\begin{array}{l}2015 \\
\text { Very good data } \\
\text { coverage. The } \\
\text { indicator is } \\
\text { utilised in SDG } \\
\text { Index for SDG } 6\end{array}$ & $\begin{array}{l}\text { No, but } 6.2 .1 \text { and } 6.3 .1 \\
\text { are SDG indices. It is } \\
\text { FAO indicator I_4.3 }\end{array}$ & $\begin{array}{l}\text { No; very good data, and } \\
\text { the indicator is relevant } \\
\text { to SDG 6, but } \\
\text { "Percentage of people } \\
\text { using safely managed } \\
\text { sanitation services" is an } \\
\text { official SDG indicator, } \\
6.2 .1 \text {, and FAO lists the } \\
\text { exact same data for the } \\
\text { two. }\end{array}$ \\
\hline 4 & $\begin{array}{l}\text { Water } \\
\text { (SDG 6) }\end{array}$ & $\begin{array}{l}\text { Percentage of } \\
\text { people using safely } \\
\text { managed sanitation } \\
\text { services. }\end{array}$ & $\begin{array}{l}\text { The percentage of the population using improved } \\
\text { sanitation facilities which are not shared with other } \\
\text { households and where excreta are safely disposed in } \\
\text { situ or transported and treated off-site (FAO.org 2018, } \\
\text { Accessed 2019-03-01). }\end{array}$ & $\begin{array}{l}\text { http://www.fao.org/economic/ess/ess- } \\
\text { fs/ess-fadata/en/\#.WDmBh9V96Uk } \\
\text { Source: World Development Indicators: } \\
\text { World Bank: } \\
\text { http://data.worldbank.org/indicator/ } \\
\text { SH.STA.SMSS.ZS. } \\
\text { Original source: World Health } \\
\text { Organization and United Nations } \\
\text { Children's Fund, Joint Measurement } \\
\text { Programme (JMP) }\end{array}$ & $\%$ & $\begin{array}{l}2015 \\
\text { Very good data } \\
\text { coverage. Data is } \\
\text { identical to } \\
\text { "Percentage of } \\
\text { people using at } \\
\text { least basic } \\
\text { sanitation } \\
\text { services." }\end{array}$ & $\begin{array}{l}\text { Yes, } 6.2 .1 \text { and it is FAO } \\
\text { indicator I_4.4 }\end{array}$ & $\begin{array}{l}\text { Yes; very good data } \\
\text { coverage and indicator is } \\
\text { an official SDG indicator }\end{array}$ \\
\hline
\end{tabular}

${ }^{1}$ Definitions from websites listed in "Source" column of table 


\begin{tabular}{|c|c|c|c|c|c|c|c|c|}
\hline & & & & $\begin{array}{l}\text { (http://www.wssinfo.org/). Accessed } \\
\text { 2019-03-01 }\end{array}$ & & & & \\
\hline 5 & $\begin{array}{l}\text { Water } \\
\text { (SDG 6) }\end{array}$ & $\begin{array}{l}\text { Infrastructure } \\
\text { leakage index }\end{array}$ & $\begin{array}{l}\text { Performance indicator for real losses, which measures } \\
\text { the ratio of current annual real losses to system- } \\
\text { specific unavoidable annual real losses. It is the ideal } \\
\text { indicator for making international comparison } \\
\text { (Winarni, 2009). The Infrastructure Leakage Index (ILI) } \\
\text { is a performance indicator that is used to indicate the } \\
\text { level of Real Losses (i.e. Physical leakage) in a water } \\
\text { distribution system (Mckenzie et al. 2012). The ILI is a } \\
\text { non-dimensional indicator and ranges from } 1 \text { to over } \\
100 \text { and could be considered as an alternative to the } \\
\text { Non-Revenue Water value. An ILI value of } 1 \text { equates to } \\
\text { the "world's best practice" and indicates that the level } \\
\text { of physical leakage in a system is as low as it can be, } \\
\text { while a value of ten would indicate that the physical } \\
\text { leakage is ten times larger than the lowest value. }\end{array}$ & & - & $\begin{array}{l}\text { On an } \\
\text { international level } \\
\text { uniformity in } \\
\text { measuring, } \\
\text { interpreting or } \\
\text { reporting of the } \\
\text { ILI does not exist. }\end{array}$ & No & $\begin{array}{l}\text { No, data not comparable } \\
\text { on an international level }\end{array}$ \\
\hline 6 & $\begin{array}{l}\text { Water } \\
\text { (SDG 6) }\end{array}$ & Non-Revenue Water & $\begin{array}{l}\text { A measure of the municipal efficiency of water } \\
\text { management, Non-Revenue Water is the sum of } \\
\text { unbilled authorised water, commercial losses and real } \\
\text { or physical losses. }\end{array}$ & & $\begin{array}{l}\text { Million } \\
\mathrm{m}^{3} / \text { annum }\end{array}$ & $\begin{array}{l}\text { On an } \\
\text { international level } \\
\text { uniformity in } \\
\text { measuring, } \\
\text { interpreting or } \\
\text { reporting of the } \\
\text { non-revenue } \\
\text { water does not } \\
\text { exist. }\end{array}$ & No & $\begin{array}{l}\text { No, data not comparable } \\
\text { on an international level }\end{array}$ \\
\hline 7 & $\begin{array}{l}\text { Water } \\
\text { (SDG 6) }\end{array}$ & $\begin{array}{l}\text { Annual freshwater } \\
\text { withdrawals, total } \\
\text { (\% of internal } \\
\text { resources) }\end{array}$ & $\begin{array}{l}\text { Annual freshwater withdrawals refer to total water } \\
\text { withdrawals, not counting evaporation losses from } \\
\text { storage basins. Withdrawals also include water from } \\
\text { desalination plants in countries where they are a } \\
\text { significant source. Withdrawals can exceed } 100 \\
\text { percent of total renewable resources where extraction } \\
\text { from nonrenewable aquifers or desalination plants is } \\
\text { considerable or where there is significant water reuse. } \\
\text { Withdrawals for agriculture and industry are total } \\
\text { withdrawals for irrigation and livestock production and } \\
\text { for direct industrial use (including withdrawals for } \\
\text { cooling thermoelectric plants). Withdrawals for } \\
\text { domestic uses include drinking water, municipal use or } \\
\text { supply, and use for public services, commercial } \\
\text { establishments, and homes (World Bank 2019-03-01) }\end{array}$ & $\begin{array}{l}\text { https://data.worldbank.org/indicator/E } \\
\text { R.H2O.FWTL.ZS?view=chart } \\
\text { Source: Food and Agriculture } \\
\text { Organization, AQUASTAT data }\end{array}$ & $\%$ & $\begin{array}{l}2002-2014 \\
\text { Limited data } \\
\text { coverage. } \\
\text { Indicator utilised } \\
\text { in SDG Index for } \\
\text { SDG } 6 \text {. Need to } \\
\text { use the most } \\
\text { recent values } \\
\text { from the database }\end{array}$ & $\begin{array}{l}\text { Yes, 6.4.2 } \\
\text { C060402 }\end{array}$ & $\begin{array}{l}\text { Yes, this is an official } \\
\text { SDG indicator, and } \\
\text { utilising the most recent } \\
\text { values from 2002-2014 a } \\
\text { good coverage of data is } \\
\text { obtained. This dataset } \\
\text { will however require } \\
\text { Winsorization in order to } \\
\text { remove the distorting } \\
\text { effect of outliers, and to } \\
\text { avoid too large a space } \\
\text { in the dataset. Data } \\
\text { could be truncated at } \\
200 \%, \text { which represents } \\
\text { double the available } \\
\text { fresh water resources of } \\
\text { the country. }\end{array}$ \\
\hline 8 & $\begin{array}{l}\text { Water } \\
\text { (SDG 6) }\end{array}$ & $\begin{array}{l}\text { Water withdrawal in } \\
\text { the agriculture } \\
\text { sector }\end{array}$ & $\begin{array}{l}\text { Annual quantity of self-supplied water withdrawn for } \\
\text { irrigation, livestock and aquaculture purposes. It can } \\
\text { include water from primary renewable and secondary } \\
\text { freshwater resources, as well as water from over- } \\
\text { abstraction of renewable groundwater or withdrawal } \\
\text { from fossil groundwater, direct use of agricultural } \\
\text { drainage water, direct use of (treated) wastewater, and } \\
\text { desalinated water. Water for the dairy and meat } \\
\text { industries and industrial processing of harvested }\end{array}$ & $\begin{array}{l}\text { http://www.fao.org/nr/water/aquastat } \\
\text { data/query/index.html?lang=en } \\
\text { Source: Food and Agriculture } \\
\text { Organization, AQUASTAT data }\end{array}$ & $\begin{array}{l}10^{9} \mathrm{~m}^{3} \\
/ \text { year }\end{array}$ & $\begin{array}{l}\text { Data available } \\
\text { from } 1965-2017 \\
\text { with many missing } \\
\text { data per year. } \\
\text { Most data are } \\
\text { available for } 2000 \\
\text { for } 68 \text { countries. }\end{array}$ & No & $\begin{array}{l}\text { No, although data is } \\
\text { available for many } \\
\text { countries, the data is } \\
\text { missing for many } \\
\text { monitoring years } \\
\text { resulting in an } \\
\text { incomplete dataset. }\end{array}$ \\
\hline
\end{tabular}




\begin{tabular}{|c|c|c|c|c|c|c|c|c|}
\hline & & & $\begin{array}{l}\text { agricultural products is included under industrial water } \\
\text { withdrawal (FAO 2019-05-25) }\end{array}$ & & & & & \\
\hline 9 & $\begin{array}{l}\text { Water } \\
\text { (SDG 6) }\end{array}$ & $\begin{array}{l}\text { Water withdrawal in } \\
\text { the industry sector }\end{array}$ & $\begin{array}{l}\text { Annual quantity of self-supplied water withdrawn for } \\
\text { industrial uses. It can include water from primary } \\
\text { renewable and secondary freshwater resources, as well } \\
\text { as water from over-abstraction of renewable } \\
\text { groundwater or withdrawal from fossil groundwater, } \\
\text { direct use of agricultural drainage water, direct use of } \\
\text { (treated) wastewater, and desalinated water. This } \\
\text { sector refers to self-supplied industries not connected } \\
\text { to the public distribution network. The ratio between } \\
\text { net consumption and withdrawal is estimated at less } \\
\text { than } 5 \% \text {. It includes water for the cooling of } \\
\text { thermoelectric and nuclear power plants, but it does } \\
\text { not include hydropower. Water withdrawn by } \\
\text { industries that are connected to the public supply } \\
\text { network is generally included in municipal water } \\
\text { withdrawal. (FAO 2019-05-25) }\end{array}$ & $\begin{array}{l}\text { http://www.fao.org/nr/water/aquastat } \\
\text { data/query/index.html?lang=en } \\
\text { Source: Food and Agriculture } \\
\text { Organization, AQUASTAT data }\end{array}$ & $\begin{array}{l}10^{9} \mathrm{~m}^{3} \\
\text { /year }\end{array}$ & $\begin{array}{l}\text { Data available } \\
\text { from 1965-2017 } \\
\text { with many missing } \\
\text { data per year. } \\
\text { Most data are } \\
\text { available for } 2000 \\
\text { for } 93 \text { countries. }\end{array}$ & No & $\begin{array}{l}\text { No, although data is } \\
\text { available for many } \\
\text { countries, the data is } \\
\text { missing for many } \\
\text { monitoring years } \\
\text { resulting in an } \\
\text { incomplete dataset. }\end{array}$ \\
\hline 10 & $\begin{array}{l}\text { Water } \\
\text { (SDG 6) }\end{array}$ & $\begin{array}{l}\text { Water withdrawal in } \\
\text { the industry sector }\end{array}$ & $\begin{array}{l}\text { Annual quantity of water withdrawn primarily for the } \\
\text { direct use by the population. It can include water from } \\
\text { primary renewable and secondary freshwater } \\
\text { resources, as well as water from over-abstraction of } \\
\text { renewable groundwater or withdrawal from fossil } \\
\text { groundwater, direct use of agricultural drainage water, } \\
\text { direct use of (treated) wastewater, and desalinated } \\
\text { water. It is usually computed as the total water } \\
\text { withdrawn by the public distribution network. It can } \\
\text { include that part of the industries and urban } \\
\text { agriculture, which is connected to the municipal } \\
\text { network. The ratio between the net consumption and } \\
\text { the water withdrawn can vary from } 5 \text { to } 15 \% \text { in urban } \\
\text { areas and from } 10 \text { to } 50 \% \text { in rural areas. (FAO 2019-05- } \\
\text { 25) }\end{array}$ & $\begin{array}{l}\text { http://www.fao.org/nr/water/aquastat } \\
\text { data/query/index.html?lang=en } \\
\text { Source: Food and Agriculture } \\
\text { Organization, AQUASTAT data }\end{array}$ & $\begin{array}{l}10^{9} \mathrm{~m}^{3} \\
\text { /year }\end{array}$ & $\begin{array}{l}\text { Data available } \\
\text { from } 1965-2017 \\
\text { with many missing } \\
\text { data per year. } \\
\text { Most data are } \\
\text { available for } 2000 \\
\text { for } 91 \text { countries. }\end{array}$ & No & $\begin{array}{l}\text { No, although data is } \\
\text { available for many } \\
\text { countries, the data is } \\
\text { missing for many } \\
\text { monitoring years } \\
\text { resulting in an } \\
\text { incomplete dataset. }\end{array}$ \\
\hline 11 & $\begin{array}{l}\text { Water } \\
\text { (SDG 6) }\end{array}$ & $\begin{array}{l}\text { Fresh groundwater } \\
\text { withdrawal (primary } \\
\text { and secondary) - } \\
\text { Total }\end{array}$ & $\begin{array}{l}\text { Annual gross amount of water extracted from aquifers. } \\
\text { It can include withdrawal of renewable primary and } \\
\text { secondary groundwater, as well as water from over- } \\
\text { abstraction of renewable groundwater or withdrawal } \\
\text { from fossil groundwater.(FAO 2019-05-25) }\end{array}$ & $\begin{array}{l}\text { http://www.fao.org/nr/water/aquastat } \\
\text { data/query/index.html?lang=en } \\
\text { Source: Food and Agriculture } \\
\text { Organization, AQUASTAT data }\end{array}$ & $\begin{array}{l}10^{9} \mathrm{~m}^{3} \\
/ \text { year }\end{array}$ & $\begin{array}{l}\text { Data available } \\
\text { from } 1965-2017 \\
\text { with many missing } \\
\text { data per year. } \\
\text { Most data are } \\
\text { available for } 2000 \\
\text { for } 91 \text { countries. }\end{array}$ & No & $\begin{array}{l}\text { No, although data is } \\
\text { available for many } \\
\text { countries, the data is } \\
\text { missing for many } \\
\text { monitoring years } \\
\text { resulting in an } \\
\text { incomplete dataset. }\end{array}$ \\
\hline 12 & $\begin{array}{l}\text { Water } \\
\text { (SDG 6) }\end{array}$ & $\begin{array}{l}\text { Desalinated water } \\
\text { produced }\end{array}$ & $\begin{array}{l}\text { Water produced annually by desalination of brackish or } \\
\text { salt water. It is estimated annually on the basis of the } \\
\text { total capacity of water desalination installations..(FAO } \\
\text { 2019-05-25) }\end{array}$ & $\begin{array}{l}\text { http://www.fao.org/nr/water/aquastat } \\
\text { data/query/index.html?lang=en } \\
\text { Source: Food and Agriculture } \\
\text { Organization, AQUASTAT data }\end{array}$ & $\begin{array}{l}10^{9} \mathrm{~m}^{3} \\
/ \text { year }\end{array}$ & $\begin{array}{l}\text { Data available } \\
\text { from 1980-2015 } \\
\text { with many missing } \\
\text { data per year. } \\
\text { Most data are } \\
\text { available for } 2000 \\
\text { for } 49 \text { countries. }\end{array}$ & No & $\begin{array}{l}\text { No, although data is } \\
\text { available for many } \\
\text { countries, the data is } \\
\text { missing for many } \\
\text { monitoring years } \\
\text { resulting in an } \\
\text { incomplete dataset. }\end{array}$ \\
\hline 13 & $\begin{array}{l}\text { Water } \\
\text { (SDG 6) }\end{array}$ & $\begin{array}{l}\text { Treated municipal } \\
\text { water }\end{array}$ & $\begin{array}{l}\text { Treated wastewater (primary, secondary and tertiary) } \\
\text { annually produced by municipal wastewater treatment } \\
\text { facilities in the country. } \\
\text { Primary treatment:municipal wastewater effectively } \\
\text { treated by a physical and/or chemical process involving }\end{array}$ & $\begin{array}{l}\text { http://www.fao.org/nr/water/aquastat } \\
\text { data/query/index.html?lang=en } \\
\text { Source: Food and Agriculture } \\
\text { Organization, AQUASTAT data }\end{array}$ & $\begin{array}{l}10^{9} \mathrm{~m}^{3} \\
/ \text { year }\end{array}$ & $\begin{array}{l}\text { Data available } \\
\text { from 1967-2017 } \\
\text { with many missing } \\
\text { data per year. } \\
\text { Most data are }\end{array}$ & No & $\begin{array}{l}\text { No, although data is } \\
\text { available for many } \\
\text { countries, the data is } \\
\text { missing for many } \\
\text { monitoring years }\end{array}$ \\
\hline
\end{tabular}




\begin{tabular}{|c|c|c|c|c|c|c|c|c|}
\hline & & & $\begin{array}{l}\text { settlement of suspended solids, or other process in } \\
\text { which the BOD5 of the incoming wastewater is } \\
\text { reduced by at least } 20 \% \text { and the total suspended solids } \\
\text { of the incoming wastewater are reduced by at least } \\
50 \% \text { before discharge. Treatment processes can } \\
\text { include: sedimentation tank, septic tank, skimming, } \\
\text { chemical enhanced primary treatment. } \\
\text { Secondary treatment:municipal wastewater effectively } \\
\text { treated by a process generally involving biological } \\
\text { treatment with a secondary settlement or other } \\
\text { process, resulting in a BOD removal of at least 70\% and } \\
\text { a COD removal of at least } 75 \% \text { before discharge. } \\
\text { Treatment processes can include: aerated lagoon, } \\
\text { activated sludge, up-flow anaerobic sludge blanket, } \\
\text { trickling filters, rotating biological contactors, oxidation } \\
\text { ditch, settling basin digester. For the purpose of this } \\
\text { database natural biological treatment processes are } \\
\text { also considered under secondary treatment as the } \\
\text { constituents of the effluents from this type of } \\
\text { treatment is similar to the conventional secondary } \\
\text { treatment. Natural biological treatment refers to the } \\
\text { process other than conventional wastewater treatment } \\
\text { (primary, secondary, tertiary). This treatment makes } \\
\text { use of natural bio-chemical processes to treat } \\
\text { wastewater and can include: waste stabilization pond, } \\
\text { constructed wetlands, overland treatment, nutrient } \\
\text { film techniques, soil aquifer treatment, high-rate algal } \\
\text { pond, floating aquatic macrophyte systems. } \\
\text { Tertiary treatment:municipal wastewater effectively } \\
\text { treated by a process in addition to secondary } \\
\text { treatment of nitrogen and/or phosphorous and/or any } \\
\text { other specific pollutant affecting the quality or a } \\
\text { specific use of water: microbiological pollution, colour, } \\
\text { etc. This treatment is meant to remove at least } 95 \% \text { for } \\
\text { BOD and } 85 \% \text { for cOD and/or a nitrogen removal of at } \\
\text { least } 70 \% \text { and/or a phosphorus removal of at least } 80 \% \\
\text { and/or a microbiological removal. Treatment process } \\
\text { can include: membrane filtration (micro-; nano-; ultra- } \\
\text { and reverse osmosis), infiltration / percolation, } \\
\text { activated carbon, disinfection (chlorination, ozone, } \\
\text { UV)...(FAO 2019-05-25) }\end{array}$ & & & $\begin{array}{l}\text { available for } 2012 \\
\text { for } 25 \text { countries. }\end{array}$ & & $\begin{array}{l}\text { resulting in an } \\
\text { incomplete dataset. }\end{array}$ \\
\hline 14 & $\begin{array}{l}\text { Water } \\
\text { (SDG 6) }\end{array}$ & $\begin{array}{l}\text { Direct use of } \\
\text { treatment municipal } \\
\text { water }\end{array}$ & $\begin{array}{l}\text { Treated municipal wastewater (primary, secondary, } \\
\text { tertiary effluents) directly used, i.e. with no or little } \\
\text { prior dilution with freshwater during most of the year. }\end{array}$ & $\begin{array}{l}\text { http://www.fao.org/nr/water/aquastat } \\
\text { /data/query/index.html?lang=en } \\
\text { Source: Food and Agriculture } \\
\text { Organization, AQUASTAT data }\end{array}$ & $\begin{array}{l}10^{9} \mathrm{~m}^{3} \\
/ \text { year }\end{array}$ & $\begin{array}{l}\text { Data available } \\
\text { from } 1967-2013 \\
\text { with many missing } \\
\text { data per year. } \\
\text { Most data are } \\
\text { available for } 2000 \\
\text { for } 15 \text { countries. }\end{array}$ & No & $\begin{array}{l}\text { No, although data is } \\
\text { available for many } \\
\text { countries, the data is } \\
\text { missing for many } \\
\text { monitoring years } \\
\text { resulting in an } \\
\text { incomplete dataset. }\end{array}$ \\
\hline 15 & $\begin{array}{l}\text { Water } \\
\text { (SDG 6) }\end{array}$ & $\begin{array}{l}\text { Environmental flow } \\
\text { requirements }\end{array}$ & $\begin{array}{l}\text { The quantity and timing of freshwater flows and levels } \\
\text { necessary to sustain aquatic ecosystems which, in turn, } \\
\text { support human cultures, economies, sustainable }\end{array}$ & $\begin{array}{l}\text { http://www.fao.org/nr/water/aquastat } \\
\text { /data/query/index.html?lang=en } \\
\text { Source: Food and Agriculture } \\
\text { Organization, AQUASTAT data }\end{array}$ & $\begin{array}{l}10^{9} \mathrm{~m}^{3} \\
/ \text { year }\end{array}$ & $\begin{array}{l}\text { Data available } \\
\text { from 1962-2017 } \\
\text { with many missing } \\
\text { data per year. } \\
\end{array}$ & No & $\begin{array}{l}\text { Yes, it is important that } \\
\text { water's contribution } \\
\text { required for sustaining } \\
\text { the environment is taken }\end{array}$ \\
\hline
\end{tabular}




\begin{tabular}{|c|c|c|c|c|c|c|c|c|}
\hline & & & $\begin{array}{l}\text { livelihoods, and wellbeing" (Adapted from Arthington, } \\
\text { A.H., et al. 2018). }\end{array}$ & & & $\begin{array}{l}\text { Most data are } \\
\text { available for } 2017 \\
\text { for } 154 \text { countries. }\end{array}$ & & $\begin{array}{l}\text { into account. Good } \\
\text { correlation with } \\
\text { renewable internal fresh } \\
\text { water resources }(0.58) \\
\end{array}$ \\
\hline 16 & $\begin{array}{l}\text { Water } \\
\text { (SDG 6) }\end{array}$ & $\begin{array}{l}\text { Percentage of area } \\
\text { equipped for } \\
\text { irrigation by surface } \\
\text { water }\end{array}$ & $\begin{array}{l}\text { Area equipped for irrigation irrigated by surface water } \\
\text { as percentage of the total area equipped for irrigation }\end{array}$ & $\begin{array}{l}\text { http://www.fao.org/nr/water/aquastat } \\
\text { /data/query/index.html?lang=en } \\
\text { Source: Food and Agriculture } \\
\text { Organization, AQUASTAT data }\end{array}$ & $\%$ & $\begin{array}{l}\text { Data available } \\
\text { from } 1962-2014 \\
\text { with many missing } \\
\text { data per year. } \\
\text { Most data are } \\
\text { available for } 1994 \\
\text { for } 19 \text { countries. }\end{array}$ & No & $\begin{array}{l}\text { No, although data is } \\
\text { available for many } \\
\text { countries, the data is } \\
\text { missing for many } \\
\text { monitoring years } \\
\text { resulting in an } \\
\text { incomplete dataset. }\end{array}$ \\
\hline 17 & $\begin{array}{l}\text { Water } \\
\text { (SDG 6) }\end{array}$ & $\begin{array}{l}\text { Percentage of area } \\
\text { equipped for } \\
\text { irrigation by ground } \\
\text { water }\end{array}$ & $\begin{array}{l}\text { Equipped for irrigation area irrigated by groundwater } \\
\text { as percentage of the total equipped for irrigation area. }\end{array}$ & $\begin{array}{l}\text { http://www.fao.org/nr/water/aquastat } \\
\text { /data/query/index.html?lang=en } \\
\text { Source: Food and Agriculture } \\
\text { Organization, AQUASTAT data }\end{array}$ & $\%$ & $\begin{array}{l}\text { Data available } \\
\text { from } 1962-2014 \\
\text { with many missing } \\
\text { data per year. } \\
\text { Most data are } \\
\text { available for } 1994 \\
\text { for } 17 \text { countries. }\end{array}$ & No & $\begin{array}{l}\text { No, although data is } \\
\text { available for many } \\
\text { countries, the data is } \\
\text { missing for many } \\
\text { monitoring years } \\
\text { resulting in an } \\
\text { incomplete dataset. }\end{array}$ \\
\hline 18 & $\begin{array}{l}\text { Water } \\
\text { (SDG 6) }\end{array}$ & $\begin{array}{l}\text { Percentage of total } \\
\text { grain production } \\
\text { irrigated }\end{array}$ & $\begin{array}{l}\text { Percent of the total grain production of the country } \\
\text { (rainfed and irrigated) that is irrigated in a given year, } \\
\text { expressed in percentage. }\end{array}$ & $\begin{array}{l}\text { http://www.fao.org/nr/water/aquastat } \\
\text { data/query/index.html?lang=en } \\
\text { Source: Food and Agriculture } \\
\text { Organization, AQUASTAT data }\end{array}$ & $\%$ & $\begin{array}{l}\text { Data available } \\
\text { from } 1984-1995 \\
\text { with many missing } \\
\text { data per year. } \\
\text { Most data are } \\
\text { available for } 1994 \\
\text { for } 13 \text { countries. }\end{array}$ & No & $\begin{array}{l}\text { No, although data is } \\
\text { available for many } \\
\text { countries, the data is } \\
\text { missing for many } \\
\text { monitoring years } \\
\text { resulting in an } \\
\text { incomplete dataset. }\end{array}$ \\
\hline 19 & $\begin{array}{l}\text { Water } \\
\text { (SDG 6) }\end{array}$ & $\begin{array}{l}\text { Renewable internal } \\
\text { freshwater } \\
\text { resources per capita } \\
\text { (cubic meters) }\end{array}$ & $\begin{array}{l}\text { Renewable internal freshwater resources flows refer to } \\
\text { internal renewable resources (internal river flows and } \\
\text { groundwater from rainfall) in the country. Renewable } \\
\text { internal freshwater resources per capita are calculated } \\
\text { using the World Bank's population estimates (World } \\
\text { Bank 2019-03-01). }\end{array}$ & $\begin{array}{l}\text { https://data.worldbank.org/indicator/E } \\
\text { R.H2O.INTR.PC?view=chart } \\
\text { Source: Food and Agriculture } \\
\text { Organization, AQUASTAT data }\end{array}$ & $\mathrm{m}^{3} /$ capita & $\begin{array}{l}2014 \\
\text { Very good data } \\
\text { coverage }\end{array}$ & No & $\begin{array}{l}\text { Yes, very good data } \\
\text { coverage, and the "per } \\
\text { capita" unit provides a } \\
\text { helpful measure } \\
\text { between countries with } \\
\text { an indicator of relative } \\
\text { scarcity. Good } \\
\text { correlation with annual } \\
\text { fresh water reseources, } \\
\text { but not too high to } \\
\text { warrant exclusion }(0.78)\end{array}$ \\
\hline 20 & $\begin{array}{l}\text { Water } \\
\text { (SDG 6) }\end{array}$ & $\begin{array}{l}\text { Renewable internal } \\
\text { freshwater } \\
\text { resources, total } \\
\text { (billion cubic } \\
\text { meters) }\end{array}$ & $\begin{array}{l}\text { Renewable internal freshwater resources flows refer to } \\
\text { internal renewable resources (internal river flows and } \\
\text { groundwater from rainfall) in the country (World Bank } \\
\text { 2019-03-04). }\end{array}$ & $\begin{array}{l}\text { https://data.worldbank.org/indicator/E } \\
\text { R.H2O.INTR.K3?view=chart } \\
\text { Source: Food and Agriculture } \\
\text { Organization, AQUASTAT data }\end{array}$ & Billion $\mathrm{m}^{3}$ & $\begin{array}{l}2014 \\
\text { Very good data } \\
\text { coverage }\end{array}$ & No & $\begin{array}{l}\text { No, this is the same data } \\
\text { as the "Renewable } \\
\text { internal freshwater } \\
\text { resources per capita } \\
\text { (cubic meters)" but as a } \\
\text { quantum instead of per } \\
\text { capita }\end{array}$ \\
\hline 21 & $\begin{array}{l}\text { Water } \\
\text { (SDG 6) }\end{array}$ & $\begin{array}{l}\text { Hydropower } \\
\text { electricity capacity } \\
\text { (MW) }\end{array}$ & Hydropower and renewable hydropower & $\begin{array}{l}\text { https://www.irena.org/Statistics/View- } \\
\text { Data-by-Topic/Capacity-and- } \\
\text { Generation/Technologies } \\
\text { Source: Source: IRENA (2019), } \\
\text { Renewable capacity statistics 2019; and } \\
\text { IRENA (2018), Renewable Energy } \\
\text { Statistics 2018, The International } \\
\text { Renewable Energy Agency, Abu Dhabi. }\end{array}$ & MW & $\begin{array}{l}\text { Data available } \\
\text { from 2000-2018 } \\
\text { with minimal } \\
\text { missing data per } \\
\text { year. Most data } \\
\text { are available for } \\
2018 \text { for } 159 \\
\text { countries. }\end{array}$ & No & $\begin{array}{l}\text { No, this data is included } \\
\text { in the renewable energy } \\
\text { consumption and output } \\
\text { indicators }\end{array}$ \\
\hline
\end{tabular}




\begin{tabular}{|c|c|c|c|c|c|c|c|c|}
\hline 22 & $\begin{array}{l}\text { Water } \\
\text { (SDG 6) }\end{array}$ & $\begin{array}{l}\text { Hydropower } \\
\text { electricity } \\
\text { generation (GWh) }\end{array}$ & Hydropower and renewable hydropower & $\begin{array}{l}\text { https://www.irena.org/Statistics/View- } \\
\text { Data-by-Topic/Capacity-and- } \\
\text { Generation/Technologies } \\
\text { Source: Source: IRENA (2019), } \\
\text { Renewable capacity statistics 2019; and } \\
\text { IRENA (2018), Renewable Energy } \\
\text { Statistics 2018, The International } \\
\text { Renewable Energy Agency, Abu Dhabi. }\end{array}$ & GWh & $\begin{array}{l}\text { Data available } \\
\text { from 2000-2016 } \\
\text { with minimal } \\
\text { missing data per } \\
\text { year. Most data } \\
\text { are available for } \\
2016 \text { for } 159 \\
\text { countries. }\end{array}$ & No & $\begin{array}{l}\text { No, this data is included } \\
\text { in the renewable energy } \\
\text { consumption and output } \\
\text { indicators }\end{array}$ \\
\hline 23 & $\begin{array}{l}\text { Water } \\
\text { (SDG 6) }\end{array}$ & $\begin{array}{l}\text { Average } \\
\text { precipitation in } \\
\text { depth ( } \mathrm{mm} \text { per } \\
\text { year) }\end{array}$ & $\begin{array}{l}\text { Average precipitation is the long-term average in depth } \\
\text { (over space and time) of annual precipitation in the } \\
\text { country. Precipitation is defined as any kind of water } \\
\text { that falls from clouds as a liquid or a solid (World Bank } \\
\text { 2019-03-04). }\end{array}$ & $\begin{array}{l}\text { https://data.worldbank.org/indicator/A } \\
\text { G.LND.PRCP.MM } \\
\text { Source: Food and Agriculture } \\
\text { Organization, electronic files and } \\
\text { website }\end{array}$ & $\begin{array}{l}\mathrm{mm} / \\
\text { year }\end{array}$ & $\begin{array}{l}2014 \\
\text { Very good data } \\
\text { coverage }\end{array}$ & No & $\begin{array}{l}\text { Yes; this data is widely } \\
\text { available and provides a } \\
\text { good indication of } \\
\text { available fresh water. } \\
\text { This indicator directly } \\
\text { influences food } \\
\text { production and energy } \\
\text { generation. Good } \\
\text { correlation with annual } \\
\text { freshwater withdrawals }\end{array}$ \\
\hline 24 & $\begin{array}{l}\text { Water } \\
\text { (SDG 6) }\end{array}$ & $\begin{array}{l}\text { Proportion of } \\
\text { wastewater safely } \\
\text { treated }\end{array}$ & $\begin{array}{l}\text { Percentage of wastewater generated by households } \\
\text { (sewage and faecal sludge) and economic activities } \\
\text { (based on ISIC categories) that is safely treated (UN } \\
\text { Water, 2016). }\end{array}$ & $\begin{array}{l}\text { http://www.fao.org/nr/water/aquastat } \\
\text { Ldata/query/results.html } \\
\text { Source: FAO. 2016. AQUASTAT Main } \\
\text { Database, Food and Agriculture } \\
\text { Organization of the United Nations } \\
\text { (FAO). Website accessed on } \\
\text { [13/03/2019 8:28] }\end{array}$ & $10^{9} \mathrm{~m}^{3} /$ year & $\begin{array}{l}\text { Data available } \\
\text { from 1993-2017 } \\
\text { for } 93 \text { countries } \\
\text { with missing data } \\
\text { entries for most } \\
\text { years }\end{array}$ & Yes; indicator 6.3 .1 & $\begin{array}{l}\text { No, although data is } \\
\text { available for many } \\
\text { countries, the data is } \\
\text { missing for many } \\
\text { monitoring years } \\
\text { resulting in an } \\
\text { incomplete dataset. }\end{array}$ \\
\hline 25 & $\begin{array}{l}\text { Water } \\
\text { (SDG 6) }\end{array}$ & $\begin{array}{l}\text { Proportion of bodies } \\
\text { of water with good } \\
\text { ambient water } \\
\text { quality }\end{array}$ & $\begin{array}{l}\text { Percentage of water bodies (area) in a country with } \\
\text { good ambient water quality. "Good" indicates an } \\
\text { ambient water quality that does not damage } \\
\text { ecosystem function and human health according to } \\
\text { core ambient water quality parameters. Overall water } \\
\text { quality is estimated based on a core set of five } \\
\text { parameters that inform on major water quality } \\
\text { impairments present in many parts of the world: } \\
\text { electric conductivity/total dissolved solids; percentage } \\
\text { dissolved oxygen; dissolved inorganic nitrogen/total } \\
\text { nitrogen; dissolved inorganic phosphorus/total } \\
\text { phosphorus; and faecal coliform/Escherichia coli } \\
\text { bacteria (UNWater, 2016). }\end{array}$ & UNEP GEMStat & & $\begin{array}{l}\text { Initial baseline } \\
\text { data collected in } \\
2017 \text { for } \\
48 \text { countries. } \\
\text { Data is not } \\
\text { accessible yet }\end{array}$ & Yes; indicator 6.3.2 & $\begin{array}{l}\text { No, only baseline data } \\
\text { has been collected for } 48 \\
\text { countries. The baseline } \\
\text { data is not accessible } \\
\text { and cannot be used. }\end{array}$ \\
\hline 26 & $\begin{array}{l}\text { Water } \\
\text { (SDG 6) }\end{array}$ & $\begin{array}{l}\text { Change in water-use } \\
\text { efficiency over time }\end{array}$ & $\begin{array}{l}\text { Output from a given economic activity (based on ISIC } \\
\text { categories), per volume of net water withdrawn by the } \\
\text { economic activity. This indicator includes water use by } \\
\text { all economic activities, focusing on agriculture } \\
\text { (excluding the portion generated by rain-fed } \\
\text { agriculture), manufacturing, electricity, and water } \\
\text { collection, treatment and supply (looking at } \\
\text { distribution efficiency and capturing network } \\
\text { leakages). By assessing changes over time, the sectoral } \\
\text { values can be aggregated into one (UNWater, 2016). }\end{array}$ & $\begin{array}{l}\text { http://www.fao.org/nr/water/aquastat } \\
\text { Ldata/query/results.html }\end{array}$ & $\mathrm{USD} / \mathrm{m}^{3}$ & $\begin{array}{l}\text { Data can be } \\
\text { calculated from } \\
\text { water used per } \\
\text { sector and } \\
\text { economic } \\
\text { contribution, but } \\
\text { data specific for } \\
\text { this indicator is } \\
\text { not available. }\end{array}$ & Yes; indicator 6.4 .1 & $\begin{array}{l}\text { No; this indicator is } \\
\text { calculated per economic } \\
\text { sector in a country and } \\
\text { not as one value per } \\
\text { country. }\end{array}$ \\
\hline 27 & $\begin{array}{l}\text { Water } \\
\text { (SDG 6) }\end{array}$ & $\begin{array}{l}\text { Degree of } \\
\text { integrated water } \\
\text { resources }\end{array}$ & $\begin{array}{l}\text { The degree to which IWRM is implemented, by } \\
\text { assessing the four components of policies, institutions, } \\
\text { management tools and financing. It takes into account }\end{array}$ & $\begin{array}{l}\text { http://iwrmdataportal.unepdhi.org/dat } \\
\text { aoverview.html }\end{array}$ & $\%$ & $\begin{array}{l}\text { Data is available } \\
\text { for } 2017 \text { for } 175 \\
\text { countries. }\end{array}$ & Yes; indicator 6.5 .1 & $\begin{array}{l}\text { Yes; IWRM } \\
\text { implementation provides } \\
\text { a good indication of }\end{array}$ \\
\hline
\end{tabular}




\begin{tabular}{|c|c|c|c|c|c|c|c|c|}
\hline & & $\begin{array}{l}\text { management } \\
\text { implementation (0- } \\
\text { 100) }\end{array}$ & $\begin{array}{l}\text { the various users and uses of water, with the aim of } \\
\text { promoting positive social, economic and } \\
\text { environmental impacts at all levels, including the } \\
\text { transboundary level, where appropriate (UNWater, } \\
\text { 2016). }\end{array}$ & & & & & $\begin{array}{l}\text { water governance, and } \\
\text { has a strong correlation } \\
\text { with the implementation } \\
\text { of basic drinking water } \\
\text { and sanitation facilities. }\end{array}$ \\
\hline 28 & $\begin{array}{l}\text { Water } \\
\text { (SDG 6) }\end{array}$ & $\begin{array}{l}\text { Proportion of } \\
\text { transboundary basin } \\
\text { area with an } \\
\text { operational } \\
\text { arrangement for } \\
\text { water cooperation }\end{array}$ & $\begin{array}{l}\text { Percentage of transboundary basin area within a } \\
\text { country that has an operational agreement or other } \\
\text { arrangement for water cooperation. For the purpose of } \\
\text { the indicator, "basin area" is defined for surface waters } \\
\text { as the extent of the catchment, and for groundwater as } \\
\text { the extent of the aquifer. An "arrangement for water } \\
\text { cooperation" is a bilateral or multilateral treaty, } \\
\text { convention, agreement or other formal arrangement } \\
\text { among riparian countries that provides a framework } \\
\text { for cooperation on transboundary water management. } \\
\text { The criteria for the arrangement to be considered } \\
\text { "operational" are based on key aspects of substantive } \\
\text { cooperation in water management, such as the } \\
\text { existence of institutional mechanisms, regular } \\
\text { communication among riparian countries, joint or } \\
\text { coordinated management plans or objectives, as well } \\
\text { as a regular exchange of data and information } \\
\text { (UNWater, 2016). }\end{array}$ & http://geftwap.org/data-portal & $\%$ & $\begin{array}{l}\text { Data is not } \\
\text { included in the } \\
\text { National } \\
\text { Statistical Systems } \\
\text { yet. }\end{array}$ & Yes; indicator 6.5.2 & $\begin{array}{l}\text { No; there is no usable } \\
\text { data available yet, but } \\
\text { this indicator will play an } \\
\text { important role in terms } \\
\text { of catchment } \\
\text { management. }\end{array}$ \\
\hline 29 & $\begin{array}{l}\text { Water } \\
\text { (SDG 6) }\end{array}$ & $\begin{array}{l}\text { Change in the } \\
\text { extent of water- } \\
\text { related ecosystems } \\
\text { over time }\end{array}$ & $\begin{array}{l}\text { Changes over time in (1) the spatial extent of water- } \\
\text { related ecosystems (wetlands, forests and drylands); } \\
\text { (2) the quantity of water in ecosystems (rivers, lakes } \\
\text { and groundwater); and (3) the resulting health of } \\
\text { ecosystems. In addition, indicator } 6.3 .2 \text { on ambient } \\
\text { water quality and indicator } 6.4 .2 \text { on environmental } \\
\text { water requirements are critically important for } \\
\text { understanding ecosystems and need to be factored } \\
\text { into the assessment of indicator } 6.6 .1 \text { (UNWater, } \\
\text { 2016). }\end{array}$ & Not available yet & - & $\begin{array}{l}\text { Data not available } \\
\text { or not easily } \\
\text { accessible. }\end{array}$ & Yes; indicator 6.6 .1 & $\begin{array}{l}\text { No, insufficient data at } \\
\text { this time. }\end{array}$ \\
\hline 30 & $\begin{array}{l}\text { Water } \\
\text { (SDG 6) }\end{array}$ & $\begin{array}{l}\text { Amount of water- } \\
\text { and sanitation- } \\
\text { related official } \\
\text { development } \\
\text { assistance that is } \\
\text { part of a } \\
\text { government- } \\
\text { coordinated } \\
\text { spending plan }\end{array}$ & $\begin{array}{l}\text { Amount and percentage of ODA that is included in a } \\
\text { government coordinated spending plan, whether: (1) } \\
\text { on treasury or (2) on budget. ODA flows are official } \\
\text { financing with the main objective of promoting } \\
\text { economic development and welfare of developing } \\
\text { countries; they are concessional in character with a } \\
\text { grant element of at least } 25 \% \text {. By convention, ODA } \\
\text { flows comprise contributions from donor government } \\
\text { agencies, at all levels, to developing countries, either } \\
\text { bilaterally or through multilateral institutions. A } \\
\text { government coordinated spending plan is defined as a } \\
\text { financing plan/budget for water and sanitation } \\
\text { projects, clearly assessing the available sources of } \\
\text { finance and strategies for financing future needs } \\
\text { (UNWater, 2016). }\end{array}$ & $\begin{array}{l}\text { https://datacatalog.worldbank.org/ } \\
\text { Source: The World Bank }\end{array}$ & $\begin{array}{l}\text { US\$ per } \\
\text { year }\end{array}$ & $\begin{array}{l}\text { Data available } \\
\text { from } 2002-2011 \\
\text { for } 59 \text { countries }\end{array}$ & Yes; indicator 6.a.1 & $\begin{array}{l}\text { No; data is specific to } \\
\text { developing countries } \\
\text { and only covers } 59 \\
\text { countries which is } \\
\text { inefficient for the } \\
\text { purpose of developing } \\
\text { the WEF nexus index. }\end{array}$ \\
\hline 31 & $\begin{array}{l}\text { Water } \\
\text { (SDG 6) }\end{array}$ & $\begin{array}{l}\text { Proportion of local } \\
\text { administrative units } \\
\text { with established } \\
\text { and operational }\end{array}$ & $\begin{array}{l}\text { Percentage of local administrative units within a } \\
\text { country with established and operational policies and } \\
\text { procedures for participation of local communities in } \\
\text { water and sanitation management. Local }\end{array}$ & Not available & $\%$ & None & Yes; indicator 6.b.1 & $\begin{array}{l}\text { No; there is no usable } \\
\text { data available yet. }\end{array}$ \\
\hline
\end{tabular}




\begin{tabular}{|c|c|c|c|c|c|c|c|c|}
\hline & & $\begin{array}{l}\text { policies and } \\
\text { procedures for } \\
\text { participation of local } \\
\text { communities in } \\
\text { water and } \\
\text { sanitation } \\
\text { management }\end{array}$ & $\begin{array}{l}\text { administrative units refer to subdistricts, } \\
\text { municipalities, communes or other local community } \\
\text { level units covering both urban and rural areas to be } \\
\text { defined by the government. Policies and procedures } \\
\text { for participation of local communities in water and } \\
\text { sanitation management define a mechanism by which } \\
\text { individuals and communities can meaningfully } \\
\text { contribute to decisions and directions on water and } \\
\text { sanitation management (UNWater, 2016). }\end{array}$ & & & & & \\
\hline 32 & $\begin{array}{l}\text { Water } \\
\text { (SDG 6) }\end{array}$ & $\begin{array}{l}\text { Average } \\
\text { evapotranspiration } \\
\text { in volume ( } \mathrm{mm} \text { per } \\
\text { year) }\end{array}$ & $\begin{array}{l}\text { Important for water management policies in arid } \\
\text { countries. Would affect water allocation }\end{array}$ & $\begin{array}{l}\text { http://data.un.org/Data.aspx?d=ENV\&f } \\
\text { =variablelD\%3A7 } \\
\text { Source: United Nations Statistics } \\
\text { Division }\end{array}$ & $\begin{array}{l}\text { Million } \\
\mathrm{m}^{3} / \text { annum }\end{array}$ & $\begin{array}{l}\text { 1990-2015 } \\
\text { Fair coverage } \\
\text { Data available for } \\
\text { approximately } 64 \\
\text { countries }\end{array}$ & No & $\begin{array}{l}\text { No; data is only available } \\
\text { for } 64 \text { countries. The } \\
\text { JRC-COIN guideline is } \\
\text { that at an indicator level } \\
65 \% \text { of countries should } \\
\text { have valid data. }\end{array}$ \\
\hline 33 & $\begin{array}{l}\text { Water } \\
\text { (SDG 6) }\end{array}$ & $\begin{array}{l}\text { Dam storage } \\
\text { capacity }\end{array}$ & $\begin{array}{l}\text { Water storage capacity as a proxy for ability to manage } \\
\text { Rainfall variability between seasons. Underscores the } \\
\text { importance of a basic platform of hydraulic } \\
\text { infrastructure, but insensitive application may } \\
\text { encourage 'hydraulic mission' and heavy engineering at } \\
\text { the expense of other solutions }\end{array}$ & $\begin{array}{l}\text { http://www.fao.org/nr/water/aquastat } \\
\text { /data/query/index.html } \\
\text { Source: FAO. 2016. AQUASTAT Main } \\
\text { Database, Food and Agriculture } \\
\text { Organization of the United Nations } \\
\text { (FAO). Website accessed on } \\
\text { [13/03/2019 8:28] }\end{array}$ & $\mathrm{km}^{3}$ & $\begin{array}{l}\text { Data available } \\
\text { from } 1990-2017 \\
\text { for } 130 \text { countries, } \\
\text { with missing data } \\
\text { for some years. }\end{array}$ & No & $\begin{array}{l}\text { No; although there is } \\
\text { data per country } \\
\text { available, it is } \\
\text { fragmented. Also, it is } \\
\text { uncertain whether dam } \\
\text { storage is positive or } \\
\text { negative, since there is a } \\
\text { conflict between system } \\
\text { flows and storage }\end{array}$ \\
\hline 34 & $\begin{array}{l}\text { Water } \\
\text { (SDG 6) }\end{array}$ & $\begin{array}{l}\text { Virtual water } \\
\text { footprint }\end{array}$ & $\begin{array}{l}\text { Many potential policy applications and implications, } \\
\text { e.g. could be used to focus attention on the potential } \\
\text { for virtual water trade to mitigate against localised } \\
\text { water scarcity, but thinking is relatively young and } \\
\text { virtual water footprint data needs careful } \\
\text { interpretation }\end{array}$ & $\begin{array}{l}\text { Mekonnen, M.M. and Hoekstra, A.Y. } \\
\text { (2010) The green, blue and grey water } \\
\text { footprint of crops and derived crop } \\
\text { products, Value of Water Research } \\
\text { Report Series No. 47, UNESCO-IHE, } \\
\text { Delft, the Netherlands. } \\
\text { http://www.waterfootprint.org/Reports } \\
\text { Report47-WaterFootprintCrops- } \\
\text { Vol1.pdf } \\
\text { Source: Water Footprint Network }\end{array}$ & $\begin{array}{l}\text { ton of crop } \\
\text { or derived } \\
\text { crop } \\
\text { product }\end{array}$ & $\begin{array}{l}\text { 1996-2005 } \\
\text { (collated data) }\end{array}$ & No & $\begin{array}{l}\text { No; data is available, but } \\
\text { it has been collated into } \\
\text { a single dataset instead } \\
\text { of data per country. }\end{array}$ \\
\hline 35 & $\begin{array}{l}\text { Water } \\
\text { (SDG 6) }\end{array}$ & $\begin{array}{l}\text { Total agricultural } \\
\text { water managed } \\
\text { area }\end{array}$ & $\begin{array}{l}\text { Sum of total area equipped for irrigation and areas } \\
\text { with other forms of agricultural water management } \\
\text { (non-equipped flood recession cropping area and non- } \\
\text { equipped cultivated wetlands and inland valley } \\
\text { bottoms) (FAO, 2019-03-13) }\end{array}$ & $\begin{array}{l}\text { http://www.fao.org/nr/water/aquastat } \\
\text { Ldata/query/index.html } \\
\text { Source: FAO. 2016. AQUASTAT Main } \\
\text { Database, Food and Agriculture } \\
\text { Organization of the United Nations } \\
\text { (FAO). Website accessed on } \\
\text { [13/03/2019 8:28] }\end{array}$ & 1000 ha & $\begin{array}{l}\text { Data available } \\
\text { from } 1988-2017 \\
\text { for } 52 \text { countries, } \\
\text { with missing data } \\
\text { for some years. }\end{array}$ & No & $\begin{array}{l}\text { No; data is only available } \\
\text { for } 52 \text { countries. The } \\
\text { JRC-COIN guideline is } \\
\text { that at an indicator level } \\
65 \% \text { of countries should } \\
\text { have valid data. }\end{array}$ \\
\hline 36 & $\begin{array}{l}\text { Water } \\
\text { (SDG 6) }\end{array}$ & $\begin{array}{l}\text { Population affected } \\
\text { by water related } \\
\text { diseases }\end{array}$ & $\begin{array}{l}\text { Three types of water-related diseases exist: (i) water- } \\
\text { borne diseases are those diseases that arise from } \\
\text { infected water and are transmitted when the water is } \\
\text { used for drinking or cooking (for example cholera, } \\
\text { typhoid); (ii) water-based diseases are those in which } \\
\text { water provides the habitant for host organisms of } \\
\text { parasites ingested (for example shistomasomiasis or } \\
\text { bilharzia); (iii) water-related insect vector diseases are } \\
\text { those in which insect vectors rely on water as habitat } \\
\text { but transmission is not through direct contact with }\end{array}$ & $\begin{array}{l}\text { http://www.fao.org/nr/water/aquastat } \\
\text { data/query/index.html } \\
\text { Source: FAO. 2016. AQUASTAT Main } \\
\text { Database, Food and Agriculture } \\
\text { Organization of the United Nations } \\
\text { (FAO). Website accessed on } \\
\text { [13/03/2019 8:28] }\end{array}$ & $\begin{array}{l}1000 \\
\text { inhabitants }\end{array}$ & $\begin{array}{l}\text { Data available } \\
\text { from } 1992-2011 \\
\text { for } 32 \text { countries, } \\
\text { with most data } \\
\text { missing for some } \\
\text { years. }\end{array}$ & No & $\begin{array}{l}\text { No; data is only available } \\
\text { for } 32 \text { countries. The } \\
\text { JRC-COIN guideline is } \\
\text { that at an indicator level } \\
65 \% \text { of countries should } \\
\text { have valid data. }\end{array}$ \\
\hline
\end{tabular}




\begin{tabular}{|c|c|c|c|c|c|c|c|c|}
\hline & & & $\begin{array}{l}\text { water (for example malaria, onchocerciasis or river } \\
\text { blindness, elephantiasis). }\end{array}$ & & & & & \\
\hline 37 & $\begin{array}{l}\text { Energy } \\
\text { (SDG 7) }\end{array}$ & $\begin{array}{l}\text { Access to electricity } \\
\text { (\% of the } \\
\text { population) }\end{array}$ & $\begin{array}{l}\text { Access to electricity is the percentage of population } \\
\text { with access to electricity. Electrification data are } \\
\text { collected from industry, national surveys and } \\
\text { international sources (World Bank 2019-03-04) }\end{array}$ & $\begin{array}{l}\text { https://data.worldbank.org/indicator/E } \\
\text { G.ELC.ACCS.ZS?view=chart } \\
\text { Source: World Bank, Sustainable } \\
\text { Energy for All (SE4ALL) database from } \\
\text { the SE4ALL Global Tracking Framework } \\
\text { led jointly by the World Bank, } \\
\text { International Energy Agency, and the } \\
\text { Energy Sector Management Assistance } \\
\text { Program. }\end{array}$ & $\%$ & $\begin{array}{l}2016 \\
\text { Very good data } \\
\text { coverage. } \\
\text { Indicator utilised } \\
\text { in SDG Index for } \\
\text { SDG } 7\end{array}$ & $\begin{array}{l}\text { Yes, Indicator 7.1.1 } \\
\text { (C070101) }\end{array}$ & $\begin{array}{l}\text { Yes; essential indicator } \\
\text { for SDG } 7 \text { with good data } \\
\text { coverage. }\end{array}$ \\
\hline 38 & $\begin{array}{l}\text { Energy } \\
\text { (SDG 7) }\end{array}$ & $\begin{array}{l}\text { Renewable energy } \\
\text { consumption (\% of } \\
\text { total final energy } \\
\text { consumption) }\end{array}$ & $\begin{array}{l}\text { Renewable energy consumption is the share of } \\
\text { renewables energy in total final energy consumption } \\
\text { (World Bank 2019-03-04). }\end{array}$ & $\begin{array}{l}\text { https://data.worldbank.org/indicator/E } \\
\text { G.FEC.RNEW.ZS } \\
\text { Source: World Bank, Sustainable Energy } \\
\text { for All (SE4ALL) database from the } \\
\text { SE4ALL Global Tracking Framework led } \\
\text { jointly by the World Bank, International } \\
\text { Energy Agency, and the Energy Sector } \\
\text { Management Assistance Program. }\end{array}$ & $\%$ & $\begin{array}{l}2015 \\
\text { Very good data } \\
\text { coverage. } \\
\text { Indicator utilised } \\
\text { in SDG Index for } \\
\text { SDG } 7\end{array}$ & $\begin{array}{l}\text { Yes, Indicator 7.2.1 } \\
\text { (C070201) }\end{array}$ & $\begin{array}{l}\text { Yes; essential indicator } \\
\text { for SDG } 7 \text { with good data } \\
\text { coverage. }\end{array}$ \\
\hline 39 & $\begin{array}{l}\text { Energy } \\
\text { (SDG 7) }\end{array}$ & $\begin{array}{l}\text { Renewable } \\
\text { electricity output (\% } \\
\text { of total electricity } \\
\text { output) }\end{array}$ & $\begin{array}{l}\text { Renewable electricity is the share of electricity } \\
\text { generated by renewable power plants in total } \\
\text { electricity generated by all types of plants (World Bank } \\
\text { 2019-03-04). }\end{array}$ & $\begin{array}{l}\text { https://data.worldbank.org/indicator/E } \\
\text { G.ELC.RNEW.ZS?view=chart } \\
\text { Source: IEA Statistics @ OECD/IEA } 2018 \\
\text { (http://www.iea.org/stats/index.asp) }\end{array}$ & $\%$ & $\begin{array}{l}2015 \\
\text { Very good data } \\
\text { coverage }\end{array}$ & No & $\begin{array}{l}\text { Yes; since "Renewable } \\
\text { energy consumption" } \\
\text { refers to energy, while } \\
\text { this indicator considers } \\
\text { electricity only. } \\
\text { Correlation with } \\
\text { Renewable energy } \\
\text { consumption is good, } \\
\text { but not too high } \\
\end{array}$ \\
\hline 40 & $\begin{array}{l}\text { Energy } \\
\text { (SDG 7) }\end{array}$ & $\begin{array}{l}\text { Total greenhouse } \\
\text { gas emissions (kt of } \\
\mathrm{CO}_{2} \text { equivalent) }\end{array}$ & $\begin{array}{l}\text { Total greenhouse gas emissions in kt of } \mathrm{CO}_{2} \text { equivalent } \\
\text { are composed of } \mathrm{CO}_{2} \text { totals excluding short-cycle } \\
\text { biomass burning (such as agricultural waste burning } \\
\text { and Savannah burning) but including other biomass } \\
\text { burning (such as forest fires, post-burn decay, peat } \\
\text { fires and decay of drained peatlands), all } \\
\text { anthropogenic } \mathrm{CH}_{4} \text { sources, } \mathrm{N}_{2} \mathrm{O} \text { sources and F-gases } \\
\text { (HFCs, PFCs and } \mathrm{SF} 6 \text { ). (World Bank 2019-03-04) }\end{array}$ & $\begin{array}{l}\text { https://data.worldbank.org/indicator/E } \\
\text { N.ATM.GHGT.KT.CE?view=chart } \\
\text { Source: European Commission, Joint } \\
\text { Research Centre (JRC)/Netherlands } \\
\text { Environmental Assessment Agency } \\
\text { (PBL). Emission Database for Global } \\
\text { Atmospheric Research (EDGAR), } \\
\text { EDGARv4.2 FT2012: } \\
\text { http://edgar.jrc.ec.europa.eu/ }\end{array}$ & $\begin{array}{l}\mathrm{kt} \text { of } \mathrm{CO}_{2} \\
\text { equivalent }\end{array}$ & $\begin{array}{l}2012 \\
\text { Very good data } \\
\text { coverage }\end{array}$ & No & $\begin{array}{l}\text { No; since this indicator } \\
\text { represents all of the } \\
\text { GHGs as } \mathrm{CO}_{2} \text { equivalent } \\
\text { and includes biomass } \\
\text { burning, methane, and } \\
\text { other non-energy } \\
\text { related GHG sources. }\end{array}$ \\
\hline 41 & $\begin{array}{l}\text { Energy } \\
\text { (SDG 7) }\end{array}$ & $\begin{array}{l}\mathrm{CO}_{2} \text { emissions } \\
\text { (metric tons per } \\
\text { capita) }\end{array}$ & $\begin{array}{l}\text { Carbon dioxide emissions are those stemming from the } \\
\text { burning of fossil fuels and the manufacture of cement. } \\
\text { They include carbon dioxide produced during } \\
\text { consumption of solid, liquid, and gas fuels and gas } \\
\text { flaring (World Bank 2019-03-05). }\end{array}$ & $\begin{array}{l}\text { https://data.worldbank.org/indicator/E } \\
\text { N.ATM.CO2E.PC } \\
\text { Source: Carbon Dioxide Information } \\
\text { Analysis Centre, Environmental Sciences } \\
\text { Division, Oak Ridge National Laboratory, } \\
\text { Tennessee, United States. } \\
\text { https://data.worldbank.org/indicator/E } \\
\text { N.ATM.CO2E.PC }\end{array}$ & $\begin{array}{l}\text { metric tons } \\
\text { per capita }\end{array}$ & $\begin{array}{l}2014 \\
\text { Very good data } \\
\text { coverage. Similar } \\
\text { indicator utilised } \\
\text { in SDG Index for } \\
\text { SDG } 7\end{array}$ & No & $\begin{array}{l}\text { Yes; this data provides } \\
\text { an indication of fossil } \\
\text { fuel-related power } \\
\text { generation. The per } \\
\text { capita rating takes } \\
\text { cognisance of the size of } \\
\text { the impact relative to } \\
\text { the population }\end{array}$ \\
\hline 42 & $\begin{array}{l}\text { Energy } \\
\text { (SDG 7) }\end{array}$ & $\mathrm{CO}_{2}$ emissions (kt) & $\begin{array}{l}\text { Carbon dioxide emissions are those stemming from the } \\
\text { burning of fossil fuels and the manufacture of cement. } \\
\text { They include carbon dioxide produced during } \\
\text { consumption of solid, liquid, and gas fuels and gas } \\
\text { flaring (World Bank 2019-03-05). }\end{array}$ & $\begin{array}{l}\text { https://data.worldbank.org/indicator/E } \\
\text { N.ATM.CO2E.KT?view=chart Source: } \\
\text { Carbon Dioxide Information Analysis } \\
\text { Centre, Environmental Sciences } \\
\text { Division, Oak Ridge National Laboratory, } \\
\text { Tennessee, United States. }\end{array}$ & kt & $\begin{array}{l}2014 \text { Very good } \\
\text { data coverage }\end{array}$ & No & $\begin{array}{l}\text { No; same parameter } \\
\text { being measured as } \mathrm{CO} 2 \\
\text { emissions (metric tons } \\
\text { per capita), except that } \\
\text { this is not per capita, but } \\
\text { the quantum per } \\
\text { country. }\end{array}$ \\
\hline
\end{tabular}




\begin{tabular}{|c|c|c|c|c|c|c|c|c|}
\hline 43 & $\begin{array}{l}\text { Energy } \\
\text { (SDG 7) }\end{array}$ & $\begin{array}{l}\text { Energy use (kg of oil } \\
\text { equivalent per } \\
\text { capita) }\end{array}$ & $\begin{array}{l}\text { Energy use refers to use of primary energy before } \\
\text { transformation to other end-use fuels, which is equal } \\
\text { to indigenous production plus imports and stock } \\
\text { changes, minus exports and fuels supplied to ships and } \\
\text { aircraft engaged in international transport (World Bank } \\
\text { 2019-03-05). }\end{array}$ & $\begin{array}{l}\text { https://data.worldbank.org/indicator/E } \\
\text { G.USE.PCAP.KG.OE?view=chart } \\
\text { Source: IEA Statistics @ OECD/IEA 2014 } \\
\text { (http://www.iea.org/stats/index.asp) }\end{array}$ & $\begin{array}{l}\text { kg of oil } \\
\text { equivalent } \\
\text { per capita }\end{array}$ & $\begin{array}{l}2015,2014,2013 \\
\text { Good data } \\
\text { coverage, } \\
\text { although will need } \\
\text { to utilise latest } \\
\text { data since very } \\
\text { limited data for } \\
2015 .\end{array}$ & $\begin{array}{l}\text { No, but consider } \\
\text { including } 7.1 .2 \\
\text { "Proportion of } \\
\text { population with } \\
\text { primary reliance } \\
\text { on clean fuels and } \\
\text { technology" }\end{array}$ & $\begin{array}{l}\text { No; although this is a } \\
\text { relevant indicator with } \\
\text { readily available data it } \\
\text { has a very high } \\
\text { correlation (0.94) with } \\
\text { electric power } \\
\text { consumption per capita, } \\
\text { and would therefore } \\
\text { constitute 'double } \\
\text { accounting'. It is } \\
\text { therefore excluded }\end{array}$ \\
\hline 44 & $\begin{array}{l}\text { Energy } \\
\text { (SDG 7) }\end{array}$ & $\begin{array}{l}\text { Energy imports, net } \\
\text { (\% of energy use) }\end{array}$ & $\begin{array}{l}\text { Net energy imports are estimated as energy use less } \\
\text { production, both measured in oil equivalents. A } \\
\text { negative value indicates that the country is a net } \\
\text { exporter. Energy use refers to use of primary energy } \\
\text { before transformation to other end-use fuels, which is } \\
\text { equal to indigenous production plus imports and stock } \\
\text { changes, minus exports and fuels supplied to ships and } \\
\text { aircraft engaged in international transport (World Bank } \\
\text { 2019-03-05). }\end{array}$ & $\begin{array}{l}\text { https://data.worldbank.org/indicator/E } \\
\text { G.IMP.CONS.ZS?view=chart } \\
\text { Source: IEA Statistics @ OECD/IEA 2014 } \\
\text { (http://www.iea.org/stats/index.asp) }\end{array}$ & $\%$ & $\begin{array}{l}2015,2014,2013 \\
\text { Good data } \\
\text { coverage, } \\
\text { although will need } \\
\text { to utilise latest } \\
\text { data since very } \\
\text { limited data for } \\
2015 .\end{array}$ & No & $\begin{array}{l}\text { Yes; this indicator } \\
\text { provides a helpful } \\
\text { indication of national } \\
\text { energy security. But this } \\
\text { indicator will be } \\
\text { truncated at zero to } \\
\text { exclude exports, since } \\
\text { the primary concern is } \\
\text { energy security and the } \\
\text { indicator is essentially } \\
\text { measuring imports and } \\
\text { exports. }\end{array}$ \\
\hline 45 & $\begin{array}{l}\text { Energy } \\
\text { (SDG 7) }\end{array}$ & $\begin{array}{l}\text { Firms experiencing } \\
\text { electrical outages (\% } \\
\text { of firms) }\end{array}$ & $\begin{array}{l}\text { Percent of firms experiencing electrical outages during } \\
\text { the previous fiscal year (World Bank 2019-03-05). }\end{array}$ & $\begin{array}{l}\text { https://data.worldbank.org/indicator/IC } \\
\text {.ELC.OUTG.ZS } \\
\text { Source: World Bank, Enterprise Surveys }\end{array}$ & $\%$ & $\begin{array}{l}\text { 2013-2017 } \\
\text { Relatively poor } \\
\text { data coverage. } \\
\text { Will need to use } \\
\text { the latest value }\end{array}$ & No & $\begin{array}{l}\text { No, relatively poor data } \\
\text { coverage. }\end{array}$ \\
\hline 46 & $\begin{array}{l}\text { Energy } \\
\text { (SDG 7) }\end{array}$ & $\begin{array}{l}\text { Electric power } \\
\text { consumption (kWh } \\
\text { per capita) }\end{array}$ & $\begin{array}{l}\text { Electric power consumption measures the production } \\
\text { of power plants and combined heat and power plants } \\
\text { less transmission, distribution, and transformation } \\
\text { losses and own use by heat and power plants (World } \\
\text { Bank 2019-03-05). }\end{array}$ & $\begin{array}{l}\text { https://data.worldbank.org/indicator/E } \\
\text { G.USE.ELEC.KH.PC?view=chart } \\
\text { Source: IEA Statistics @ OECD/IEA } 2014 \\
\text { (http://www.iea.org/stats/index.asp) }\end{array}$ & $\begin{array}{l}\text { kWh per } \\
\text { capita }\end{array}$ & $\begin{array}{l}2014 \\
\text { Very good data } \\
\text { coverage }\end{array}$ & No & $\begin{array}{l}\text { Yes; very good data } \\
\text { coverage and very } \\
\text { relevant, since it } \\
\text { provides a helpful } \\
\text { indication of a nation's } \\
\text { generation capacity. }\end{array}$ \\
\hline 47 & $\begin{array}{l}\text { Energy } \\
\text { (SDG 7) }\end{array}$ & $\begin{array}{l}\text { Proportion of } \\
\text { population with } \\
\text { primary reliance on } \\
\text { clean fuels and } \\
\text { technology }\end{array}$ & $\begin{array}{l}\text { This is measured as the share of the total population } \\
\text { with access to clean fuels and technologies for cooking. } \\
\text { Access to clean fuels or technologies such as clean } \\
\text { cookstoves reduce exposure to indoor air pollutants, a } \\
\text { leading cause of death in low-income households (UN } \\
\text { Stats, 2018) }\end{array}$ & $\begin{array}{l}\text { Households that use solid fuels for } \\
\text { cooking: } \\
\text { http://apps.who.int/gho/data/view.mai } \\
\text { n.vEQSOLIDFUELSTOTV } \\
\text { Source: World Health Organization } \\
\text { (MICS and DHS) }\end{array}$ & $\%$ & $\begin{array}{l}\text { Data available } \\
\text { from } 1998-2013 \\
\text { for } 93 \text { countries, } \\
\text { with data missing } \\
\text { for some years. }\end{array}$ & Yes; indicator 7.1.2 & $\begin{array}{l}\text { No; data is only available } \\
\text { for } 93 \text { countries. The } \\
\text { JRC-COIN guideline is } \\
\text { that at an indicator level } \\
65 \% \text { of countries should } \\
\text { have valid data. }\end{array}$ \\
\hline 48 & $\begin{array}{l}\text { Energy } \\
\text { (SDG 7) }\end{array}$ & $\begin{array}{l}\text { Energy intensity } \\
\text { measured in terms } \\
\text { of primary energy } \\
\text { and GDP }\end{array}$ & $\begin{array}{l}\text { This is measured as the energy intensity of economies } \\
\text { (collectively across all sectors). Energy intensity is } \\
\text { measured as the quantity of kilowatt-hours produced } \\
\text { per } 2011 \text { international-\$ of gross domestic product } \\
\text { (kWh per } 2011 \text { int-\$) (UN Stats, 2018). } \\
\text { Total primary energy supply is defined as the sum of } \\
\text { production and imports subtracting exports and } \\
\text { storage changes. }\end{array}$ & $\begin{array}{l}\text { https://www.iea.org/statistics/?country } \\
=\text { WORLD\&year=2016\&category=Energy } \\
\text { \%20supply\&indicator=TPESbyGDP\&mo } \\
\text { de=map\&dataTable=BALANCES } \\
\text { Source: International Energy Agency }\end{array}$ & TPES/GDP & $\begin{array}{l}\text { Data available for } \\
2016 \text { for } 142 \\
\text { countries, with } \\
\text { data missing for } \\
\text { some years. }\end{array}$ & Yes; indicator 7.3.1 & $\begin{array}{l}\text { No; this indicator is an } \\
\text { SDG indicator and data } \\
\text { are available for } 142 \\
\text { countries, but it has a } \\
\text { negative, low correlation } \\
\text { with all other indicators } \\
\text { associated with } \\
\text { availability. }\end{array}$ \\
\hline 49 & $\begin{array}{l}\text { Energy } \\
\text { (SDG 7) }\end{array}$ & $\begin{array}{l}\text { International } \\
\text { financial flows to } \\
\text { developing } \\
\text { countries in support }\end{array}$ & $\begin{array}{l}\text { The flows covered by the OECD are defined as all } \\
\text { official loans, grants and equity investments received } \\
\text { by countries on the DAC List of ODA Recipients from } \\
\text { foreign governments and multilateral agencies, for the }\end{array}$ & $\begin{array}{l}\text { http://resourceirena.irena.org/gateway } \\
\text { dashboard/?topic }=6 \& \text { subTopic }=8 \\
\text { Source: International Renewable Energy } \\
\text { Agency }\end{array}$ & Million USD & $\begin{array}{l}\text { Data is available } \\
\text { from } 2006-2017 \\
\text { for } 141 \text { countries }\end{array}$ & Yes; indicator 7. a.1 & $\begin{array}{l}\text { No; although this } \\
\text { indicator is an SDG } \\
\text { indicator and data are } \\
\text { available for } 141\end{array}$ \\
\hline
\end{tabular}




\begin{tabular}{|c|c|c|c|c|c|c|c|c|}
\hline & & $\begin{array}{l}\text { of clean energy } \\
\text { research and } \\
\text { development and } \\
\text { renewable energy } \\
\text { production, } \\
\text { including in hybrid } \\
\text { systems }\end{array}$ & $\begin{array}{l}\text { purpose of clean energy research and development } \\
\text { and renewable energy production, including in hybrid } \\
\text { systems extracted from the OECD/DAC Creditor } \\
\text { Reporting System (CRS). } \\
\text { The flows covered by IRENA are defined as all } \\
\text { additional loans, grants and equity investments } \\
\text { received by developing countries (defined as countries } \\
\text { in developing regions, as listed in the UN M49 } \\
\text { composition of regions) from all foreign governments, } \\
\text { multilateral agencies and additional development } \\
\text { finance institutions (including export credits, where } \\
\text { available) for the purpose of clean energy research and } \\
\text { development and renewable energy production, } \\
\text { including in hybrid systems. These additional flows } \\
\text { cover the same technologies and other activities } \\
\text { (research and development, technical assistance, etc.) } \\
\text { as listed above and exclude all flows extracted from } \\
\text { the OECD/DAC CRS (UN Stats, 2018) }\end{array}$ & & & $\begin{array}{l}\text { with data missing } \\
\text { for some years. }\end{array}$ & & $\begin{array}{l}\text { countries } \\
\text { developed/donor and } \\
\text { developing countries } \\
\text { who have significant } \\
\text { domestic expenditure on } \\
\text { renewable energy } \\
\text { projects are 'penalised' } \\
\text { in the calculation of this } \\
\text { index. It was therefore } \\
\text { decided to exclude this } \\
\text { indicator from the } \\
\text { composite indicator }\end{array}$ \\
\hline 50 & $\begin{array}{l}\text { Energy } \\
\text { (SDG 7) }\end{array}$ & $\begin{array}{l}\text { Investments in } \\
\text { energy efficiency as } \\
\text { a percentage of GDP } \\
\text { and the amount of } \\
\text { foreign direct } \\
\text { investment in } \\
\text { financial transfer for } \\
\text { infrastructure and } \\
\text { technology to } \\
\text { sustainable } \\
\text { development } \\
\text { services }\end{array}$ & Not defined yet. & Not available & $\%$ & None & Yes; indicator 7. b.1 & $\begin{array}{l}\text { No; the definition for } \\
\text { this indicator is not yet } \\
\text { well defined and } \\
\text { therefore not well } \\
\text { understood yet. There is } \\
\text { no data easily available } \\
\text { for this indicator. }\end{array}$ \\
\hline 51 & $\begin{array}{l}\text { Energy } \\
\text { (SDG 7) }\end{array}$ & $\begin{array}{l}\text { Amount of fossil- } \\
\text { fuel subsidies per } \\
\text { unit of GDP } \\
\text { (production and } \\
\text { consumption) and } \\
\text { as a proportion of } \\
\text { total national } \\
\text { expenditure on } \\
\text { fossil fuels }\end{array}$ & $\begin{array}{l}\text { In order to measure fossil fuel subsidies at the national, } \\
\text { regional and global level, three sub-indicators are } \\
\text { recommended for reporting on this indicator: 1) direct } \\
\text { transfer of government funds; } 2 \text { ) induced transfers } \\
\text { (price support); and as an optional sub-indicator 3) tax } \\
\text { expenditure, other revenue foregone, and underpricing } \\
\text { of goods and services. The definitions of the IEA } \\
\text { Statistical Manual (IEA, 2005) and the Agreement on } \\
\text { Subsidies and Countervailing Measures (ASCM) under } \\
\text { the World Trade Organization (WTO) (WTO, 1994) are } \\
\text { used to define fossil fuel subsidies. Standardised } \\
\text { descriptions from the United Nations Statistical Office's } \\
\text { Central Product Classification should be used to classify } \\
\text { individual energy products. It is proposed to drop the } \\
\text { wording "as a proportion of total national expenditure } \\
\text { on fossil fuels" and thus this indicator is effectively } \\
\text { "Amount of fossil fuel subsidies per unit of GDP } \\
\text { (production and consumption)". (UN Stats, 2018) }\end{array}$ & Not available & USD/GDP & $\begin{array}{l}\text { None; baseline } \\
\text { assessment was } \\
\text { conducted. } \\
\text { Reporting on } \\
\text { induced transfers } \\
\text { started in 2018; } \\
\text { reporting on data } \\
\text { for direct } \\
\text { transfers and tax } \\
\text { revenue will take } \\
\text { place in } 2020 \text {. }\end{array}$ & Yes; indicator 12.c.1 & $\begin{array}{l}\text { No; no data readily } \\
\text { available }\end{array}$ \\
\hline
\end{tabular}




\begin{tabular}{|c|c|c|c|c|c|c|c|c|}
\hline 52 & $\begin{array}{l}\text { Food } \\
\text { (SDG 2) }\end{array}$ & $\begin{array}{l}\text { Prevalence of } \\
\text { undernourishment }{ }^{2}\end{array}$ & $\begin{array}{l}\text { The prevalence of undernourishment expresses the } \\
\text { probability that a randomly selected individual from } \\
\text { the population consumes a number of calories that is } \\
\text { insufficient to cover her/his energy requirement for an } \\
\text { active and healthy life. The indicator is computed by } \\
\text { comparing a probability distribution of habitual daily } \\
\text { dietary energy consumption with a threshold level } \\
\text { called the minimum dietary energy Requirement. Both } \\
\text { are based on the notion of an average individual in the } \\
\text { reference population (FAO 2019-03-05). }\end{array}$ & $\begin{array}{l}\text { http://www.fao.org/economic/ess/ess- } \\
\text { fs/ess-fadata/en/\#.WDmBh9V96Uk } \\
\text { Source: FAOSTAT and ESS calculations: }\end{array}$ & $\%$ & $\begin{array}{l}\text { 2015-2017 } \\
\text { Very good data } \\
\text { coverage. } \\
\text { Indicator utilised } \\
\text { in SDG Index for } \\
\text { SDG } 2\end{array}$ & $\begin{array}{l}\text { Yes, 2.1.1 (C020101). } \\
\text { Could consider a } \\
\text { health indicator such } \\
\text { as 3.2.1 "Under-5 } \\
\text { mortality rate" as an } \\
\text { additional indicator of } \\
\text { 'healthy' food? }\end{array}$ & $\begin{array}{l}\text { Yes; it was the official } \\
\text { Millennium } \\
\text { Development Goal } \\
\text { indicator for Goal } 1 \text {, } \\
\text { Target 1.9, and is now an } \\
\text { SDG indicator }\end{array}$ \\
\hline 53 & $\begin{array}{l}\text { Food } \\
\text { (SDG 2) }\end{array}$ & $\begin{array}{l}\text { Percentage of } \\
\text { children under } 5 \\
\text { years of age } \\
\text { affected by } \\
\text { wasting }^{34}\end{array}$ & $\begin{array}{l}\text { Wasting prevalence is the proportion of children under } \\
\text { five whose weight for height is more than two standard } \\
\text { deviations below the median for the international } \\
\text { reference population ages 0-59 months (FAO 2019-03- } \\
\text { 05). }\end{array}$ & $\begin{array}{l}\text { http://www.fao.org/economic/ess/ess- } \\
\text { fs/ess-fadata/en/\#.WDmBh9V96Uk } \\
\text { Source: World Development Indicators: } \\
\text { http://data.worldbank.org/indicator/SH } \\
\text {.STA.WAST.ZS } \\
\text { + UNICEF et al. (2016) report an average } \\
\text { prevalence of wasting in high-income } \\
\text { countries of } 0.75 \% \text {, which has been } \\
\text { assumed for high-income countries with } \\
\text { missing data. The classification as a } \\
\text { high-income country is based on the } \\
\text { World Bank's listing of high-income } \\
\text { countries: } \\
\text { https://data.worldbank.org/income- } \\
\text { level/high-income }\end{array}$ & $\%$ & $\begin{array}{l}2016 \\
\text { Limited data. } \\
\text { Need to utilise } \\
\text { latest since } \\
\text { coverage for the } \\
\text { final year alone is } \\
\text { scarce. Indicator } \\
\text { utilised in SDG } \\
\text { Index for SDG } 2\end{array}$ & No & $\begin{array}{l}\text { Yes; if there is a strong } \\
\text { correlation of data with } \\
\text { SDG indicator 2.2.1's } \\
\text { data, one of the two } \\
\text { indicators will be used to } \\
\text { avoid noise in the } \\
\text { dataset. However the } \\
\text { correlation is good, but } \\
\text { not too high. Both } \\
\text { indicators can therefore } \\
\text { be retained. }\end{array}$ \\
\hline 54 & $\begin{array}{l}\text { Food } \\
\text { (SDG 2) }\end{array}$ & $\begin{array}{l}\text { Percentage of } \\
\text { children under } 5 \\
\text { years of age who } \\
\text { are stunted }^{5}\end{array}$ & $\begin{array}{l}\text { Percentage of stunting (height-for-age less than }-2 \\
\text { standard deviations of the WHO Child Growth } \\
\text { Standards median) among children aged 0-59 months } \\
\text { (FAO 2019-03-05). }\end{array}$ & $\begin{array}{l}\text { http://www.fao.org/economic/ess/ess- } \\
\text { fs/ess-fadata/en/\#.WDmBh9V96Uk } \\
\text { Source: World Development Indicators: } \\
\text { http://data.worldbank.org/indicator/SH } \\
\text { STA.WAST.ZS + UNICEF et al. (2016) } \\
\text { report an average prevalence of } \\
\text { wasting in high income countries of } \\
\text { 2.58\%, which has been assumed for } \\
\text { high-income countries with missing } \\
\text { data. The classification as a high- } \\
\text { income country is based on the World } \\
\text { Bank's listing of high-income countries: } \\
\text { https://data.worldbank.org/income- } \\
\text { level/high-income }\end{array}$ & $\%$ & $\begin{array}{l}2016 \\
\text { Limited data. } \\
\text { Need to utilise } \\
\text { most recent } \\
\text { coverage for the } \\
\text { final year alone is } \\
\text { scarce. Indicator } \\
\text { utilised in SDG } \\
\text { Index for SDG } 2\end{array}$ & $\begin{array}{l}\text { Yes, 2.2.1 } \\
\text { (C020201) }\end{array}$ & $\begin{array}{l}\text { Yes; this is an SDG } \\
\text { indicator with sufficient } \\
\text { data available for } 153 \\
\text { countries. }\end{array}$ \\
\hline 55 & $\begin{array}{l}\text { Food } \\
\text { (SDG 2) }\end{array}$ & $\begin{array}{l}\text { The depth of the } \\
\text { food deficit }\end{array}$ & $\begin{array}{l}\text { The depth of the food deficit indicates how many } \\
\text { calories would be needed to lift the undernourished } \\
\text { from their status, everything else being constant. The }\end{array}$ & $\begin{array}{l}\text { http://www.fao.org/economic/ess/ess- } \\
\text { fs/ess-fadata/en/\#.WDmBh9V96Uk } \\
\text { Version } 15 \text { Sep } 2017\end{array}$ & $\begin{array}{l}\mathrm{kCal} / \\
\text { day }\end{array}$ & $\begin{array}{l}\text { 2014-2016 } \\
\text { Very good data } \\
\text { coverage. }\end{array}$ & No & $\begin{array}{l}\text { No-Many countries, } \\
\text { such as Denmark, } \\
\text { Finland, Switzerland, }\end{array}$ \\
\hline
\end{tabular}

2 "This is the traditional FAO hunger indicator, adopted as official Millennium Development Goal indicator for Goal 1, Target 1.9." (http://www.fao.org/economic/ess/ess-fs/ess-fadata/en/\#.WDmBh9V96Uk).

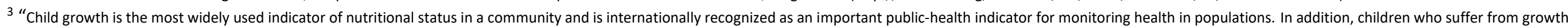
retardation as a result of poor diets and/or recurrent infections tend to have a greater risk of suffering illness and death." (http://www.fao.org/economic/ess/ess-fs/ess-fadata/en/\#.WDmBh9V96Uk)

${ }^{4}$ The "two official indicators for the hunger target [are] the prevalence of undernourishment and the proportion of underweight children under 5 years of age" (http://www.fao.org/3/a-i4671e.pdf)

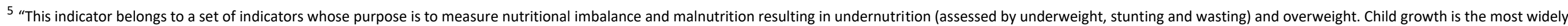

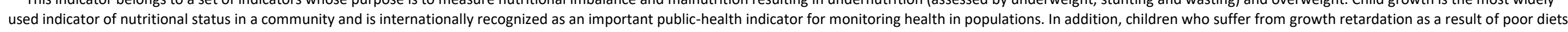
and/or recurrent infections tend to have a greater risk of suffering illness and death." (http://www.fao.org/economic/ess/ess-fs/ess-fadata/en/\#.WDmBh9V96Uk) 


\begin{tabular}{|c|c|c|c|c|c|c|c|c|}
\hline & & $\begin{array}{l}\text { (kilocalories per } \\
\text { person per day) }\end{array}$ & $\begin{array}{l}\text { average intensity of food deprivation of the } \\
\text { undernourished, estimated as the difference between } \\
\text { the average dietary energy requirement and the } \\
\text { average dietary energy consumption of the } \\
\text { undernourished population (food-deprived), is } \\
\text { multiplied by the number of undernourished to } \\
\text { provide an estimate of the total food deficit in the } \\
\text { country, which is then normalized by the total } \\
\text { population (World Bank 2019-03-06). }\end{array}$ & Source: ESS calculations & & & & $\begin{array}{l}\text { Sweden, Norway have } \\
\text { no data but are assumed } \\
\text { to be close to zero } \\
\text { (patched to } 2.5 \text { for } \\
\text { geometric mean). } \\
\text { Although this indicator } \\
\text { has very good data, it } \\
\text { has a very high } \\
\text { correlation with the } \\
\text { prevalence of } \\
\text { undernourishment } \\
\text { (0.95), and it has } \\
\text { therefore been excluded } \\
\text { in order to avoid double } \\
\text { accounting }\end{array}$ \\
\hline 56 & $\begin{array}{l}\text { Food } \\
\text { (SDG 2) }\end{array}$ & $\begin{array}{l}\text { Average protein } \\
\text { supply }{ }^{7}\end{array}$ & $\begin{array}{l}\text { National average protein supply (expressed in grams } \\
\text { per caput per day) (FAO 2019-03-06) }\end{array}$ & $\begin{array}{l}\text { http://www.fao.org/economic/ess/ess- } \\
\text { fs/ess-fadata/en/\#.WDmBh9V96Uk } \\
\text { Source: FAOSTAT }\end{array}$ & $\begin{array}{l}\text { gr/caput/da } \\
\text { y }\end{array}$ & $\begin{array}{l}\text { 2011-2013 } \\
\text { Very good data } \\
\text { coverage }\end{array}$ & $\begin{array}{l}\text { No, but it is FAO } \\
\text { Indicator I_1.4 }\end{array}$ & $\begin{array}{l}\text { Yes; very good data } \\
\text { availability and provides } \\
\text { an indication of a } \\
\text { healthy, varied diet }\end{array}$ \\
\hline 57 & $\begin{array}{l}\text { Food } \\
\text { (SDG 2) }\end{array}$ & $\begin{array}{l}\text { Prevalence of } \\
\text { obesity in the adult } \\
\text { population ( } 18 \text { years } \\
\text { and older) }\end{array}$ & $\begin{array}{l}\text { Prevalence of obesity in the adult population is the } \\
\text { percentage of adults ages } 18 \text { and over whose Body } \\
\text { Mass Index (BMI) is more than } 30 \mathrm{~kg} / \mathrm{m}^{2} \text {. Body Mass } \\
\text { Index (BMI) is a simple index of weight-for-height or } \\
\text { the weight in kilograms divided by the square of the } \\
\text { height in meters (FAO 2019-05-06). }\end{array}$ & $\begin{array}{l}\text { http://www.fao.org/economic/ess/ess- } \\
\text { fs/ess-fadata/en/\#.WDmBh9V96Uk } \\
\text { Source: World Health Organization } \\
\text { Global Health Observatory (GHO) } \\
\text { http://apps.who.int/gho/data/node.ma } \\
\text { in.A900A?lang=en }\end{array}$ & $\%$ & $\begin{array}{l}2016 \\
\text { Very good data } \\
\text { coverage. } \\
\text { Indicator utilised } \\
\text { in SDG Index for } \\
\text { SDG } 2\end{array}$ & $\begin{array}{l}\text { No, but it is FAO } \\
\text { Indicator I_ } 4.8\end{array}$ & $\begin{array}{l}\text { Yes; since it is utilised } \\
\text { within the SDG Index. } \\
\text { Although it has a } \\
\text { negative correlation with } \\
\text { the levels of } \\
\text { undernourishment, } \\
\text { stunting and wasting, it } \\
\text { measures a different } \\
\text { portion of the } \\
\text { population, i.e. adults } \\
>18 \text { years old vs children } \\
<5 \text { years old. It is viewed } \\
\text { as being a key indicator } \\
\text { of access to food despite } \\
\text { the negative correlation } \\
\text { with the other indicators } \\
\text { listed in the access to } \\
\text { food sub-index }\end{array}$ \\
\hline 58 & $\begin{array}{l}\text { Food } \\
\text { (SDG 2) }\end{array}$ & $\begin{array}{l}\text { Average dietary } \\
\text { energy supply } \\
\text { adequacy }^{8}\end{array}$ & $\begin{array}{l}\text { The indicator expresses the Dietary Energy Supply } \\
\text { (DES) as a percentage of the Average Dietary Energy } \\
\text { Requirement (ADER). Each country's or region's } \\
\text { average supply of calories for food consumption is } \\
\text { normalized by the average dietary energy requirement } \\
\text { estimated for its population to provide an index of } \\
\text { adequacy of the food supply in terms of calories (FAO } \\
\text { 2019-05-06). }\end{array}$ & $\begin{array}{l}\text { http://www.fao.org/economic/ess/ess- } \\
\text { fs/ess-fadata/en/\#.WDmBh9V96Uk } \\
\text { Source: FAOSTAT and ESS calculations }\end{array}$ & $\%$ & $\begin{array}{l}2015-2017 \\
\text { Very good data } \\
\text { coverage }\end{array}$ & $\begin{array}{l}\text { No, but it is FAO } \\
\text { Indicator I_1.1 }\end{array}$ & $\begin{array}{l}\text { Yes; less than } 10 \% \\
\text { missing data }\end{array}$ \\
\hline
\end{tabular}

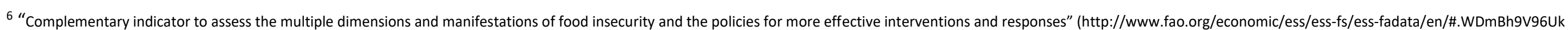
$-{ }^{*}$ not available in latest update of downloadable data)

7 "This indicator provides information on the quality of the diet" (http://www.fao.org/economic/ess/ess-fs/ess-fadata/en/\#.WDmBh9V96Uk)

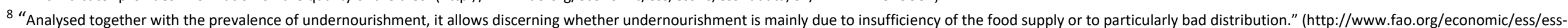
fs/ess-fadata/en/\#.WDmBh9V96Uk) 


\begin{tabular}{|c|c|c|c|c|c|c|c|c|}
\hline 59 & $\begin{array}{l}\text { Food } \\
\text { (SDG 2) }\end{array}$ & $\begin{array}{l}\text { Cereal import } \\
\text { dependency ratio }\end{array}$ & $\begin{array}{l}\text { The cereal imports dependency ratio tells how much of } \\
\text { the available domestic food supply of cereals has been } \\
\text { imported and how much comes from the country's } \\
\text { own production. It is computed as } \\
\text { (cereal imports - cereal exports)/(cereal production + } \\
\text { cereal imports - cereal exports) * } 100 \\
\text { Given this formula the indicator assumes only values } \\
<=100 \text {. Negative values indicate that the country is a } \\
\text { net exporter of cereals (FAO 2019-03-06). }\end{array}$ & $\begin{array}{l}\text { http://www.fao.org/economic/ess/ess- } \\
\text { fs/ess-fadata/en/\#.WDmBh9V96UkBU: } \\
\text { Source: FAOSTAT and ESS calculations }\end{array}$ & $\%$ & $\begin{array}{l}\text { 2011-2013 } \\
\text { Good data } \\
\text { coverage }\end{array}$ & $\begin{array}{l}\text { No, but it is FAO } \\
\text { indicator I_3.1 }\end{array}$ & $\begin{array}{l}\text { No; it is a good } \\
\text { indicator, but several } \\
\text { high-income countries } \\
\text { do not measure this } \\
\text { ratio since it is not } \\
\text { relevant to them (30.9\% } \\
\text { missing data for } 181 \\
\text { countries). This } \\
\text { indicator can be } \\
\text { truncated at zero in } \\
\text { order to exclude exports } \\
\text { from this indicator, since } \\
\text { the indicator is } \\
\text { essentially measuring } \\
\text { both imports and } \\
\text { exports. Imports are } \\
\text { important to this index } \\
\text { as they speak of the level } \\
\text { of self-sufficiency in food } \\
\text { production and security. } \\
\text { Yet this indicator has a } \\
\text { negative correlation with } \\
\text { the other indicators } \\
\text { within the "Access" sub- } \\
\text { pillar of the "Food"sub- } \\
\text { index, and is therefore } \\
\text { excluded. }\end{array}$ \\
\hline 60 & $\begin{array}{l}\text { Food } \\
\text { (SDG 2) }\end{array}$ & $\begin{array}{l}\text { Prevalence of } \\
\text { severe food } \\
\text { insecurity in the } \\
\text { total population }\end{array}$ & $\begin{array}{l}\text { The prevalence of severe food insecurity in an estimate } \\
\text { of the percentage of people in the population who live } \\
\text { in households classified as severely food insecure. } \\
\text { The assessment is conducted using data collected with } \\
\text { the Food Insecurity Experience Scale or a compatible } \\
\text { experience-based food security measurement } \\
\text { questionnaire (such as the HFSSM, the HFIAS, the EBIA, } \\
\text { the ELCSA, etc.). } \\
\text { The probability to be food insecure is estimated using } \\
\text { the one-parameter logistic Item Response Theory } \\
\text { model (the Rasch model) and thresholds for } \\
\text { classification are made cross country comparable by } \\
\text { calibrating the metrics obtained in each country } \\
\text { against the FIES global reference scale, maintained by } \\
\text { FAO. The threshold to classify "severe" food insecurity } \\
\text { corresponds to the severity associated with the item } \\
\text { "having not eaten for an entire day" on the global FIES } \\
\text { scale. } \\
\text { In simpler terms, a household is classified as severely } \\
\text { food insecure when at least one adult in the household } \\
\text { has reported to have been exposed, at times during }\end{array}$ & $\begin{array}{l}\text { http://www.fao.org/economic/ess/ess- } \\
\text { fs/ess-fadata/en/\#.WDmBh9V96Uk } \\
\text { Source: National surveys/Gallup World } \\
\text { Poll and ESS calculations }\end{array}$ & $\%$ & $\begin{array}{l}\text { 2015-2017 } \\
\text { Data missing for } \\
\text { many countries }\end{array}$ & $\begin{array}{l}\text { Yes, indicator } 2.1 .2 \\
\text { (CO20102) and FAO } \\
\text { indicator I_2.4 }\end{array}$ & $\begin{array}{l}\text { No; }>60 \% \text { of countries do } \\
\text { not have records for this } \\
\text { indicator. This is very } \\
\text { low. The JRC-COIN } \\
\text { guideline is that at an } \\
\text { indicator level } 65 \% \text { of } \\
\text { countries should have } \\
\text { valid data. On this basis, } \\
\text { this indicator is } \\
\text { unfortunately excluded. } \\
\text { It is unfortunate because } \\
\text { this is an official SDG } \\
\text { indicator. }\end{array}$ \\
\hline
\end{tabular}

9 “This is indicator 2.1.2 in the SDG framework, to monitor target 2.1 ("By 2030, end hunger and ensure access by all people, [...], to safe, nutritious and sufficient food all year round")." (http://www.fao.org/economic/ess/ess-fs//essfadata/en/\#.WDmBh9V96Uk) 


\begin{tabular}{|c|c|c|c|c|c|c|c|c|}
\hline & & & $\begin{array}{l}\text { the year, to several of the most severe experiences } \\
\text { described in the FIES questions, such as to have been } \\
\text { forced to reduce the quantity of the food, to have } \\
\text { skipped meals, having gone hungry, or having to go for } \\
\text { a whole day without eating because of a lack of money } \\
\text { or other resources. } \\
\text { It is an indicator of lack of food access (FAO 2019-03- } \\
\text { 06) }\end{array}$ & & & & & \\
\hline 61 & $\begin{array}{l}\text { Food } \\
\text { (SDG 2) }\end{array}$ & $\begin{array}{l}\text { Number of severely } \\
\text { food insecure } \\
\text { people }\end{array}$ & $\begin{array}{l}\text { Estimated number of people living in households } \\
\text { classified as severely food insecure. It is calculated by } \\
\text { multiplying the estimated percentage of people } \\
\text { affected by severe food insecurity (I_2.4) by the total } \\
\text { population. }\end{array}$ & $\begin{array}{l}\text { http://www.fao.org/economic/ess/ess- } \\
\text { fs/ess-fadata/en/\#.WDmBh9V96Uk } \\
\text { Source: ESS calculations }\end{array}$ & $\begin{array}{l}\text { Millions of } \\
\text { people }\end{array}$ & $\begin{array}{l}2015-2017 \\
\text { Poor data } \\
\text { coverage }\end{array}$ & No & $\begin{array}{l}\text { No, for same reason as } \\
\text { "Prevalence of severe } \\
\text { food insecurity in the } \\
\text { total population" }\end{array}$ \\
\hline 62 & $\begin{array}{l}\text { Food } \\
\text { (SDG 2) }\end{array}$ & $\begin{array}{l}\text { The share of food } \\
\text { expenditure of the } \\
\text { poor }^{10}\end{array}$ & $\begin{array}{l}\text { The proportion of food consumption over total } \\
\text { consumption (food and non-food) for the lowest } \\
\text { income quintile of the population. Due to the way in } \\
\text { which the share of food expenditures is defined in the } \\
\text { sources of data, this indicator captures the monetary } \\
\text { value of food obtained from all the possible food } \\
\text { sources (purchases, own-production, gift, in-kind } \\
\text { payment, etc.), rather than just the monetary value of } \\
\text { purchased food. Total consumption expenditures } \\
\text { include both food and non-food expenditures and } \\
\text { exclude non-consumption expenditures such as taxes, } \\
\text { insurances, etc. }\end{array}$ & $\begin{array}{l}\text { http://www.fao.org/economic/ess/ess- } \\
\text { fs/ess-fadata/en/\#.WDmBh9V96Uk } \\
\text { Source: ESS calculations }\end{array}$ & $\%$ & $\begin{array}{l}2014^{*} \\
\text { Very poor data } \\
\text { coverage }\end{array}$ & No & $\begin{array}{l}\text { No, very poor data } \\
\text { coverage, and this } \\
\text { indicator is not included } \\
\text { in latest list of FAO } \\
\text { indicators. }\end{array}$ \\
\hline 63 & $\begin{array}{l}\text { Food } \\
\text { (SDG 2) }\end{array}$ & Cereal yield & $\begin{array}{l}\text { Cereal yield, measured as kilograms per hectare of } \\
\text { harvested land, includes wheat, rice, maize, barley, } \\
\text { oats, rye, millet, sorghum, buckwheat, and mixed } \\
\text { grains. Production data on cereals relate to crops } \\
\text { harvested for dry grain only. Cereal crops harvested for } \\
\text { hay or harvested green for food, feed, or silage and } \\
\text { those used for grazing are excluded. The FAO allocates } \\
\text { production data to the calendar year in which the bulk } \\
\text { of the harvest took place. Most of a crop harvested } \\
\text { near the end of a year will be used in the following } \\
\text { year (World Bank 2019-03-06). }\end{array}$ & $\begin{array}{l}\text { https://data.worldbank.org/indicator/A } \\
\text { G.YLD.CREL.KG?view=chart } \\
\text { Source: World Bank }\end{array}$ & $\begin{array}{l}\text { kg per } \\
\text { hectare }\end{array}$ & $\begin{array}{l}2016 \\
\text { Very good data } \\
\text { coverage. } \\
\text { Indicator utilised } \\
\text { in SDG Index for } \\
\text { SDG } 2\end{array}$ & No & $\begin{array}{l}\text { Yes; good data } \\
\text { availability and the } \\
\text { indicator is relevant to } \\
\text { food security }\end{array}$ \\
\hline 64 & $\begin{array}{l}\text { Food } \\
\text { (SDG 2) }\end{array}$ & $\begin{array}{l}\text { Volume of } \\
\text { production per } \\
\text { labour unit by } \\
\text { classes of } \\
\text { farming/pastoral/fo } \\
\text { restry enterprise } \\
\text { size }\end{array}$ & $\begin{array}{l}\text { Volume of agricultural production of small-scale food } \\
\text { producer in crop, livestock, fisheries, and forestry } \\
\text { activities per number of days (UN Stats, 2018) }\end{array}$ & Not available & $\begin{array}{l}\text { Volume/ } \\
\text { production } \\
\text { unit }\end{array}$ & None & Yes; indicator 2.3.1 & $\begin{array}{l}\text { No; there is no usable } \\
\text { data available yet }\end{array}$ \\
\hline 65 & $\begin{array}{l}\text { Food } \\
\text { (SDG 2) }\end{array}$ & $\begin{array}{l}\text { Average income of } \\
\text { small-scale food } \\
\text { producers, by sex }\end{array}$ & $\begin{array}{l}\text { measures income from on-farm production activities, } \\
\text { which is related to the production of food and } \\
\text { agricultural products. This includes income from crop }\end{array}$ & Not available & $\begin{array}{l}\text { Annual } \\
\text { income }\end{array}$ & $\begin{array}{l}\text { None; data is still } \\
\text { not available in a } \\
\text { systematic and }\end{array}$ & Yes; indicator 2.3.2 & $\begin{array}{l}\text { No; there is no usable } \\
\text { data available yet }\end{array}$ \\
\hline
\end{tabular}

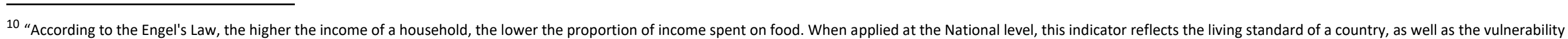

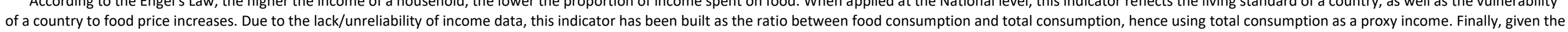

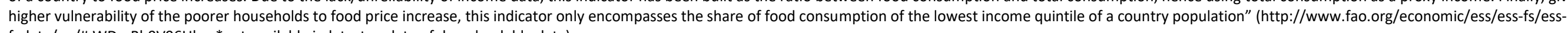
fadata/en/\#.WDmBh9V96Uk - * not available in latest update of downloadable data) 


\begin{tabular}{|c|c|c|c|c|c|c|c|c|}
\hline & & $\begin{array}{l}\text { and indigenous } \\
\text { status }\end{array}$ & $\begin{array}{l}\text { production, livestock production, fisheries and } \\
\text { aquaculture production, and from forestry production. } \\
\text { The indicator is computed as annual income (UN Stats, } \\
\text { 2018) }\end{array}$ & & & $\begin{array}{l}\text { harmonized } \\
\text { fashion }\end{array}$ & & \\
\hline 66 & $\begin{array}{l}\text { Food } \\
\text { (SDG 2) }\end{array}$ & $\begin{array}{l}\text { Proportion of } \\
\text { agricultural area } \\
\text { under productive } \\
\text { and sustainable } \\
\text { agriculture } \\
\end{array}$ & $\begin{array}{l}\text { measure both the extent of land under productive and } \\
\text { sustainable agriculture, as well as the extent of land } \\
\text { area under agriculture. Focuses on agricultural land, } \\
\text { and therefore primarily on land that is used to grow } \\
\text { crops and raise livestock (UN Stats, 2018) }\end{array}$ & Not available & Percentage & None & Yes; indicator 2.4.1 & $\begin{array}{l}\text { No, no data readily } \\
\text { available }\end{array}$ \\
\hline 67 & $\begin{array}{l}\text { Food } \\
\text { (SDG 2) }\end{array}$ & $\begin{array}{l}\text { Number of plant } \\
\text { and animal genetic } \\
\text { resources for food } \\
\text { and agriculture } \\
\text { secured in either } \\
\text { medium or long- } \\
\text { term conservation } \\
\text { facilities }\end{array}$ & $\begin{array}{l}\text { The conservation of plant and animal genetic resources } \\
\text { for food and agriculture (GRFA) in medium or long } \\
\text { term conservation facilities (ex situ in genebanks) } \\
\text { represents the most trusted means of conserving } \\
\text { genetic resources worldwide. Plant and animal GRFA } \\
\text { conserved in these facilities can be easily used in } \\
\text { breeding programmes as well, even directly on-farm } \\
\text { (UN Stats, 2018) }\end{array}$ & $\begin{array}{l}\text { Not available yet, although data } \\
\text { compilers have been appointed per } \\
\text { country. } \\
\text { http://www.fao.org/dad-is/sdg-251/en/ }\end{array}$ & $\begin{array}{l}\text { No. of } \\
\text { species }\end{array}$ & None & Yes; indicator 2.5.1 & $\begin{array}{l}\text { No; there is no usable } \\
\text { data available yet }\end{array}$ \\
\hline 68 & $\begin{array}{l}\text { Food } \\
\text { (SDG 2) }\end{array}$ & $\begin{array}{l}\text { Proportion of local } \\
\text { breeds classified as } \\
\text { being at risk, not-at- } \\
\text { risk or at unknown } \\
\text { level of risk of } \\
\text { extinction } \\
\end{array}$ & $\begin{array}{l}\text { The indicator presents the percentage of livestock } \\
\text { breeds classified as being at risk, not at risk or of } \\
\text { unknown risk of extinctions at a certain moment in } \\
\text { time, as well as the trends for those percentages (UN } \\
\text { Stats, 2018) }\end{array}$ & $\begin{array}{l}\text { http://www.fao.org/dad- } \\
\text { is/dataexport/en/ } \\
\text { Source: FAO }\end{array}$ & Percentage & $\begin{array}{l}\text { Data collection } \\
\text { dates are not } \\
\text { specified. Data is } \\
\text { available for } \\
\text { various species } \\
\text { per country. }\end{array}$ & Yes; indicator 2.5.2 & $\begin{array}{l}\text { No; although data is } \\
\text { available per country, it } \\
\text { seems like the data was } \\
\text { only collected once as no } \\
\text { sampling dates are } \\
\text { specified }\end{array}$ \\
\hline 69 & $\begin{array}{l}\text { Food } \\
\text { (SDG 2) }\end{array}$ & $\begin{array}{l}\text { The agriculture } \\
\text { orientation index } \\
\text { for government } \\
\text { expenditures }\end{array}$ & $\begin{array}{l}\text { The Agriculture Orientation Index (AOI) for } \\
\text { Government Expenditures is defined as the Agriculture } \\
\text { Share of Government Expenditures, divided by the } \\
\text { Agriculture Share of GDP, where Agriculture refers to } \\
\text { the agriculture, forestry, fishing and hunting sector. } \\
\text { The measure in a currency-free index, calculated as the } \\
\text { ratio of these two shares. National governments are } \\
\text { requested to compile Government Expenditures } \\
\text { according to the international Classification of } \\
\text { Functions of Government (COFOC), and Agriculture } \\
\text { Share of GDP according to the System of National } \\
\text { Accounts (SNA) (UN Stats, 2018) }\end{array}$ & $\begin{array}{l}\text { http://www.fao.org/faostat/en/\#data/l } \\
\text { G/visualize } \\
\text { Source: FAOSTAT }\end{array}$ & Percentage & $\begin{array}{l}\text { Data can be } \\
\text { calculated using } \\
\text { government } \\
\text { expenditure and } \\
\text { GDP, but data } \\
\text { specific for this } \\
\text { indicator is not } \\
\text { available. }\end{array}$ & Yes; indicator 2. a.1 & $\begin{array}{l}\text { No; although there is } \\
\text { data per country } \\
\text { available, it is } \\
\text { fragmented. Further, it is } \\
\text { not best practice to } \\
\text { incorporate an index as } \\
\text { part of another index. }\end{array}$ \\
\hline 70 & $\begin{array}{l}\text { Food } \\
\text { (SDG 2) }\end{array}$ & $\begin{array}{l}\text { Total official flows } \\
\text { (official } \\
\text { development } \\
\text { assistance plus } \\
\text { other official flows) } \\
\text { to the agriculture } \\
\text { sector }\end{array}$ & $\begin{array}{l}\text { Gross disbursements of total ODA and other official } \\
\text { flows from all donors to the agriculture sector (UN } \\
\text { Stats, 2018) }\end{array}$ & $\begin{array}{l}\text { Food aid: https://www.oecd- } \\
\text { ilibrary.org/development/data/oecd- } \\
\text { international-development- } \\
\text { statistics/official-and-private- } \\
\text { flows_data-00072-en }\end{array}$ & Million USD & $\begin{array}{l}\text { Data is available } \\
\text { from } 1995-2017 \\
\text { for } 35 \text { countries } \\
\text { with data missing } \\
\text { for some years. }\end{array}$ & Yes; indicator 2. a.2 & $\begin{array}{l}\text { No; data is only available } \\
\text { for } 35 \text { countries. The } \\
\text { JRC-COIN guideline is } \\
\text { that at an indicator level } \\
65 \% \text { of countries should } \\
\text { have valid data. }\end{array}$ \\
\hline 71 & $\begin{array}{l}\text { Food } \\
\text { (SDG 2) }\end{array}$ & $\begin{array}{l}\text { Agricultural export } \\
\text { subsidies }\end{array}$ & $\begin{array}{l}\text { Agricultural export subsidies are defined as export } \\
\text { subsidies budgetary outlays and quantities as notified } \\
\text { by WTO Members in Tables ES:1 and supporting Tables } \\
\text { ES:2 (following templates in document G/AG/2 dated } \\
30 \text { June 1995) (UN Stats, 2018) }\end{array}$ & $\begin{array}{l}\text { https://www.wto.org/english/tratop e/ } \\
\text { agric e/transparency toolkit e.htm } \\
\text { Source: World Trade Organization }\end{array}$ & Million USD & $\begin{array}{l}\text { Data is available } \\
\text { from } 1995-2014 \\
\text { for } 24 \text { countries. }\end{array}$ & Yes; indicator 2. b.1 & $\begin{array}{l}\text { No; although it is } \\
\text { important to consider } \\
\text { financial flows of food } \\
\text { export, this level of } \\
\text { detail is not yet required } \\
\text { in this WEF nexus } \\
\text { framework }\end{array}$ \\
\hline
\end{tabular}




\begin{tabular}{|c|c|c|c|c|c|c|c|c|}
\hline 72 & $\begin{array}{l}\text { Food } \\
\text { (SDG 2) }\end{array}$ & $\begin{array}{l}\text { Indicator of food } \\
\text { price anomalies }\end{array}$ & $\begin{array}{l}\text { The indicator of food price anomalies (IFPA) identifies } \\
\text { markets prices that are abnormally high. The IFPA } \\
\text { relies on a weighted compound growth rate that } \\
\text { accounts for both within year and across year price } \\
\text { growth. The indicator directly evaluates growth in } \\
\text { prices over a particular month over many years, taking } \\
\text { into account seasonality in agricultural markets and } \\
\text { inflation, allowing to answer the question of whether } \\
\text { or not a change in price is abnormal for any particular } \\
\text { period (UN Stats, 2018) }\end{array}$ & $\begin{array}{l}\text { http://www.fao.org/giews/food- } \\
\text { prices/tool/public/\#/dataset/internation } \\
\text { al }\end{array}$ & - & $\begin{array}{l}\text { Data available for } \\
2016 \text { for } 57 \\
\text { countries } \\
\text { (specifically for } \\
\text { rice; data also } \\
\text { available for } \\
\text { wheat, sorghum, } \\
\text { maize, and millet) }\end{array}$ & Yes; indicator 2. c.1 & $\begin{array}{l}\text { No; data is difficult to } \\
\text { manage as it does not } \\
\text { download to an excel } \\
\text { format. Further, it is not } \\
\text { best practice to } \\
\text { incorporate an index as } \\
\text { part of another index. }\end{array}$ \\
\hline 73 & $\begin{array}{l}\text { Food } \\
\text { (SDG 2) }\end{array}$ & $\begin{array}{l}\text { Global food loss } \\
\text { index }\end{array}$ & $\begin{array}{l}\text { No data for this indicator is currently available and its } \\
\text { methodology is still under development (UN Stats, } \\
\text { 2018) }\end{array}$ & Not available yet & - & None & Yes; indicator 12.3.1 & $\begin{array}{l}\text { No; although this } \\
\text { indicator is an SDG } \\
\text { indicator it is not best } \\
\text { practice to incorporate } \\
\text { an index as part of } \\
\text { another index. }\end{array}$ \\
\hline 74 & $\begin{array}{l}\text { Food } \\
\text { (SDG 2) }\end{array}$ & $\begin{array}{l}\text { Average value of } \\
\text { food production }\end{array}$ & $\begin{array}{l}\text { The indicator expresses the food net production value } \\
\text { (in constant 2004-06 international dollars), as } \\
\text { estimated by FAO and published by FAOSTAT, in per } \\
\text { capita terms (FAO 2019-03-06) }\end{array}$ & $\begin{array}{l}\text { http://www.fao.org/economic/ess/ess- } \\
\text { fs/ess-fadata/en/\#.Xlix_8t7lhG }\end{array}$ & I\$ per caput & $\begin{array}{l}\text { Data available } \\
\text { from } 1999-2014 \\
\text { for } 201 \text { countries. }\end{array}$ & $\begin{array}{l}\text { No, but it is FAO } \\
\text { indicator I_1.2 }\end{array}$ & $\begin{array}{l}\text { Yes; very good data } \\
\text { coverage that includes } \\
\text { data from } 201 \text { countries. } \\
\text { The data can be used to } \\
\text { infer priorities in terms } \\
\text { of resource allocation in } \\
\text { the WEF nexus. }\end{array}$ \\
\hline 75 & $\begin{array}{l}\text { Food } \\
\text { (SDG 2) }\end{array}$ & $\begin{array}{l}\text { Value of food } \\
\text { imports over total } \\
\text { merchandise } \\
\text { exports }\end{array}$ & $\begin{array}{l}\text { Value of food (excl. fish) imports over total } \\
\text { merchandise exports (FAO 2019-03-06) }\end{array}$ & $\begin{array}{l}\text { http://www.fao.org/economic/ess/ess- } \\
\text { fs/ess-fadata/en/\#.Xlix_8t7lhG }\end{array}$ & Percentage & $\begin{array}{l}\text { Data available } \\
\text { from } 1999-2011 \\
\text { for } 193 \text { countries }\end{array}$ & $\begin{array}{l}\text { No, but it is FAO } \\
\text { indicator I_3.3 }\end{array}$ & $\begin{array}{l}\text { No, very good data } \\
\text { coverage that includes } \\
\text { data from } 193 \text { countries. } \\
\text { However, there is a low } \\
\text { correlation }(<0.4) \text { with } \\
\text { other key indicators } \\
\text { relating to food } \\
\text { availability. }\end{array}$ \\
\hline 76 & $\begin{array}{l}\text { Food } \\
\text { (SDG 2) }\end{array}$ & $\begin{array}{l}\text { Agricultural } \\
\text { machinery }\end{array}$ & $\begin{array}{l}\text { Agricultural machinery refers to the number of wheel } \\
\text { and crawler tractors (excluding garden tractors) in use } \\
\text { in agriculture at the end of the calendar year specified } \\
\text { or during the first quarter of the following year. Arable } \\
\text { land includes land defined by the FAO as land under } \\
\text { temporary crops (double-cropped areas are counted } \\
\text { once), temporary meadows for mowing or for pasture, } \\
\text { land under market or kitchen gardens, and land } \\
\text { temporarily fallow. Land abandoned as a result of } \\
\text { shifting cultivation is excluded (FAO: } 2019-04-29 \text { ) }\end{array}$ & $\begin{array}{l}\text { https://data.worldbank.org/indicator/A } \\
\text { G.LND.TRAC.ZS?view=chart } \\
\text { Source: Food and Agriculture } \\
\text { Organization, electronic files and web } \\
\text { site }\end{array}$ & $\begin{array}{l}\text { Tractors/ } \\
100 \mathrm{~km}^{2} \text { of } \\
\text { arable land }\end{array}$ & $\begin{array}{l}\text { Data available } \\
\text { from 1961-2009; } \\
\text { for only } 8 \\
\text { countries in } 2009 \\
\text { but for } \\
\text { approximately } \\
164 \text { countries in } \\
1965\end{array}$ & No & $\begin{array}{l}\text { No, this indicator was } \\
\text { measured widely up } \\
\text { until } 2000 \text {, and to some } \\
\text { degree until } 2008, \text { but is } \\
\text { no longer recorded. }\end{array}$ \\
\hline 77 & $\begin{array}{l}\text { Food } \\
\text { (SDG 2) }\end{array}$ & $\begin{array}{l}\text { Percent of arable } \\
\text { land equipped for } \\
\text { irrigation }\end{array}$ & $\begin{array}{l}\text { Ratio between arable land equipped for irrigation and } \\
\text { total arable land. } \\
\text { Arable land is defined as the land under temporary } \\
\text { agricultural crops (multiple-cropped areas are counted } \\
\text { only once), temporary meadows for mowing or } \\
\text { pasture, land under market and kitchen gardens and } \\
\text { land temporarily fallow (less than five years). The } \\
\text { abandoned land resulting from shifting cultivation is } \\
\text { not included in this category. Data for arable land are }\end{array}$ & $\begin{array}{l}\text { http://www.fao.org/economic/ess/ess- } \\
\text { fs/ess-fadata/en/\#.Xlix 8t7lhG } \\
\text { Source: FAOSTAT and ESS calculations } \\
\text { (11 Sep 2018) }\end{array}$ & $\%$ & $\begin{array}{l}\text { Data available } \\
\text { from } 1999 \text { to- } \\
2015 \text { for } 178 \\
\text { countries with } \\
\text { missing data for } \\
\text { some years. }\end{array}$ & $\begin{array}{l}\text { No, but it is FAO } \\
\text { indicator I_3.2 }\end{array}$ & $\begin{array}{l}\text { No, irrigation is a major } \\
\text { user of water worldwide, } \\
\text { and a key component of } \\
\text { the WEF nexus, despite } \\
\text { it having a poor } \\
\text { correlation with some of } \\
\text { the other indicators in } \\
\text { food availability. This } \\
\text { indicator has a negative } \\
\text { correlation with the } \\
\text { other indicators within }\end{array}$ \\
\hline
\end{tabular}




\begin{tabular}{|c|c|c|c|c|c|c|c|c|}
\hline & & & $\begin{array}{l}\text { not meant to indicate the amount of land that is } \\
\text { potentially cultivable. } \\
\text { Total arable land equipped for irrigation is defined as } \\
\text { the area equipped to provide water (via irrigation) to } \\
\text { the crops. It includes areas equipped for full and partial } \\
\text { control irrigation, equipped lowland areas, pastures, } \\
\text { and areas equipped for spate irrigation (FAO: 2019-04- } \\
\text { 29). }\end{array}$ & & & & & $\begin{array}{l}\text { the "Access" sub-pillar of } \\
\text { the "Food"sub-index, } \\
\text { and is therefore } \\
\text { excluded. }\end{array}$ \\
\hline 78 & $\begin{array}{l}\text { Food } \\
\text { (SDG 2) }\end{array}$ & $\begin{array}{l}\text { Agriculture, forestry } \\
\text { and fishery, value } \\
\text { added }\end{array}$ & $\begin{array}{l}\text { Agriculture corresponds to ISIC divisions } 1-5 \text { and } \\
\text { includes forestry, hunting, and fishing, as well as } \\
\text { cultivation of crops and livestock production. Value } \\
\text { added is the net output of a sector after adding up all } \\
\text { outputs and subtracting intermediate inputs. It is } \\
\text { calculated without making deductions for depreciation } \\
\text { of fabricated assets or depletion and degradation of } \\
\text { natural resources. The origin of value added is } \\
\text { determined by the International Standard Industrial } \\
\text { Classification (ISIC), revision } 3 \text {. Note: This value is not } \\
\text { specific to crop production, so care should be taken to } \\
\text { ensure proper implementation.(FAO 2019-05-25) }\end{array}$ & $\begin{array}{l}\text { https://data.worldbank.org/indicator/N } \\
\text { V.AGR.TOTL.ZS } \\
\text { Source: Food and Agriculture } \\
\text { Organization, AQUASTAT data }\end{array}$ & $\%$ of GDP & $\begin{array}{l}\text { Data available } \\
\text { from } 1966-2017 \\
\text { with many missing } \\
\text { data per year. } \\
\text { Most recent data } \\
\text { are available for } \\
2012 \text { for } 171 \\
\text { countries. }\end{array}$ & No & $\begin{array}{l}\text { No, very good data } \\
\text { availability and very } \\
\text { relevant indicator } \\
\text { regarding the value of } \\
\text { land and water-based } \\
\text { products/food to the } \\
\text { economy, but low } \\
\text { correlation with most } \\
\text { indicators contributing } \\
\text { to food availability }\end{array}$ \\
\hline 79 & $\begin{array}{l}\text { Food } \\
\text { (SDG 2) }\end{array}$ & $\begin{array}{l}\text { Electricity capacity } \\
\text { in MW for } \\
\text { renewable } \\
\text { municipal waste }\end{array}$ & ??? & $\begin{array}{l}\text { https://www.irena.org/Statistics/View- } \\
\text { Data-by-Topic/Capacity-and- } \\
\text { Generation/Technologies } \\
\text { Source: Source: IRENA (2019), } \\
\text { Renewable capacity statistics 2019; and } \\
\text { IRENA (2018), Renewable Energy } \\
\text { Statistics 2018, The International } \\
\text { Renewable Energy Agency, Abu Dhabi. }\end{array}$ & MW & $\begin{array}{l}\text { Data available } \\
\text { from 2000-2018 } \\
\text { with many missing } \\
\text { data per country. } \\
\text { Most recent data } \\
\text { are available for } \\
2018 \text { for } 41 \\
\text { countries. }\end{array}$ & No & $\begin{array}{l}\text { No; data is only available } \\
\text { for } 41 \text { countries. The } \\
\text { JRC-COIN guideline is } \\
\text { that at an indicator level } \\
65 \% \text { of countries should } \\
\text { have valid data. }\end{array}$ \\
\hline 80 & $\begin{array}{l}\text { Food } \\
\text { (SDG 2) }\end{array}$ & $\begin{array}{l}\text { Electricity } \\
\text { generation in GWh } \\
\text { for renewable } \\
\text { municipal waste }\end{array}$ & ??? & $\begin{array}{l}\text { https://www.irena.org/Statistics/View- } \\
\text { Data-by-Topic/Capacity-and- } \\
\text { Generation/Technologies } \\
\text { Source: Source: IRENA (2019), } \\
\text { Renewable capacity statistics 2019; and } \\
\text { IRENA (2018), Renewable Energy } \\
\text { Statistics 2018, The International } \\
\text { Renewable Energy Agency, Abu Dhabi. }\end{array}$ & GWh & $\begin{array}{l}\text { Data available } \\
\text { from } 2000-2016 \\
\text { with many missing } \\
\text { data per country. } \\
\text { Most recent data } \\
\text { are available for } \\
2016 \text { for } 37 \\
\text { countries. }\end{array}$ & No & $\begin{array}{l}\text { No; data is only available } \\
\text { for } 37 \text { countries. The } \\
\text { JRC-COIN guideline is } \\
\text { that at an indicator level } \\
65 \% \text { of countries should } \\
\text { have valid data. }\end{array}$ \\
\hline 81 & $\begin{array}{l}\text { Food } \\
\text { (SDG 2) }\end{array}$ & $\begin{array}{l}\text { Electricity capacity } \\
\text { in MW for solid } \\
\text { biofuel }\end{array}$ & & $\begin{array}{l}\text { https://www.irena.org/Statistics/View- } \\
\text { Data-by-Topic/Capacity-and- } \\
\text { Generation/Technologies } \\
\text { Source: Source: IRENA (2019), } \\
\text { Renewable capacity statistics 2019; and } \\
\text { IRENA (2018), Renewable Energy } \\
\text { Statistics 2018, The International } \\
\text { Renewable Energy Agency, Abu Dhabi. }\end{array}$ & MW & $\begin{array}{l}\text { Data available } \\
\text { from } 2000-2018 \\
\text { with many missing } \\
\text { data per country. } \\
\text { Most recent data } \\
\text { are available for } \\
2018 \text { for } 108 \\
\text { countries. }\end{array}$ & No & $\begin{array}{l}\text { No, this data is included } \\
\text { in the renewable energy } \\
\text { consumption and output } \\
\text { indicators }\end{array}$ \\
\hline 82 & $\begin{array}{l}\text { Food } \\
\text { (SDG 2) }\end{array}$ & $\begin{array}{l}\text { Electricity } \\
\text { generation in GWh } \\
\text { for solid biofuel }\end{array}$ & & $\begin{array}{l}\text { https://www.irena.org/Statistics/View- } \\
\text { Data-by-Topic/Capacity-and- } \\
\text { Generation/Technologies } \\
\text { Source: Source: IRENA (2019), } \\
\text { Renewable capacity statistics 2019; and } \\
\text { IRENA (2018), Renewable Energy }\end{array}$ & GWh & $\begin{array}{l}\text { Data available } \\
\text { from } 2000-2016 \\
\text { with many missing } \\
\text { data per country. } \\
\text { Most recent data } \\
\text { are available for } \\
\end{array}$ & No & $\begin{array}{l}\text { No, this data is included } \\
\text { in the renewable energy } \\
\text { consumption and output } \\
\text { indicators }\end{array}$ \\
\hline
\end{tabular}




\begin{tabular}{|c|c|c|c|c|c|c|c|c|}
\hline & & & & $\begin{array}{l}\text { Statistics 2018, The International } \\
\text { Renewable Energy Agency, Abu Dhabi. }\end{array}$ & & $\begin{array}{l}2016 \text { for } 103 \\
\text { countries. }\end{array}$ & & \\
\hline 83 & $\begin{array}{l}\text { Food } \\
\text { (SDG 2) }\end{array}$ & $\begin{array}{l}\text { Electricity capacity } \\
\text { in MW for liquid } \\
\text { biofuel }\end{array}$ & & $\begin{array}{l}\text { https://www.irena.org/Statistics/View- } \\
\text { Data-by-Topic/Capacity-and- } \\
\text { Generation/Technologies }\end{array}$ & MW & $\begin{array}{l}\text { Data available } \\
\text { from 2000-2018 } \\
\text { with many missing } \\
\text { data per country. } \\
\text { Most recent data } \\
\text { are available for } \\
2018 \text { for } 14 \\
\text { countries. }\end{array}$ & No & $\begin{array}{l}\text { No; data is only available } \\
\text { for } 14 \text { countries. The } \\
\text { JRC-COIN guideline is } \\
\text { that at an indicator level } \\
65 \% \text { of countries should } \\
\text { have valid data. }\end{array}$ \\
\hline 84 & $\begin{array}{l}\text { Food } \\
\text { (SDG 2) }\end{array}$ & $\begin{array}{l}\text { Electricity } \\
\text { generation in GWh } \\
\text { for liquid biofuel }\end{array}$ & & $\begin{array}{l}\text { Source: Source: IRENA (2019), } \\
\text { Renewable capacity statistics 2019; and } \\
\text { IRENA (2018), Renewable Energy } \\
\text { Statistics 2018, The International } \\
\text { Renewable Energy Agency, Abu Dhabi. }\end{array}$ & GWh & $\begin{array}{l}\text { Data available } \\
\text { from 2000-2016 } \\
\text { with many missing } \\
\text { data per country. } \\
\text { Most recent data } \\
\text { are available for } \\
2016 \text { for } 17 \\
\text { countries. }\end{array}$ & No & $\begin{array}{l}\text { No; data is only available } \\
\text { for } 17 \text { countries. The } \\
\text { JRC-COIN guideline is } \\
\text { that at an indicator level } \\
65 \% \text { of countries should } \\
\text { have valid data. }\end{array}$ \\
\hline 85 & $\begin{array}{l}\text { Food } \\
\text { (SDG 2) }\end{array}$ & $\begin{array}{l}\text { Alien invasive } \\
\text { species }\end{array}$ & $\begin{array}{l}\text { Area of agricultural land that has been encroached by } \\
\text { alien invasive species, resulting is less arable land for } \\
\text { food production and an increase in water consumption }\end{array}$ & Not available & $\mathrm{Ha} /$ year & None & No & $\begin{array}{l}\text { No; there is no usable } \\
\text { data available yet } \\
\text { however it is important } \\
\text { to consider alien invasive } \\
\text { plant species as they } \\
\text { affect food and water } \\
\text { security }\end{array}$ \\
\hline 86 & $\begin{array}{l}\text { Food } \\
\text { (SDG 2) }\end{array}$ & $\begin{array}{l}\text { Proportion of } \\
\text { countries adopting } \\
\text { relevant national } \\
\text { legislation and } \\
\text { adequately } \\
\text { resourcing the } \\
\text { prevention or } \\
\text { control of invasive } \\
\text { alien species }\end{array}$ & $\begin{array}{l}\text { Commitment by countries to relevant multinational } \\
\text { agreements, specifically: (1) National adoption of } \\
\text { invasive alien species-relevant international policy. (2) } \\
\text { Percentage of countries with (a) national strategies for } \\
\text { preventing and controlling invasive alien species; and } \\
\text { (b) national legislation and policy relevant to invasive } \\
\text { alien species. The translation of policy arrangements } \\
\text { into action by countries to implement policy and } \\
\text { actively prevent and control invasive alien species IAS } \\
\text { and the resourcing of this action, specifically: (3) } \\
\text { National allocation of resources towards the } \\
\text { prevention or control of invasive alien species. (UN } \\
\text { Stats, 2018) }\end{array}$ & Not available & $\%$ & None & Yes; indicator 15.8 .1 & $\begin{array}{l}\text { No; there is no usable } \\
\text { data available yet }\end{array}$ \\
\hline 87 & $\begin{array}{l}\text { Food } \\
\text { (SDG 2) }\end{array}$ & $\begin{array}{l}\text { Pests destroying } \\
\text { crops } \\
2\end{array}$ & $\begin{array}{l}\text { Hectares of crops that are lost per year due to the } \\
\text { invasion of pest species (armyworm, corn root worm } \\
\text { etc) and diseases caused by fungi and bacteria (potato } \\
\text { blight, coffee leaf rust etc) }\end{array}$ & Not available & $\begin{array}{l}\text { Ha/year } \\
\text { or kg/ha }\end{array}$ & None & No & $\begin{array}{l}\text { No; there is no usable } \\
\text { data available yet } \\
\text { however it is important } \\
\text { to consider pests as they } \\
\text { are seen as the greatest } \\
\text { threat to food security, } \\
\text { and indirectly affects } \\
\text { water security. }\end{array}$ \\
\hline
\end{tabular}


Addendum B: Untreated Indicator Data

\begin{tabular}{|c|c|c|c|c|c|c|c|c|c|c|c|c|c|c|c|c|c|c|c|c|c|c|}
\hline \multirow[b]{2}{*}{ Country } & & ind.01 & ind.02 & ind.03 & ind.04 & ind.05 & ind.06 & ind.07 & ind.08 & ind.09 & ind.10 & ind.11 & ind.12 & ind.13 & ind.14 & ind.15 & ind.16 & ind.17 & ind.18 & ind.19 & ind.20 & ind.21 \\
\hline & & 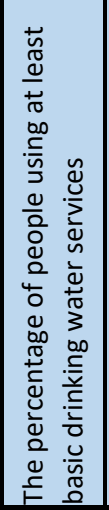 & 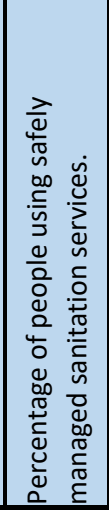 & 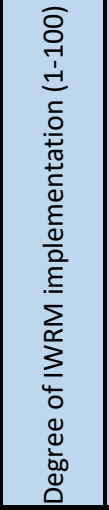 & 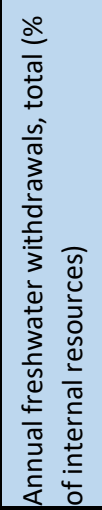 & 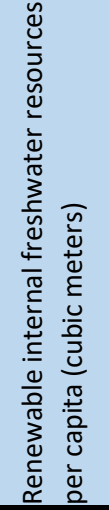 & 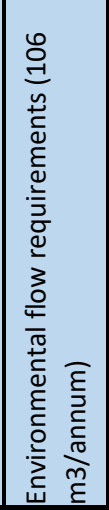 & 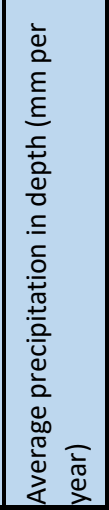 & 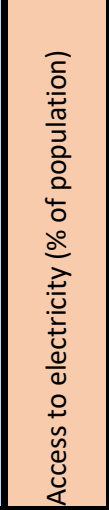 & 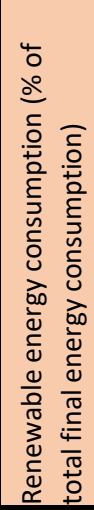 & 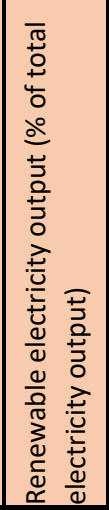 & 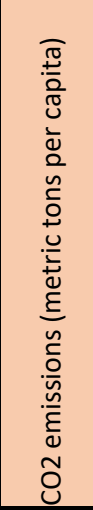 & 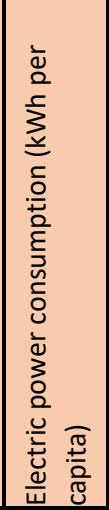 & 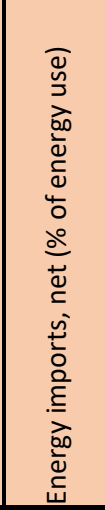 & 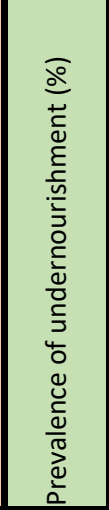 & 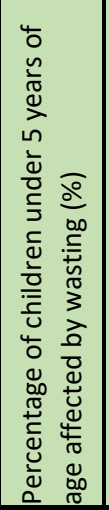 & 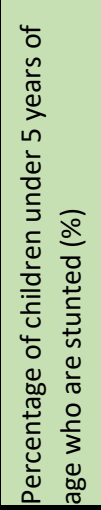 & 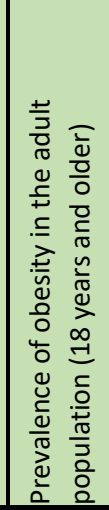 & 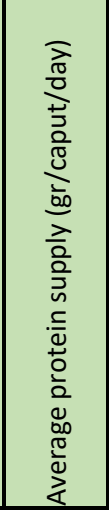 & 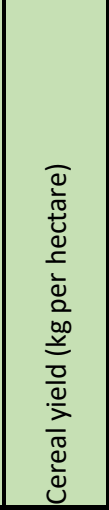 & 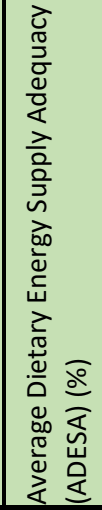 & 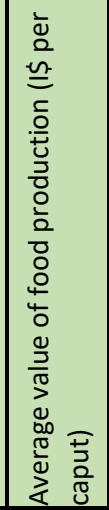 \\
\hline Afghanistan & AFG & 63.0 & 39.2 & 11.5 & 43.0 & 1439 & 28.3 & 327.0 & 84.1 & 18.4 & 86.1 & 0.3 & $n / a$ & $n / a$ & 30.3 & 9.5 & 40.9 & 4.5 & 33.0 & 1981.7 & 95.0 & 104.0 \\
\hline Albania & ALB & 91.4 & 97.7 & 43.1 & 4.9 & 9311 & 13.6 & 1485.0 & 100.0 & 38.6 & 100.0 & 2.0 & 2309 & 13.8 & 5.5 & 9.4 & 23.1 & 22.3 & 104.0 & 4716.4 & 129.0 & 462.0 \\
\hline Algeria & DZA & 93.5 & 87.5 & 48.2 & 69.4 & 288 & 4.6 & 89.0 & 99.4 & 0.1 & 0.3 & 3.7 & 1356 & -177.1 & 4.7 & 4.1 & 11.7 & 26.6 & 75.0 & 1560.7 & 143.0 & 220.0 \\
\hline Angola & AGO & 41.0 & 39.4 & 37.1 & 0.5 & 5498 & 110.7 & \begin{tabular}{|l|l}
1010.0 \\
\end{tabular} & 40.5 & 49.6 & 53.2 & 1.3 & 312 & -541.0 & 23.9 & 4.9 & 37.6 & 6.8 & 52.0 & 934.7 & 108.0 & 137.0 \\
\hline Argentina & ARG & 99.6 & 94.8 & 38.2 & 12.9 & 6794 & 515.8 & \begin{tabular}{|l|}
591.0 \\
\end{tabular} & 100.0 & 10.0 & 28.1 & 4.7 & 3052 & 13.0 & 3.8 & 1.2 & 8.2 & 28.5 & 114.0 & 5096.5 & 135.0 & 1030.0 \\
\hline Armenia & ARM & 98.9 & 91.6 & 35.9 & 42.9 & 2360 & 2.8 & 562.0 & 100.0 & 15.8 & 28.3 & 1.9 & 1966 & 71.3 & 4.3 & 4.2 & 9.4 & 20.9 & 91.0 & 3076.1 & 120.0 & 426.0 \\
\hline Australia & AUS & 100.0 & 100.0 & 85.5 & 3.1 & 20932 & 243.3 & \begin{tabular}{|l|}
534.0 \\
\end{tabular} & 100.0 & 9.2 & 13.6 & 15.4 & 10059 & $\mid-190.2$ & 1.2 & 0.8 & 2.0 & 30.4 & 150.0 & 2074.3 & 132.0 & 1009.0 \\
\hline Austria & AUT & 100.0 & 100.0 & 91.1 & 6.3 & 6435 & 41.5 & 1110.0 & \begin{tabular}{|l}
100.0 \\
\end{tabular} & 34.4 & 76.5 & 6.9 & 8356 & 63.5 & 1.2 & 0.8 & 2.6 & 21.9 & 168.0 & 7245.2 & \begin{tabular}{|l|l}
148.0 \\
\end{tabular} & 472.0 \\
\hline Azerbaijan & AZE & 84.4 & 89.3 & 66.0 & 147.5 & 851 & 12.0 & 447.0 & 100.0 & 2.3 & 7.0 & 3.9 & 2202 & -310.4 & 1.2 & 3.1 & 18.0 & 19.9 & 58.0 & 3004.7 & 130.0 & 266.0 \\
\hline Bangladesh & BGD & 97.3 & 46.9 & 50.0 & 34.2 & 659 & 600.3 & 2666.0 & 75.9 & 34.7 & 1.2 & 0.5 & 310 & 16.8 & 15.2 & 14.3 & 36.1 & 3.4 & 29.0 & 4628.9 & 109.0 & 138.0 \\
\hline Barbados & BRB & 98.1 & 96.5 & 41.7 & 87.5 & 282 & $\mathrm{n} / \mathrm{a}$ & 1422.0 & 100.0 & 2.8 & $n / a$ & 4.5 & $\mathrm{n} / \mathrm{a}$ & $\mathrm{n} / \mathrm{a}$ & 3.7 & 6.8 & 7.7 & 24.8 & 88.0 & 2848.9 & 121.0 & 145.0 \\
\hline Belarus & BLR & 98.0 & 94.3 & 38.1 & 4.5 & 3589 & 27.6 & 618.0 & 100.0 & 6.8 & 0.8 & 6.7 & 3680 & 86.8 & 1.2 & 2.2 & 4.5 & 26.6 & 131.0 & 3207.5 & 131.0 & 573.0 \\
\hline Belgium & BEL & 100.0 & 99.5 & 77.5 & 50.0 & 1071 & 10.2 & 847.0 & 100.0 & 9.2 & 20.8 & 8.3 & 7709 & 80.1 & 1.2 & 0.8 & 2.6 & 24.5 & 163.0 & 6984.8 & 147.0 & 431.0 \\
\hline Belize & BLZ & 97.1 & 87.2 & 19.9 & 0.7 & 43390 & 13.7 & 1705.0 & 92.2 & 35.0 & 45.2 & 1.4 & $\mathrm{n} / \mathrm{a}$ & $\mathrm{n} / \mathrm{a}$ & 6.5 & 1.8 & 15.0 & 22.4 & 75.0 & 3164.6 & 122.0 & 453.0 \\
\hline Benin & BEN & 67.0 & 13.9 & 62.8 & 1.3 & 1001 & 13.1 & 1039.0 & 41.4 & 50.9 & 5.6 & 0.6 & 100 & 46.6 & 10.4 & 4.5 & 34.0 & 8.2 & 49.0 & 1455.9 & 123.0 & 214.0 \\
\hline Bhutan & BTN & 97.6 & 62.9 & 32.4 & 0.4 & 100457 & 54.1 & 2200.0 & 100.0 & 86.9 & 100.0 & 1.3 & $n / a$ & $n / a$ & $n / a$ & 5.9 & 33.6 & 5.8 & $n / a$ & 3410.4 & $n / a$ & 257.0 \\
\hline Bolivia & $\mathrm{BOL}$ & 92.9 & 52.6 & 49.4 & 0.7 & 28735 & 396.6 & 1146.0 & 93.0 & 17.5 & 31.4 & 1.9 & 753 & -178.0 & 19.8 & 2.0 & $\mathrm{n} / \mathrm{a}$ & 18.7 & 52.0 & 2092.4 & 105.0 & 355.0 \\
\hline Bosnia and Herzegovina & $\mathrm{BIH}$ & 97.7 & 94.8 & 60.9 & 0.9 & 9955 & 22.4 & 1028.0 & 100.0 & 40.8 & 35.5 & 6.2 & 3366 & 22.7 & 1.2 & 2.3 & 8.9 & 19.4 & 73.0 & 5191.7 & 128.0 & 252.0 \\
\hline Botswana & BWA & 79.2 & 60.0 & 41.1 & 8.1 & 1107 & 2.7 & 416.0 & 60.7 & 28.9 & 0.0 & 3.2 & 1749 & 44.5 & 28.5 & 7.2 & 31.4 & 16.1 & 64.0 & 452.8 & 98.0 & 172.0 \\
\hline Brazil & BRA & 97.5 & 86.1 & 50.7 & 1.3 & 27721 & \begin{tabular}{|l|}
6532.0 \\
\end{tabular} & \begin{tabular}{|l|}
1761.0 \\
\end{tabular} & 100.0 & 43.8 & 74.0 & 2.6 & 2601 & 11.9 & 1.2 & 1.6 & 7.1 & 22.3 & 116.0 & 4180.8 & 130.0 & 684.0 \\
\hline
\end{tabular}




\begin{tabular}{|c|c|c|c|c|c|c|c|c|c|c|c|c|c|c|c|c|c|c|c|c|c|c|}
\hline Brunei Darussalam & BRN & 99.5 & 96.3 & $\mathrm{n} / \mathrm{a}$ & 1.1 & 20646 & 5.8 & 2722.0 & 100.0 & 0.0 & 0.0 & 22.1 & 10243 & -357.4 & 2.6 & 2.9 & 19.7 & 14.7 & 82.0 & 844.2 & 124.0 & 116.0 \\
\hline Bulgaria & BGR & 99.3 & 86.0 & 60.2 & 27.2 & 2907 & 7.8 & 608.0 & 100.0 & 17.7 & 18.0 & 5.9 & 4709 & 36.6 & 3.0 & 3.2 & 8.8 & 27.4 & 94.0 & 4817.8 & 117.0 & 457.0 \\
\hline Burkina Faso & BFA & 53.9 & 22.5 & 62.6 & 6.5 & 711 & 3.0 & 748.0 & 19.2 & 74.2 & 9.4 & 0.2 & $\mathrm{n} / \mathrm{a}$ & $\mathrm{n} / \mathrm{a}$ & 21.3 & 7.6 & 27.3 & 4.5 & 61.0 & 1181.4 & 122.0 & 122.0 \\
\hline Cabo Verde & CPV & 86.5 & 65.2 & $\mathrm{n} / \mathrm{a}$ & 6.8 & 570 & $\mathrm{n} / \mathrm{a}$ & 228.0 & 92.6 & 26.6 & 20.2 & 0.9 & $\mathrm{n} / \mathrm{a}$ & $\mathrm{n} / \mathrm{a}$ & 12.3 & $\mathrm{n} / \mathrm{a}$ & $n / a$ & 10.6 & 69.0 & 178.0 & 113.0 & 73.0 \\
\hline Cambodia & KHM & 75.0 & 48.8 & 45.6 & 1.8 & 7897 & 265.4 & \begin{tabular}{|l|}
1904.0 \\
\end{tabular} & 49.8 & 64.9 & 46.4 & 0.4 & 271 & 33.1 & 18.5 & 9.6 & 32.4 & 3.5 & 34.0 & 3459.9 & 108.0 & 281.0 \\
\hline Cameroon & CMR & 65.3 & 38.8 & 33.8 & 0.4 & 12275 & 213.4 & 1604.0 & 60.1 & 76.5 & 76.1 & 0.3 & 281 & -28.3 & 7.3 & 5.2 & 31.7 & 9.5 & 56.0 & 1643.7 & 126.0 & 244.0 \\
\hline Canada & CAN & 98.9 & 98.5 & $\mathrm{n} / \mathrm{a}$ & 1.4 & 80202 & \begin{tabular}{|l|l|}
1931.0 \\
\end{tabular} & 537.0 & 100.0 & 22.0 & 63.0 & 15.1 & 15546 & -72.5 & 1.2 & 0.8 & 2.6 & 31.3 & 148.0 & 3908.8 & 140.0 & 746.0 \\
\hline Central African Republic & $\mathrm{CAF}$ & 54.1 & 25.1 & 31.0 & 0.1 & 31227 & 119.4 & 1343.0 & 14.0 & 76.6 & 99.4 & 0.1 & $\mathrm{n} / \mathrm{a}$ & $\mathrm{n} / \mathrm{a}$ & 61.8 & 7.4 & 40.7 & 6.3 & 62.0 & 879.8 & 79.0 & 202.0 \\
\hline Chad & $T C D$ & 42.5 & 9.5 & 31.8 & 5.9 & 1105 & 25.2 & 322.0 & 8.8 & 89.4 & $n / a$ & 0.1 & $\mathrm{n} / \mathrm{a}$ & $\mathrm{n} / \mathrm{a}$ & 39.7 & 13.0 & 39.9 & 4.8 & 47.0 & 844.7 & 98.0 & 154.0 \\
\hline Chile & $\mathrm{CHL}$ & 100.0 & 99.9 & 22.6 & 4.0 & 50245 & 529.3 & 1522.0 & 100.0 & 24.9 & 43.6 & 4.7 & 3912 & 65.2 & 3.3 & 0.3 & 1.8 & 28.8 & 86.0 & 6858.2 & 125.0 & 455.0 \\
\hline China & $\mathrm{CHN}$ & $\mathrm{n} / \mathrm{a}$ & $\mathrm{n} / \mathrm{a}$ & 74.5 & 21.3 & 2062 & 1471.0 & \begin{tabular}{|l|}
645.0 \\
\end{tabular} & 100.0 & 12.4 & 23.9 & 7.5 & 3927 & 15.0 & 8.7 & $\mathrm{n} / \mathrm{a}$ & $\mathrm{n} / \mathrm{a}$ & 6.6 & 95.0 & 6029.2 & 131.0 & 379.0 \\
\hline Colombia & $\mathrm{COL}$ & 96.5 & 84.4 & 50.4 & 0.5 & 44882 & 1692.0 & 3240.0 & 99.0 & 23.6 & 68.2 & 1.8 & 1290 & -274.1 & 6.5 & 0.9 & 12.7 & 22.1 & 80.0 & 4191.8 & 127.0 & 282.0 \\
\hline Comoros & $\mathrm{COM}$ & 83.7 & 34.2 & 25.7 & 0.8 & 1580 & $\mathrm{n} / \mathrm{a}$ & 900.0 & 77.8 & 45.3 & $\mathrm{n} / \mathrm{a}$ & 0.2 & $\mathrm{n} / \mathrm{a}$ & $\mathrm{n} / \mathrm{a}$ & $\mathrm{n} / \mathrm{a}$ & 11.1 & 32.1 & 6.9 & $\mathrm{n} / \mathrm{a}$ & 1355.8 & 105.0 & 90.0 \\
\hline Congo, Dem. Rep. & COD & 41.8 & 19.7 & 31.3 & 0.1 & 12208 & 981.7 & 1543.0 & 17.1 & 95.8 & 99.8 & 0.1 & 109 & 2.0 & $\mathrm{n} / \mathrm{a}$ & 8.1 & $\mathrm{n} / \mathrm{a}$ & 5.6 & $\mathrm{n} / \mathrm{a}$ & 771.5 & $\mathrm{n} / \mathrm{a}$ & 51.0 \\
\hline Congo, Rep. & $\mathrm{COG}$ & 68.3 & 15.0 & 32.0 & 0.0 & 45575 & 664.4 & 1646.0 & 56.6 & 62.4 & 53.3 & 0.6 & 197 & -496.6 & 37.5 & 8.2 & $\mathrm{n} / \mathrm{a}$ & 8.4 & 46.0 & 828.2 & 94.0 & 87.0 \\
\hline Costa Rica & CRI & 99.7 & 97.1 & 43.3 & 2.1 & 23752 & 54.4 & 2926.0 & 100.0 & 38.7 & 99.0 & 1.6 & 1958 & 49.8 & 4.4 & 1.0 & 5.6 & 25.7 & 89.0 & 4027.0 & 119.0 & 634.0 \\
\hline Cote d'Ivoire & CIV & 73.1 & 29.9 & 32.1 & 2.0 & 3410 & 61.3 & 1348.0 & 64.3 & 64.5 & 16.7 & 0.5 & 276 & 7.1 & 20.7 & 6.0 & $\mathrm{n} / \mathrm{a}$ & 9.0 & 58.0 & 2133.9 & 119.0 & 271.0 \\
\hline Croatia & HRV & 99.6 & 97.5 & 89.8 & 1.7 & 8895 & 60.5 & 1113.0 & 100.0 & 33.1 & 66.8 & 4.0 & 3714 & 45.9 & 1.2 & 0.8 & 2.6 & 27.1 & 112.0 & 6742.3 & 123.0 & 351.0 \\
\hline Cuba & CUB & 95.2 & 90.8 & 80.4 & 18.3 & 3332 & 9.1 & 1335.0 & 100.0 & 19.3 & 3.9 & 3.0 & 1434 & 49.8 & 1.2 & 2.4 & 7.0 & 26.7 & 66.0 & 2939.3 & 147.0 & 254.0 \\
\hline Cyprus & CYP & 100.0 & 99.4 & 90.7 & 28.4 & 677 & 0.0 & 498.0 & 100.0 & 9.9 & 8.8 & 5.3 & 3625 & 94.0 & 4.6 & 0.8 & 2.6 & 22.6 & 118.0 & 2191.0 & 108.0 & 269.0 \\
\hline Czech Republic & CZE & 99.9 & 99.1 & 79.3 & 12.5 & 1249 & 6.6 & 677.0 & 100.0 & 14.8 & 11.4 & 9.2 & 6259 & 31.6 & 1.2 & 4.6 & $\mathrm{n} / \mathrm{a}$ & 28.5 & 135.0 & 6317.3 & 128.0 & 347.0 \\
\hline Denmark & DNK & 100.0 & 99.6 & 93.0 & 10.6 & 1063 & 2.3 & 703.0 & 100.0 & 33.2 & 65.5 & 5.9 & 5859 & 1.8 & 1.2 & 0.8 & 2.6 & 21.3 & 133.0 & 6222.0 & 132.0 & 1067.0 \\
\hline Djibouti & DJI & 76.9 & 51.4 & $\mathrm{n} / \mathrm{a}$ & 6.3 & 329 & $\mathrm{n} / \mathrm{a}$ & 220.0 & 51.8 & 15.4 & $\mathrm{n} / \mathrm{a}$ & 0.8 & $\mathrm{n} / \mathrm{a}$ & $\mathrm{n} / \mathrm{a}$ & 19.7 & 21.5 & 33.5 & 12.2 & 59.0 & 1925.6 & 108.0 & 78.0 \\
\hline Dominica & DMA & 96.5 & 77.9 & 40.0 & 10.0 & 2748 & $n / a$ & 2083.0 & 100.0 & 7.8 & 16.2 & 1.9 & $n / a$ & $\mathrm{n} / \mathrm{a}$ & 5.2 & $n / a$ & $\mathrm{n} / \mathrm{a}$ & 28.2 & 77.0 & 1696.2 & 122.0 & 371.0 \\
\hline Dominican Republic & DOM & 94.5 & 82.7 & 35.5 & 30.4 & 2258 & 5.5 & 1410.0 & 100.0 & 16.5 & 11.6 & 2.1 & 1578 & 86.7 & 10.4 & 2.4 & 7.1 & 26.9 & 90.0 & 4761.1 & 114.0 & 291.0 \\
\hline Ecuador & ECU & 92.6 & 86.1 & 41.8 & 2.2 & 27818 & 296.2 & 2274.0 & 99.9 & 13.8 & 52.8 & 2.8 & 1381 & -114.7 & 7.8 & 1.6 & 23.9 & 19.3 & 93.0 & 3575.5 & 115.0 & 372.0 \\
\hline Egypt & EGY & 98.4 & 93.2 & 40.3 & 4100.0 & 20 & \begin{tabular}{l|l|}
2.6 \\
\end{tabular} & 51.0 & 100.0 & 5.7 & 8.3 & 2.2 & 1658 & -7.4 & 4.8 & 9.5 & 22.3 & 31.1 & 64.0 & 7114.0 & 152.0 & 238.0 \\
\hline El Salvador & SLV & 93.0 & 91.1 & 21.3 & 13.6 & 2488 & 10.2 & 1784.0 & 98.6 & 24.4 & 57.8 & 1.0 & 939 & 49.2 & 10.3 & 2.1 & 13.6 & 22.7 & 59.0 & 2745.5 & 116.0 & 153.0 \\
\hline Estonia & EST & 99.6 & 99.6 & 80.0 & 13.5 & 9669 & 3.6 & 626.0 & 100.0 & 27.5 & 14.4 & 14.8 & 6732 & -2.7 & 2.8 & $\mathrm{n} / \mathrm{a}$ & 2.6 & 23.8 & 91.0 & 2658.4 & 128.0 & 432.0 \\
\hline Ethiopia & ETH & 39.1 & 7.1 & 31.3 & 6.4 & 1253 & 89.3 & 848.0 & 42.9 & 92.2 & 100.0 & 0.1 & 70 & 5.9 & 21.4 & 9.9 & 38.4 & 3.6 & 26.0 & 2484.0 & 105.0 & 114.0 \\
\hline Fiji & $\mathrm{FJI}$ & 93.7 & 95.7 & $\mathrm{n} / \mathrm{a}$ & 0.3 & 32231 & $\mathrm{n} / \mathrm{a}$ & 2592.0 & 98.6 & 31.3 & 45.0 & 1.3 & $\mathrm{n} / \mathrm{a}$ & $\mathrm{n} / \mathrm{a}$ & 4.4 & 6.3 & 7.5 & 30.0 & 93.0 & \begin{tabular}{|l|l|}
3017.8 \\
\end{tabular} & 124.0 & 218.0 \\
\hline Finland & FIN & 100.0 & 99.4 & 74.6 & 6.1 & 19592 & 67.8 & 536.0 & 100.0 & 43.2 & 44.5 & 8.7 & 15250 & 45.3 & 1.2 & 0.8 & 2.6 & 24.9 & 138.0 & \begin{tabular}{|l|}
3574.1 \\
\end{tabular} & 132.0 & 348.0 \\
\hline France & FRA & 100.0 & 98.7 & 100.0 & 14.9 & 3016 & 96.8 & 867.0 & 100.0 & 13.5 & 15.9 & 4.6 & 6940 & 44.1 & 1.2 & 0.8 & 2.6 & 23.2 & 159.0 & 5686.8 & 140.0 & 597.0 \\
\hline Gabon & GAB & 87.5 & 40.9 & 14.4 & 0.1 & 87433 & 138.3 & \begin{tabular}{|l|l|}
1831.0 \\
\end{tabular} & 91.4 & 82.0 & 43.7 & 2.8 & 1173 & -213.4 & 9.4 & 3.4 & 17.5 & 13.4 & 58.0 & 1604.0 & 124.0 & 136.0 \\
\hline
\end{tabular}




\begin{tabular}{|c|c|c|c|c|c|c|c|c|c|c|c|c|c|c|c|c|c|c|c|c|c|c|}
\hline Gambia, The & GMB & 80.1 & 41.7 & 29.8 & 3.0 & 1564 & 3.4 & 836.0 & 47.8 & 51.5 & $n / a$ & 0.3 & $n / a$ & $\mathrm{n} / \mathrm{a}$ & 9.6 & 11.1 & $n / a$ & 8.7 & 72.0 & 840.7 & 120.0 & 68.0 \\
\hline Georgia & GEO & 93.3 & 84.9 & 35.1 & 3.1 & 15597 & 32.6 & 1026.0 & 100.0 & 28.7 & 78.0 & 2.4 & 2688 & 68.8 & 7.4 & 1.6 & 11.3 & 23.3 & 64.0 & 2517.2 & 115.0 & 163.0 \\
\hline Germany & DEU & 100.0 & 99.2 & 88.0 & 30.8 & 1321 & 81.0 & 700.0 & 100.0 & 14.2 & 29.2 & 8.9 & 7035 & 61.4 & 1.2 & 1.0 & 1.3 & 25.7 & 143.0 & 7182.1 & 137.0 & 415.0 \\
\hline Ghana & GHA & 77.8 & 14.3 & 48.6 & 3.2 & 1124 & 33.3 & 1187.0 & 79.3 & 41.4 & 50.9 & 0.5 & 355 & -8.2 & 6.1 & 4.7 & 18.8 & 9.7 & 46.0 & 1842.4 & 135.0 & 287.0 \\
\hline Greece & GRC & 100.0 & 99.0 & 83.2 & 16.5 & 5325 & 19.0 & 652.0 & 100.0 & 17.2 & 28.7 & 6.2 & 5063 & 64.2 & 1.2 & 0.8 & 2.6 & 27.4 & 149.0 & \begin{tabular}{|l|l|}
4144.8 \\
\end{tabular} & 135.0 & 592.0 \\
\hline Guatemala & GTM & 93.6 & 67.4 & 24.9 & 3.0 & 6858 & 70.0 & 1996.0 & 91.8 & 63.7 & 60.4 & 1.2 & 578 & 32.8 & 15.8 & 0.7 & 46.5 & 18.8 & 56.0 & 2152.3 & 114.0 & 302.0 \\
\hline Guinea & GIN & 67.4 & 22.0 & 24.1 & 0.2 & 19144 & 161.0 & 1651.0 & 33.5 & 76.3 & 78.8 & 0.2 & $\mathrm{n} / \mathrm{a}$ & $\mathrm{n} / \mathrm{a}$ & 19.7 & 8.1 & 32.4 & 6.6 & 61.0 & 1180.0 & 115.0 & 174.0 \\
\hline Guinea-Bissau & GNB & 69.2 & 21.5 & $n / a$ & 1.1 & 9271 & 19.7 & 1577.0 & 14.7 & 86.9 & $n / a$ & 0.2 & $n / a$ & n/a & 26.0 & 6.0 & 27.6 & 8.2 & 63.0 & 1426.4 & 102.0 & 213.0 \\
\hline Guyana & GUY & 95.1 & 86.2 & 15.6 & 0.6 & 315696 & \begin{tabular}{|l|}
227.2 \\
\end{tabular} & \begin{tabular}{|l|}
2387.0 \\
\end{tabular} & 84.2 & 25.3 & $n / a$ & 2.6 & $n / a$ & $n / a$ & 7.5 & 6.4 & 12.0 & 19.2 & 58.0 & 3516.0 & 121.0 & 545.0 \\
\hline Haiti & $\mathrm{HTI}$ & 64.2 & 30.5 & 29.4 & 11.1 & 1231 & 3.2 & 1440.0 & 38.7 & 76.1 & 8.0 & 0.3 & 39 & 22.0 & 45.8 & 5.2 & 21.9 & 20.5 & 49.0 & 1012.7 & 96.0 & 135.0 \\
\hline Honduras & HND & 92.2 & 79.8 & 20.5 & 1.8 & 10291 & 57.4 & 1976.0 & 87.6 & 51.5 & 42.3 & 1.1 & 630 & 53.0 & 15.3 & 1.4 & 22.7 & 19.4 & 72.0 & 1748.1 & 116.0 & 194.0 \\
\hline Hong Kong SAR, China & HKG & 100.0 & 96.3 & $\mathrm{n} / \mathrm{a}$ & $\mathrm{n} / \mathrm{a}$ & $\mathrm{n} / \mathrm{a}$ & $\mathrm{n} / \mathrm{a}$ & $\mathrm{n} / \mathrm{a}$ & 100.0 & 0.9 & 0.3 & 6.4 & 6083 & 98.7 & 1.2 & 0.8 & $\mathrm{n} / \mathrm{a}$ & $n / a$ & 136.0 & 2000.0 & 134.0 & 5.0 \\
\hline Hungary & HUN & 100.0 & 98.0 & 73.3 & 84.2 & 608 & 46.1 & 589.0 & 100.0 & 15.6 & 10.6 & 4.3 & 3966 & 57.7 & 1.2 & 0.8 & 2.6 & 28.6 & 135.0 & 5099.2 & 120.0 & 549.0 \\
\hline Iceland & ISL & 100.0 & 98.8 & 51.9 & 2.1 & 519265 & 96.4 & 1940.0 & 100.0 & 77.0 & 100.0 & 6.1 & 53832 & 11.6 & 1.2 & $\mathrm{n} / \mathrm{a}$ & 2.6 & 23.1 & 148.0 & $\mathrm{n} / \mathrm{a}$ & 136.0 & 344.0 \\
\hline India & IND & 87.6 & 44.2 & $\mathrm{n} / \mathrm{a}$ & 44.8 & 1118 & 937.1 & 1083.0 & 84.5 & 36.0 & 15.3 & 1.7 & 806 & 34.3 & 14.8 & 21.0 & 38.4 & 3.8 & 52.0 & 2992.8 & 108.0 & 186.0 \\
\hline Indonesia & IDN & 89.5 & 67.9 & 48.2 & 5.6 & 7914 & 1269.0 & 2702.0 & 97.6 & 36.9 & 10.7 & 1.8 & 812 & -103.1 & 7.7 & 13.5 & 36.4 & 6.9 & 56.0 & 5405.5 & 124.0 & 243.0 \\
\hline Iran, Islamic Rep. & IRN & 94.9 & 88.3 & 59.0 & 72.5 & 1639 & 22.7 & 228.0 & 100.0 & 0.9 & 5.1 & 8.3 & 2986 & -33.4 & 4.9 & 4.0 & n/a & 25.5 & 74.0 & 2166.4 & 131.0 & 318.0 \\
\hline Iraq & IRQ & 86.1 & 85.7 & 25.1 & 187.5 & 1006 & 18.7 & 216.0 & 100.0 & 0.8 & 3.7 & 4.8 & 1306 & -229.4 & 27.7 & 7.4 & 22.6 & 27.4 & 65.0 & 3100.6 & 111.0 & 53.0 \\
\hline Ireland & IRL & 98.9 & 92.2 & 80.5 & 1.5 & 10520 & 31.2 & 1118.0 & 100.0 & 9.1 & 28.0 & 7.3 & 5672 & 85.7 & 1.2 & $n / a$ & 2.6 & 26.9 & 128.0 & 8223.3 & 146.0 & 976.0 \\
\hline Israel & ISR & 100.0 & 100.0 & 85.0 & 189.2 & 91 & 0.6 & 435.0 & 100.0 & 3.7 & 1.9 & 7.9 & 6601 & 65.0 & 1.2 & 0.8 & 2.6 & 26.7 & 150.0 & 4969.5 & 158.0 & 342.0 \\
\hline Italy & ITA & 100.0 & 99.3 & 54.5 & 29.5 & 3002 & 77.8 & 832.0 & 100.0 & 16.5 & 38.7 & 5.3 & 5002 & 76.4 & 1.2 & 0.8 & 2.6 & 22.9 & 156.0 & 5599.0 & 142.0 & 471.0 \\
\hline Jamaica & JAM & 92.9 & 85.4 & 42.9 & 7.5 & 3780 & $n / a$ & 2051.0 & 98.2 & 16.8 & 10.3 & 2.6 & 1056 & 82.0 & 8.9 & 3.6 & 6.2 & 24.4 & 76.0 & 1090.1 & 113.0 & 192.0 \\
\hline Japan & JPN & 98.9 & 100.0 & 93.9 & 18.9 & 3378 & 212.5 & 1668.0 & 100.0 & 6.3 & 16.0 & 9.5 & 7820 & 93.0 & 1.2 & 2.3 & 7.1 & 4.4 & 87.0 & 4975.5 & 113.0 & 133.0 \\
\hline Jordan & JOR & 98.6 & 96.7 & 63.4 & 124.5 & 77 & 0.0 & \begin{tabular}{|l|}
111.0 \\
\end{tabular} & 100.0 & 3.2 & 1.0 & 3.0 & 1888 & 96.8 & 13.5 & 2.4 & 7.8 & 33.4 & 100.0 & \begin{tabular}{|l|}
1530.7 \\
\end{tabular} & 112.0 & 152.0 \\
\hline Kazakhstan & KAZ & 91.1 & 97.8 & 30.2 & 31.0 & 3722 & 36.3 & 250.0 & 100.0 & 1.6 & 8.9 & 14.4 & 5600 & -116.9 & 1.2 & 3.1 & 8.0 & 21.3 & 132.0 & \begin{tabular}{|l|}
1347.7 \\
\end{tabular} & 138.0 & 430.0 \\
\hline Kenya & KEN & 58.5 & 29.8 & 52.6 & 15.5 & 450 & 18.6 & 630.0 & 56.0 & 72.7 & 87.5 & 0.3 & 167 & 17.2 & 24.2 & 4.0 & 26.0 & 6.0 & 47.0 & 1390.7 & 101.0 & 149.0 \\
\hline Korea, Dem. People's Rep. & PRK & 99.6 & 77.1 & 38.5 & 12.9 & 2668 & 45.9 & 1054.0 & 39.2 & 23.1 & 72.8 & 1.6 & 600 & -74.8 & 43.4 & 4.0 & $\mathrm{n} / \mathrm{a}$ & 7.1 & 35.0 & 4083.1 & 87.0 & 142.0 \\
\hline Korea, Rep. & KOR & 99.6 & 99.9 & 67.9 & 44.8 & 1278 & 35.4 & 1274.0 & 100.0 & 2.7 & 1.9 & 11.6 & 10497 & 81.4 & 1.2 & 1.2 & $\mathrm{n} / \mathrm{a}$ & 4.9 & 103.0 & 6795.2 & 135.0 & 202.0 \\
\hline Kuwait & KWT & 100.0 & 100.0 & 81.5 & $\mathrm{n} / \mathrm{a}$ & 3 & $\mathrm{n} / \mathrm{a}$ & 121.0 & 100.0 & $n / a$ & n/a & 25.2 & 15213 & -391.1 & 1.2 & 3.1 & 4.9 & 37.0 & 115.0 & 13345 & 141.0 & 90.0 \\
\hline Lao PDR & LAO & 80.4 & 72.6 & $\mathrm{n} / \mathrm{a}$ & 1.8 & 28952 & 180.1 & 1834.0 & 87.1 & 59.3 & 86.4 & 0.3 & $\mathrm{n} / \mathrm{a}$ & $\mathrm{n} / \mathrm{a}$ & 16.6 & 6.4 & $\mathrm{n} / \mathrm{a}$ & 4.5 & 37.0 & 4626.7 & 106.0 & 355.0 \\
\hline Latvia & LVA & 98.6 & 92.9 & 64.3 & 1.4 & 8496 & 18.0 & 641.0 & 100.0 & 38.1 & 50.2 & 3.5 & 3507 & 45.2 & 1.2 & $\mathrm{n} / \mathrm{a}$ & 2.6 & 25.7 & 118.0 & 3828.4 & 129.0 & 471.0 \\
\hline Lebanon & LBN & 92.3 & 95.4 & 32.2 & 22.8 & 857 & 1.4 & 661.0 & 100.0 & 3.6 & 2.6 & 4.3 & 2893 & 97.9 & 10.9 & 6.6 & 16.5 & 31.3 & 102.0 & 3013.2 & 114.0 & 186.0 \\
\hline Lesotho & LSO & 71.6 & 43.8 & 32.9 & 0.8 & 2437 & 1.3 & 788.0 & 29.7 & 52.1 & 100.0 & 1.2 & $n / a$ & n/a & 12.8 & 2.8 & 33.2 & 13.5 & 32.0 & 508.3 & 114.0 & 73.0 \\
\hline Liberia & LBR & 69.9 & 16.9 & 15.0 & 0.1 & 45550 & 176.8 & \begin{tabular}{|l|}
2391.0 \\
\end{tabular} & 19.8 & 83.8 & $\mathrm{n} / \mathrm{a}$ & 0.2 & $n / a$ & n/a & 38.8 & 5.6 & 32.1 & 8.6 & 60.0 & 1322.3 & 101.0 & 74.0 \\
\hline
\end{tabular}




\begin{tabular}{|c|c|c|c|c|c|c|c|c|c|c|c|c|c|c|c|c|c|c|c|c|c|c|}
\hline Libya & LBY & 96.8 & 99.7 & 46.9 & 822.9 & 113 & $n / a$ & 56.0 & 98.5 & 2.0 & $n / a$ & 9.2 & 1857 & -103.0 & $n / a$ & 6.5 & 21.0 & 31.8 & $\mathrm{n} / \mathrm{a}$ & 715.0 & 140.0 & 181.0 \\
\hline Lithuania & LTU & 97.4 & 93.6 & 56.6 & 4.1 & 5272 & 10.6 & 656.0 & 100.0 & 29.0 & 39.4 & 4.4 & 3821 & 75.0 & 1.2 & $n / a$ & 2.6 & 28.4 & 96.0 & 3853.0 & 138.0 & 675.0 \\
\hline Luxembourg & LUX & 100.0 & 97.6 & 90.2 & 4.3 & 1798 & 2.3 & 934.0 & 100.0 & 9.0 & 32.4 & 17.4 & 13915 & 96.3 & 1.2 & 0.8 & 2.6 & 24.2 & 139.0 & |4999.6 & 138.0 & 343.0 \\
\hline Macedonia, FYR & MKD & 96.8 & 90.9 & $n / a$ & 10.2 & 2599 & $n / a$ & 619.0 & 100.0 & 24.2 & 35.9 & 3.6 & 3497 & 51.8 & 4.1 & 1.8 & $n / a$ & 23.9 & 102.0 & 3858.8 & 118.0 & 371.0 \\
\hline Madagascar & MDG & 50.6 & 9.7 & 36.5 & 4.0 & 14286 & 217.5 & 1513.0 & 22.9 & 70.2 & 54.6 & 0.1 & $n / a$ & $\mathrm{n} / \mathrm{a}$ & 43.1 & 15.2 & 49.2 & 4.5 & 24.0 & 3920.3 & 89.0 & 137.0 \\
\hline Malawi & MWI & 67.2 & 43.5 & 40.3 & 8.4 & 946 & 9.5 & 1181.0 & 11.0 & 83.6 & 91.3 & 0.1 & $n / a$ & $n / a$ & 26.3 & 2.7 & 37.1 & 4.7 & 39.0 & 1347.4 & 104.0 & 139.0 \\
\hline Malaysia & MYS & 96.4 & 99.6 & 42.8 & 1.9 & 19187 & 385.0 & 2875.0 & 100.0 & 5.2 & 10.0 & 8.0 & 4596 & -5.5 & 2.9 & 11.5 & 20.7 & 15.3 & 88.0 & 3226.5 & 125.0 & 470.0 \\
\hline Maldives & MDV & 97.9 & 95.9 & 35.5 & 15.7 & 73 & $n / a$ & 1972.0 & 100.0 & 1.0 & 1.3 & 3.3 & $\mathrm{n} / \mathrm{a}$ & $n / a$ & 11.0 & 10.2 & 20.3 & 7.9 & 62.0 & 2445.9 & 115.0 & 18.0 \\
\hline Mali & MLI & 74.3 & 31.3 & 53.3 & 8.6 & 3537 & 55.2 & 282.0 & 35.1 & 61.5 & 43.5 & 0.1 & $n / a$ & $\mathrm{n} / \mathrm{a}$ & 6.0 & 13.5 & 30.4 & 7.1 & 62.0 & 1607.5 & 142.0 & 244.0 \\
\hline Malta & MLT & 100.0 & 100.0 & 75.3 & 44.4 & 116 & $n / a$ & 560.0 & 100.0 & 5.4 & 7.7 & 5.4 & 4925 & 98.4 & 1.2 & 0.8 & 2.6 & 31.0 & 115.0 & 4744.9 & 134.0 & 169.0 \\
\hline Mauritania & MRT & 69.6 & 44.6 & 45.4 & 337.0 & 98 & 1.2 & 92.0 & 41.7 & 32.2 & 13.4 & 0.7 & $n / a$ & $\mathrm{n} / \mathrm{a}$ & 11.3 & 14.8 & 27.9 & 11.3 & 78.0 & \begin{tabular}{|l|}
1221.6 \\
\end{tabular} & 126.0 & 153.0 \\
\hline Mauritius & MUS & 99.9 & 93.1 & 64.4 & 26.4 & 2182 & $n / a$ & 2041.0 & 98.8 & 11.5 & 22.7 & 3.4 & 2183 & 84.5 & 5.8 & $n / a$ & $n / a$ & 11.5 & 92.0 & 3455.0 & 125.0 & 190.0 \\
\hline Mexico & MEX & 98.3 & 89.2 & 49.5 & 20.0 & 3293 & 195.3 & 758.0 & 100.0 & 9.2 & 15.4 & 3.9 & 2090 & -4.7 & 3.8 & 1.0 & 12.4 & 28.4 & 92.0 & \begin{tabular}{|l|l|}
3748.8 \\
\end{tabular} & 132.0 & 293.0 \\
\hline Moldova & MDA & 86.7 & 78.4 & $\mathrm{n} / \mathrm{a}$ & 65.7 & 456 & 5.5 & 450.0 & 100.0 & 14.3 & 5.4 & 1.4 & 1386 & 90.0 & $\mathrm{n} / \mathrm{a}$ & 1.9 & $\mathrm{n} / \mathrm{a}$ & 20.1 & 85.0 & 3196.7 & 105.0 & 314.0 \\
\hline Mongolia & $\mathrm{MNG}$ & 83.2 & 59.2 & 43.0 & 1.6 & 11902 & 21.2 & 241.0 & 81.8 & 3.4 & 3.1 & 7.1 & 2018 & -168.1 & 18.7 & 1.0 & 10.8 & 19.6 & 88.0 & \begin{tabular}{|l|}
1279.4 \\
\end{tabular} & 106.0 & 315.0 \\
\hline Montenegro & MNE & 97.6 & 95.9 & 34.4 & $\mathrm{n} / \mathrm{a}$ & $\mathrm{n} / \mathrm{a}$ & $n / a$ & 241.0 & 100.0 & 43.0 & 49.7 & 3.6 & 4612 & 27.6 & 1.2 & 2.8 & 9.4 & 24.9 & 129.0 & 3261.7 & 141.0 & 156.0 \\
\hline Morocco & MAR & 83.0 & 83.5 & 63.9 & 35.7 & 845 & 8.2 & 346.0 & 100.0 & 11.3 & 14.3 & 1.7 & 901 & 90.7 & 3.9 & 2.3 & 14.9 & 25.6 & 68.0 & 936.2 & 147.0 & 250.0 \\
\hline Mozambique & $\mathrm{MOZ}$ & 47.3 & 23.6 & 54.6 & 0.9 & 3686 & 133.0 & 1032.0 & 24.2 & 86.4 & 86.4 & 0.3 & 463 & -54.6 & 30.5 & 6.1 & 43.1 & 6.0 & 41.0 & 823.8 & 106.0 & 97.0 \\
\hline Myanmar & MMR & 67.5 & 64.7 & 27.3 & 3.3 & 19317 & 595.0 & 2091.0 & 57.0 & 61.5 & 58.9 & 0.4 & 217 & -33.0 & 10.5 & 7.0 & 29.2 & 5.7 & 70.0 & 3607.4 & 118.0 & 323.0 \\
\hline Namibia & NAM & $n / a$ & $n / a$ & 59.1 & 4.6 & 2598 & 7.2 & 285.0 & 51.8 & 26.5 & 97.8 & 1.6 & 1585 & 74.4 & 25.4 & $n / a$ & $n / a$ & 15.0 & 49.0 & 453.1 & 98.0 & 168.0 \\
\hline Nepal & NPL & 87.7 & 46.1 & 32.9 & 4.8 & 6998 & 95.9 & 1500.0 & 90.7 & 85.3 & 100.0 & 0.3 & 139 & 16.7 & 9.5 & 9.7 & 35.8 & 3.8 & 53.0 & 2605.4 & 118.0 & 203.0 \\
\hline Netherlands & NLD & 100.0 & 97.7 & 93.2 & 97.5 & 652 & 38.3 & 778.0 & 100.0 & 5.9 & 12.4 & 9.9 & 6713 & 35.0 & 1.2 & 0.8 & 2.6 & 23.1 & 124.0 & 7776.9 & 125.0 & 810.0 \\
\hline New Zealand & NZL & 100.0 & 100.0 & 57.6 & 1.6 & 72510 & 204.3 & 1732.0 & 100.0 & 30.8 & 80.1 & 7.7 & 9026 & 19.5 & 1.2 & 0.8 & 2.6 & 32.0 & 117.0 & 8383.8 & 123.0 & 2425.0 \\
\hline Nicaragua & NIC & 82.3 & 76.3 & $n / a$ & 1.0 & 25973 & 107.2 & 2280.0 & 81.8 & 48.2 & 50.1 & 0.8 & 580 & 40.9 & 16.2 & 2.2 & 17.3 & 21.8 & 60.0 & \begin{tabular}{|l|l|}
1768.0 \\
\end{tabular} & 117.0 & 238.0 \\
\hline Niger & NER & 45.8 & 12.9 & 49.7 & 28.1 & 183 & 10.6 & 151.0 & 16.2 & 78.9 & 0.8 & 0.1 & 51 & -5.8 & 14.4 & 10.3 & 42.2 & 4.7 & 55.0 & 530.3 & 123.0 & 180.0 \\
\hline Nigeria & NGA & 67.3 & 32.6 & 35.1 & 5.6 & 1252 & 157.2 & 1150.0 & 59.3 & 86.6 & 18.2 & 0.5 & 144 & -93.0 & 11.5 & 10.8 & 43.6 & 7.8 & 57.0 & 1443.6 & 117.0 & 211.0 \\
\hline Norway & NOR & 100.0 & 98.1 & 63.4 & 0.8 & 74359 & 261.5 & 1414.0 & 100.0 & 57.8 & 97.7 & 9.3 & 23000 & -581.3 & 1.2 & 0.8 & 2.6 & 25.0 & 150.0 & 4607.8 & 136.0 & 260.0 \\
\hline Oman & OMN & 90.9 & 99.3 & 33.2 & 84.7 & 353 & $n / a$ & 125.0 & 100.0 & $n / a$ & $n / a$ & 15.4 & 6554 & -206.2 & 5.4 & 7.5 & 14.1 & 22.9 & 87.0 & 5689.9 & 125.0 & 114.0 \\
\hline Pakistan & PAK & 88.5 & 58.3 & 49.8 & 333.6 & 296 & 83.8 & 494.0 & 99.1 & 46.5 & 31.4 & 0.9 & 471 & 24.1 & 20.5 & 10.5 & 45.0 & 7.8 & 74.0 & 3064.2 & 108.0 & 196.0 \\
\hline Panama & PAN & 95.0 & 76.9 & 36.7 & 0.8 & 34990 & 4.9 & 2928.0 & 93.4 & 21.2 & 65.3 & 2.3 & 2063 & 80.9 & 9.2 & 1.2 & 19.1 & 22.5 & 76.0 & \begin{tabular}{|l|}
2569.7 \\
\end{tabular} & 122.0 & 238.0 \\
\hline Papua New Guinea & PNG & 36.6 & 18.6 & 25.0 & 0.0 & 103278 & 504.5 & 3142.0 & 22.9 & 52.5 & 34.5 & 0.8 & $\mathrm{n} / \mathrm{a}$ & $\mathrm{n} / \mathrm{a}$ & $\mathrm{n} / \mathrm{a}$ & 14.3 & 49.5 & 19.4 & $\mathrm{n} / \mathrm{a}$ & \begin{tabular}{|l|l|}
4737.8 \\
\end{tabular} & 100.0 & 351.0 \\
\hline Paraguay & PRY & 98.9 & 91.2 & 31.9 & 2.1 & 17856 & 256.3 & 1130.0 & 98.4 & 61.7 & 100.0 & 0.9 & 1564 & -36.9 & 11.2 & 1.0 & 5.6 & 19.0 & 92.0 & 4425.5 & 111.0 & 855.0 \\
\hline Peru & PER & 89.9 & 76.8 & 29.6 & 0.8 & 52981 & 1343.0 & 1738.0 & 94.9 & 25.5 & 52.7 & 2.0 & 1308 & -14.9 & 8.8 & 1.0 & 13.1 & 19.1 & 50.0 & 4187.7 & 117.0 & 292.0 \\
\hline Philippines & PHL & 90.5 & 75.0 & 51.0 & 17.0 & 4785 & 151.9 & $2348.0 \mid$ & 91.0 & 27.5 & 25.4 & 1.1 & 699 & 45.8 & 13.7 & 7.1 & 33.4 & 6.0 & 52.0 & 3529.0 & 117.0 & 196.0 \\
\hline
\end{tabular}




\begin{tabular}{|c|c|c|c|c|c|c|c|c|c|c|c|c|c|c|c|c|c|c|c|c|c|c|}
\hline Poland & $\mathrm{POL}$ & 97.9 & 98.1 & 39.5 & 21.4 & 1410 & 31.6 & 600.0 & 100.0 & 11.9 & 13.8 & 7.5 & 3972 & 28.5 & 1.2 & 0.8 & 2.6 & 25.6 & 118.0 & 3999.9 & 137.0 & 491.0 \\
\hline Portugal & PRT & 99.9 & 99.4 & 74.1 & 24.1 & 3653 & 27.6 & 854.0 & 100.0 & 27.2 & 47.5 & 4.3 & 4663 & 76.9 & 1.2 & 0.8 & 2.6 & 23.2 & 140.0 & 4422.4 & 139.0 & 420.0 \\
\hline Qatar & QAT & 100.0 & 100.0 & 82.2 & 387.5 & 24 & $\mathrm{n} / \mathrm{a}$ & 74.0 & 100.0 & $\mathrm{n} / \mathrm{a}$ & n/a & 45.4 & 15309 & -399.0 & $\mathrm{n} / \mathrm{a}$ & 0.8 & 2.6 & 33.9 & $\mathrm{n} / \mathrm{a}$ & 4692.7 & $\mathrm{n} / \mathrm{a}$ & 26.0 \\
\hline Romania & ROU & 100.0 & 81.8 & 72.5 & 15.1 & 2129 & 105.2 & 637.0 & 100.0 & 23.7 & 39.7 & 3.5 & 2584 & 16.8 & 1.2 & 3.5 & 12.8 & 24.5 & 103.0 & 3971.2 & 135.0 & 483.0 \\
\hline Russian Federation & RUS & 96.4 & 88.8 & 79.0 & 1.4 & 29982 & 2953.0 & 460.0 & 100.0 & 3.3 & 15.9 & 11.9 & 6603 & -83.7 & 1.2 & $n / a$ & $n / a$ & 25.7 & 103.0 & 2650.4 & 138.0 & 327.0 \\
\hline Rwanda & RWA & 56.7 & 62.3 & 34.7 & 1.6 & 837 & 10.3 & 1212.0 & 29.4 & 86.7 & 56.9 & 0.1 & $\mathrm{n} / \mathrm{a}$ & $\mathrm{n} / \mathrm{a}$ & 36.1 & 2.2 & 37.9 & 4.8 & 26.0 & 1522.5 & 100.0 & 209.0 \\
\hline Samoa & WSM & 95.5 & 96.6 & 69.9 & $n / a$ & $\mathrm{n} / \mathrm{a}$ & $\mathrm{n} / \mathrm{a}$ & 1583.0 & 100.0 & 34.3 & 30.4 & 1.0 & $\mathrm{n} / \mathrm{a}$ & $\mathrm{n} / \mathrm{a}$ & 3.1 & 3.7 & 4.7 & 45.5 & 138.0 & $\mathrm{n} / \mathrm{a}$ & 129.0 & 290.0 \\
\hline Sao Tome and Principe & STP & 79.7 & 40.1 & 22.8 & 0.3 & 11398 & $\mathrm{n} / \mathrm{a}$ & 3200.0 & 65.4 & 41.1 & 10.5 & 0.6 & $\mathrm{n} / \mathrm{a}$ & $\mathrm{n} / \mathrm{a}$ & 10.2 & 4.0 & 17.2 & 10.6 & 76.0 & 2098.4 & 113.0 & 147.0 \\
\hline Saudi Arabia & SAU & 100.0 & 100.0 & 56.7 & 943.3 & 78 & $\mathrm{n} / \mathrm{a}$ & 59.0 & 100.0 & 0.0 & 0.0 & 19.5 & 9444 & -191.5 & 5.5 & 11.8 & 9.3 & 35.0 & 103.0 & 5243.3 & 135.0 & 103.0 \\
\hline Senegal & SEN & 75.2 & 48.4 & 53.3 & 8.6 & 1774 & 20.2 & 686.0 & 64.5 & 42.7 & 10.4 & 0.6 & 223 & 52.7 & 11.3 & 7.2 & 17.0 & 7.4 & 72.0 & \begin{tabular}{|l|}
1349.0 \\
\end{tabular} & 111.0 & 103.0 \\
\hline Serbia & SRB & 91.2 & 94.6 & 29.9 & 49.4 & 1179 & 73.5 & 686.0 & 100.0 & 21.2 & 26.9 & 5.3 & 4272 & 28.8 & 5.6 & 3.9 & 6.0 & 23.5 & 78.0 & 6173.5 & 110.0 & 392.0 \\
\hline Sierra Leone & SLE & 58.1 & 14.5 & 18.6 & 0.1 & 22602 & 117.2 & 2526.0 & 20.3 & 77.7 & 61.0 & 0.2 & $\mathrm{n} / \mathrm{a}$ & $\mathrm{n} / \mathrm{a}$ & 25.5 & 9.4 & 37.9 & 7.5 & 57.0 & \begin{tabular}{|l|l|}
1889.1 \\
\end{tabular} & 109.0 & 177.0 \\
\hline Singapore & SGP & 100.0 & 100.0 & 100.0 & 31.7 & 110 & $n / a$ & 2497.0 & 100.0 & 0.7 & 1.8 & 10.3 & 8845 & 97.7 & $n / a$ & 3.6 & 4.4 & 6.6 & $n / a$ & $n / a$ & $n / a$ & 5.0 \\
\hline Slovak Republic & SVK & 97.9 & 98.9 & 65.8 & 4.4 & 2325 & 26.9 & 824.0 & 100.0 & 13.4 & 22.7 & 5.7 & 5137 & 60.7 & 2.7 & 0.8 & $\mathrm{n} / \mathrm{a}$ & 22.4 & 112.0 & 6430.4 & 119.0 & 284.0 \\
\hline Slovenia & SVN & 99.5 & 99.1 & 57.9 & 6.2 & 9054 & 17.1 & 1162.0 & 100.0 & 20.9 & 29.4 & 6.2 & 6728 & 48.5 & 1.2 & 0.8 & 2.6 & 22.5 & 119.0 & 6464.4 & 127.0 & 313.0 \\
\hline Solomon Islands & SLB & 64.0 & 31.3 & 25.8 & $n / a$ & 77671 & $\mathrm{n} / \mathrm{a}$ & 3028.0 & 47.9 & 63.3 & 2.3 & 0.4 & $\mathrm{n} / \mathrm{a}$ & $\mathrm{n} / \mathrm{a}$ & 12.3 & 7.9 & 31.6 & 20.5 & 48.0 & 1657.0 & 113.0 & 202.0 \\
\hline South Africa & ZAF & 84.7 & 73.1 & 65.5 & 34.6 & 821 & 20.1 & 495.0 & 84.2 & 17.2 & 2.3 & 9.0 & 4198 & -14.5 & 6.1 & 2.5 & 27.4 & 27.0 & 83.0 & 3809.5 & 123.0 & 229.0 \\
\hline South Sudan & SSD & 50.4 & 10.4 & 38.3 & 2.5 & 2255 & 33.9 & 900.0 & 8.9 & 39.1 & 0.6 & 0.1 & 40 & -1058 & $\mathrm{n} / \mathrm{a}$ & 22.7 & 31.1 & $\mathrm{n} / \mathrm{a}$ & $\mathrm{n} / \mathrm{a}$ & 1511.8 & $\mathrm{n} / \mathrm{a}$ & 146.0 \\
\hline Spain & ESP & 99.9 & 99.9 & 82.5 & 33.0 & 2392 & 38.2 & 636.0 & 100.0 & 16.3 & 34.9 & 5.0 & 5356 & 71.4 & 1.2 & 0.8 & 2.6 & $\mathrm{n} / \mathrm{a}$ & $n / a$ & 3430.3 & $\mathrm{n} / \mathrm{a}$ & 657.0 \\
\hline Sri Lanka & LKA & 92.3 & 94.2 & 25.3 & 24.5 & 2542 & 38.5 & 1712.0 & 95.6 & 52.9 & 48.5 & 0.9 & 531 & 50.3 & 10.9 & 15.1 & 17.3 & 5.4 & 48.0 & 3897.4 & 112.0 & 121.0 \\
\hline Sudan & SDN & 58.9 & 34.6 & 39.9 & 673.3 & 102 & 15.1 & 250.0 & 38.5 & 61.6 & 64.5 & 0.3 & 190 & -9.0 & 25.2 & 16.3 & 38.2 & 7.4 & 69.0 & 684.8 & 106.0 & 163.0 \\
\hline Suriname & SUR & 94.7 & 79.2 & 15.1 & 0.6 & 180681 & 83.4 & 2331.0 & 87.2 & 24.9 & 60.1 & 3.6 & 3632 & -43.8 & 7.6 & 5.0 & 8.8 & 26.5 & 80.0 & 4433.0 & 117.0 & 248.0 \\
\hline Eswatini & SWZ & 67.6 & 58.0 & 52.6 & 39.5 & 2038 & 3.1 & 788.0 & 65.8 & 66.1 & 46.6 & 0.9 & $\mathrm{n} / \mathrm{a}$ & $\mathrm{n} / \mathrm{a}$ & 20.7 & 2.0 & $\mathrm{n} / \mathrm{a}$ & 13.5 & 44.0 & 1138.1 & 103.0 & 237.0 \\
\hline Sweden & SWE & 100.0 & 99.3 & 88.5 & 1.6 & 17636 & 104.7 & 624.0 & 100.0 & 53.2 & 63.3 & 4.5 & 13480 & 24.7 & 1.2 & 0.8 & 2.6 & 22.1 & 132.0 & 5438.2 & 126.0 & 290.0 \\
\hline Switzerland & $\mathrm{CHE}$ & 100.0 & 99.9 & 81.4 & 5.0 & 4934 & 27.3 & 1537.0 & 100.0 & 25.3 & 62.2 & 4.3 & 7520 & 50.1 & 1.2 & 0.8 & 2.6 & 21.2 & 154.0 & 5132.6 & 131.0 & 306.0 \\
\hline Syrian Arab Republic & SYR & 96.7 & 92.9 & $\mathrm{n} / \mathrm{a}$ & 198.3 & 371 & 5.6 & 252.0 & 100.0 & 0.5 & 2.3 & 1.6 & 950 & 47.8 & $\mathrm{n} / \mathrm{a}$ & 11.5 & 27.5 & 25.8 & $\mathrm{n} / \mathrm{a}$ & \begin{tabular}{|c|}
1614.7 \\
\end{tabular} & 134.0 & 255.0 \\
\hline Tajikistan & TJK & 74.1 & 95.5 & $\mathrm{n} / \mathrm{a}$ & 17.6 & 7588 & 6.8 & 691.0 & 100.0 & 44.7 & 98.5 & 0.6 & 1480 & 36.2 & $\mathrm{n} / \mathrm{a}$ & 9.9 & 26.8 & 12.6 & 59.0 & 3348.7 & 97.0 & 142.0 \\
\hline Tanzania & TZA & 50.1 & 23.5 & $\mathrm{n} / \mathrm{a}$ & 6.2 & 1608 & 56.3 & 1071.0 & 32.8 & 85.7 & 34.2 & 0.2 & 99 & 10.7 & 32.0 & 4.5 & $\mathrm{n} / \mathrm{a}$ & 4.1 & 46.0 & 1540.7 & 106.0 & 193.0 \\
\hline Thailand & THA & 98.2 & 95.0 & $\mathrm{n} / \mathrm{a}$ & 25.5 & 3281 & 189.6 & 1622.0 & 100.0 & 22.9 & 8.5 & 4.6 & 2540 & 41.6 & 9.0 & 5.4 & 10.5 & 10.8 & 59.0 & 3031.8 & 114.0 & 386.0 \\
\hline Timor-Leste & TLS & 70.2 & 44.0 & 14.1 & 14.3 & 6774 & 4.1 & 1500.0 & 63.4 & 18.2 & $\mathrm{n} / \mathrm{a}$ & 0.4 & $\mathrm{n} / \mathrm{a}$ & $\mathrm{n} / \mathrm{a}$ & 27.2 & 11.0 & 50.2 & 2.9 & 48.0 & 2454.4 & 102.0 & 96.0 \\
\hline Togo & TGO & 62.8 & 13.9 & 31.9 & 1.5 & 1591 & 8.1 & 1168.0 & 46.9 & 71.3 & 75.3 & 0.4 & 153 & 20.0 & 16.2 & 6.7 & 27.5 & 7.1 & 49.0 & 1131.4 & 114.0 & 122.0 \\
\hline Trinidad and Tobago & TTO & 96.9 & 92.1 & 25.0 & 8.8 & 2835 & 2.2 & 2200.0 & 100.0 & 0.3 & $n / a$ & 34.2 & 7134 & -102.7 & 4.9 & 6.3 & 11.0 & 19.7 & 89.0 & 1480.9 & 129.0 & 103.0 \\
\hline Tunisia & TUN & 94.2 & 93.1 & 54.5 & 76.7 & 376 & 0.7 & 207.0 & 100.0 & 12.6 & 2.8 & 2.6 & 1444 & 36.2 & 4.9 & 2.8 & 10.1 & 27.3 & 90.0 & 1541.7 & 142.0 & 358.0 \\
\hline Turkey & TUR & 98.9 & 96.4 & 69.5 & 18.5 & 2947 & 77.0 & 593.0 & 100.0 & 13.4 & 32.0 & 4.5 & 2855 & 75.2 & 1.2 & 1.7 & 9.5 & 32.2 & 120.0 & 3105.4 & 158.0 & 484.0 \\
\hline
\end{tabular}




\begin{tabular}{|c|c|c|c|c|c|c|c|c|c|c|c|c|c|c|c|c|c|c|c|c|c|c|}
\hline Turkmenistan & TKM & 94.5 & 96.6 & $\mathrm{n} / \mathrm{a}$ & 1983.6 & 257 & 5.4 & 161.0 & 100.0 & 0.0 & $\mathrm{n} / \mathrm{a}$ & 12.5 & 2679 & -191.5 & 5.5 & 4.2 & 11.5 & 17.5 & 83.0 & 1075.6 & 121.0 & 325.0 \\
\hline Uganda & UGA & 38.9 & 19.2 & 58.7 & 1.6 & 1004 & 49.2 & 1180.0 & 26.7 & 89.1 & 93.0 & 0.1 & $\mathrm{n} / \mathrm{a}$ & $\mathrm{n} / \mathrm{a}$ & 41.4 & 3.6 & 28.9 & 7.1 & 47.0 & 1906.2 & 95.0 & 120.0 \\
\hline Ukraine & UKR & 97.7 & 95.9 & 38.9 & 27.0 & 1217 & 98.1 & 565.0 & 100.0 & 4.1 & 4.4 & 5.0 & 3419 & 27.2 & 3.3 & 8.2 & 22.9 & 26.1 & 91.0 & 4652.4 & 119.0 & 589.0 \\
\hline United Arab Emirates & ARE & 99.6 & 100.0 & 74.9 & 1866.7 & 17 & $\mathrm{n} / \mathrm{a}$ & 78.0 & 100.0 & 0.1 & 0.2 & 23.3 & 11264 & -183.8 & 1.2 & 0.8 & 2.6 & 29.9 & 88.0 & 21487 & 126.0 & 66.0 \\
\hline United Kingdom & GBR & 100.0 & 99.1 & 76.7 & 5.5 & 2244 & 88.4 & 1220.0 & 100.0 & 8.7 & 24.8 & 6.5 & 5130 & 34.6 & 1.2 & 0.8 & 2.6 & 29.5 & 138.0 & 7022.6 & 138.0 & 259.0 \\
\hline United States of America & USA & 99.2 & 100.0 & $\mathrm{n} / \mathrm{a}$ & 14.9 & 8844 & 1491.0 & 715.0 & 100.0 & 8.7 & 13.2 & 16.5 & 12984 & 7.3 & 1.2 & 0.5 & 2.1 & 37.3 & 161.0 & 8142.9 & 147.0 & 704.0 \\
\hline Uruguay & URY & 99.2 & 95.7 & $\mathrm{n} / \mathrm{a}$ & 4.0 & 26963 & 134.8 & 1300.0 & 100.0 & 58.0 & 88.6 & 2.0 & 3068 & 44.4 & 1.2 & 1.3 & 10.7 & 28.9 & 103.0 & 4940.5 & 133.0 & 1152.0 \\
\hline Uzbekistan & UZB & 91.5 & 100.0 & 45.2 & 300.9 & 531 & 14.0 & 206.0 & 100.0 & 3.0 & 20.7 & 3.4 & 1645 & -26.2 & 7.4 & 4.5 & 19.6 & 15.3 & 72.0 & 4613.1 & 115.0 & 321.0 \\
\hline Vanuatu & VUT & 90.5 & 53.5 & 38.9 & $\mathrm{n} / \mathrm{a}$ & 38632 & $\mathrm{n} / \mathrm{a}$ & 206.0 & 57.8 & 36.1 & 21.3 & 0.6 & $\mathrm{n} / \mathrm{a}$ & $\mathrm{n} / \mathrm{a}$ & 7.1 & 4.4 & 28.5 & 23.5 & 104.0 & 612.5 & 128.0 & 279.0 \\
\hline Venezuela, RB & VEN & 97.4 & 94.9 & $\mathrm{n} / \mathrm{a}$ & 2.8 & 26189 & 1025.0 & 2044.0 & 99.6 & 12.8 & 63.7 & 6.0 & 2658 & -178.8 & 11.7 & 4.1 & $\mathrm{n} / \mathrm{a}$ & 25.2 & 84.0 & 3426.9 & 105.0 & 201.0 \\
\hline Vietnam & VNM & 91.2 & 78.2 & 37.7 & 22.8 & 3884 & 432.6 & 1821.0 & 100.0 & 35.0 & 36.7 & 1.8 & 1411 & -15.1 & 10.8 & 6.4 & $\mathrm{n} / \mathrm{a}$ & 2.1 & 71.0 & 5448.0 & 123.0 & 300.0 \\
\hline Yemen, Rep. & YEM & 70.4 & 59.7 & $\mathrm{n} / \mathrm{a}$ & 168.6 & 80 & $\mathrm{n} / \mathrm{a}$ & 167.0 & 71.6 & 2.3 & $\mathrm{n} / \mathrm{a}$ & 0.9 & 216 & -120.6 & 34.4 & 16.3 & $\mathrm{n} / \mathrm{a}$ & 14.1 & 45.0 & 995.3 & 95.0 & 65.0 \\
\hline Zambia & ZMB & 61.2 & 31.1 & 46.1 & 2.0 & 5134 & 49.4 & 1020.0 & 27.2 & 88.0 & 97.0 & 0.3 & 707 & 8.3 & 44.5 & 6.3 & 40.0 & 6.5 & 41.0 & 2418.0 & 93.0 & 118.0 \\
\hline Zimbabwe & ZWE & 66.6 & 38.6 & 61.0 & 29.1 & 796 & 9.3 & 657.0 & 38.1 & 81.8 & 52.7 & 0.8 & 537 & 15.3 & 46.6 & 3.2 & 26.8 & 12.3 & 58.0 & 580.0 & 87.0 & 75.0 \\
\hline
\end{tabular}


Addendum C: Conceptual Framework of WEF Nexus Index composition

\begin{tabular}{|c|c|c|c|c|c|c|}
\hline Item & Dimension/indicator & Supra-dimension & Weight & Aggregation & Direction & Name of dimension/indicator \\
\hline Index & Index & & 1 & Arithmetic & 1 & Water-Energy-Food Nexus Index \\
\hline \multirow[t]{3}{*}{ Pillars } & p.01 & si.01 & 0.333 & Arithmetic & 1 & Water sub-index \\
\hline & p.02 & si.01 & 0.333 & Arithmetic & 1 & Energy sub-index \\
\hline & p.03 & si.01 & 0.333 & Arithmetic & 1 & Food sub-index \\
\hline \multirow[t]{6}{*}{ Sub-pillars } & sp.01 & p.01 & 0.5 & Arithmetic & 1 & Access \\
\hline & sp.02 & p.01 & 0.5 & Arithmetic & 1 & Availability \\
\hline & sp.03 & p.02 & 0.5 & Arithmetic & 1 & Access \\
\hline & sp.04 & p.02 & 0.5 & Arithmetic & 1 & Availability \\
\hline & sp.05 & p.03 & 0.5 & Arithmetic & 1 & Access \\
\hline & sp.06 & p.03 & 0.5 & Arithmetic & 1 & Availability \\
\hline \multirow[t]{21}{*}{ Indicators } & ind.01 & sp.01 & 0.333 & Arithmetic & 1 & The percentage of people using at least basic drinking water services \\
\hline & ind.02 & sp.01 & 0.333 & Arithmetic & 1 & Percentage of people using safely managed sanitation services. \\
\hline & ind.03 & sp.01 & 0.333 & Arithmetic & 1 & Degree of IWRM implementation (1-100) \\
\hline & ind.04 & sp.02 & 0.25 & Arithmetic & -1 & \begin{tabular}{|l} 
Annual freshwater withdrawals, total (\% of internal resources) \\
\end{tabular} \\
\hline & ind.05 & sp.02 & 0.25 & Arithmetic & 1 & Renewable internal freshwater resources per capita (cubic meters) \\
\hline & ind.06 & sp.02 & 0.25 & Arithmetic & 1 & Environmental flow requirements (106 m3/annum) \\
\hline & ind.07 & sp.02 & 0.25 & Arithmetic & 1 & Average precipitation in depth (mm per year) \\
\hline & ind.08 & sp.03 & 0.5 & Arithmetic & 1 & Access to electricity (\% of population) \\
\hline & ind.09 & sp.03 & 0.167 & Arithmetic & 1 & Renewable energy consumption (\% of total final energy consumption) \\
\hline & ind.10 & sp.03 & 0.167 & Arithmetic & 1 & Renewable electricity output (\% of total electricity output) \\
\hline & ind.11 & sp.03 & 0.167 & Arithmetic & -1 & CO2 emissions (metric tons per capita) \\
\hline & ind.12 & sp.04 & 0.5 & Arithmetic & 1 & Electric power consumption (kWh per capita) \\
\hline & ind.13 & sp.04 & 0.5 & Arithmetic & -1 & Energy imports, net (\% of energy use) \\
\hline & ind.14 & sp.05 & 0.333 & Arithmetic & -1 & Prevalence of undernourishment (\%) \\
\hline & ind.15 & sp.05 & 0.167 & Arithmetic & -1 & Percentage of children under 5 years of age affected by wasting (\%) \\
\hline & ind.16 & sp.05 & 0.167 & Arithmetic & -1 & Percentage of children under 5 years of age who are stunted (\%) \\
\hline & ind.17 & sp.05 & 0.333 & Arithmetic & -1 & Prevalence of obesity in the adult population (18 years and older) \\
\hline & ind.18 & sp.06 & 0.25 & Arithmetic & 1 & Average protein supply (gr/caput/day) \\
\hline & ind.19 & sp.06 & 0.25 & Arithmetic & 1 & Cereal yield (kg per hectare) \\
\hline & ind. 20 & sp.06 & 0.25 & Arithmetic & 1 & Average Dietary Energy Supply Adequacy (ADESA) (\%) \\
\hline & ind.21 & sp.06 & 0.25 & Arithmetic & 1 & Average value of food production (I\$ per caput) \\
\hline
\end{tabular}




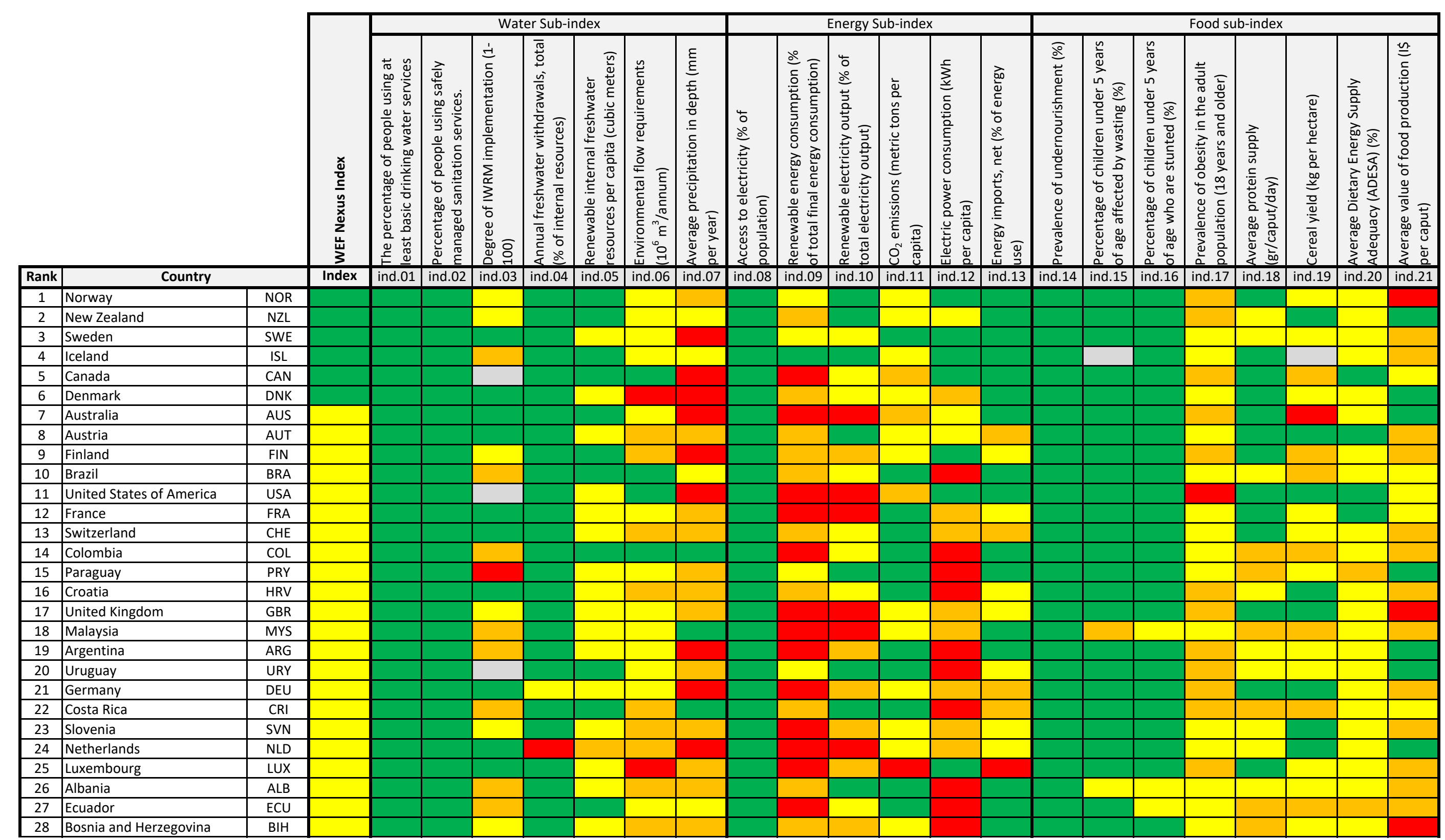




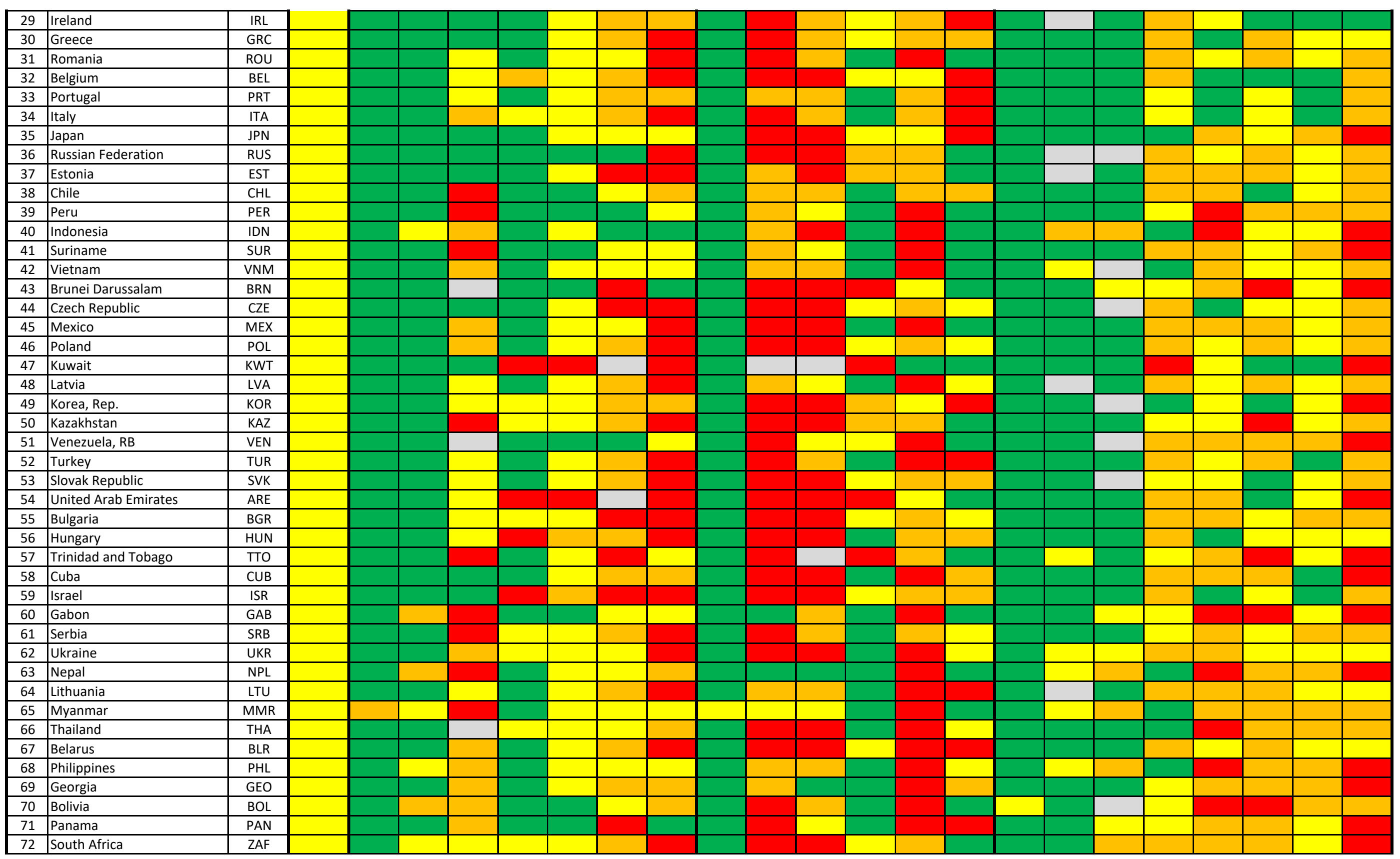




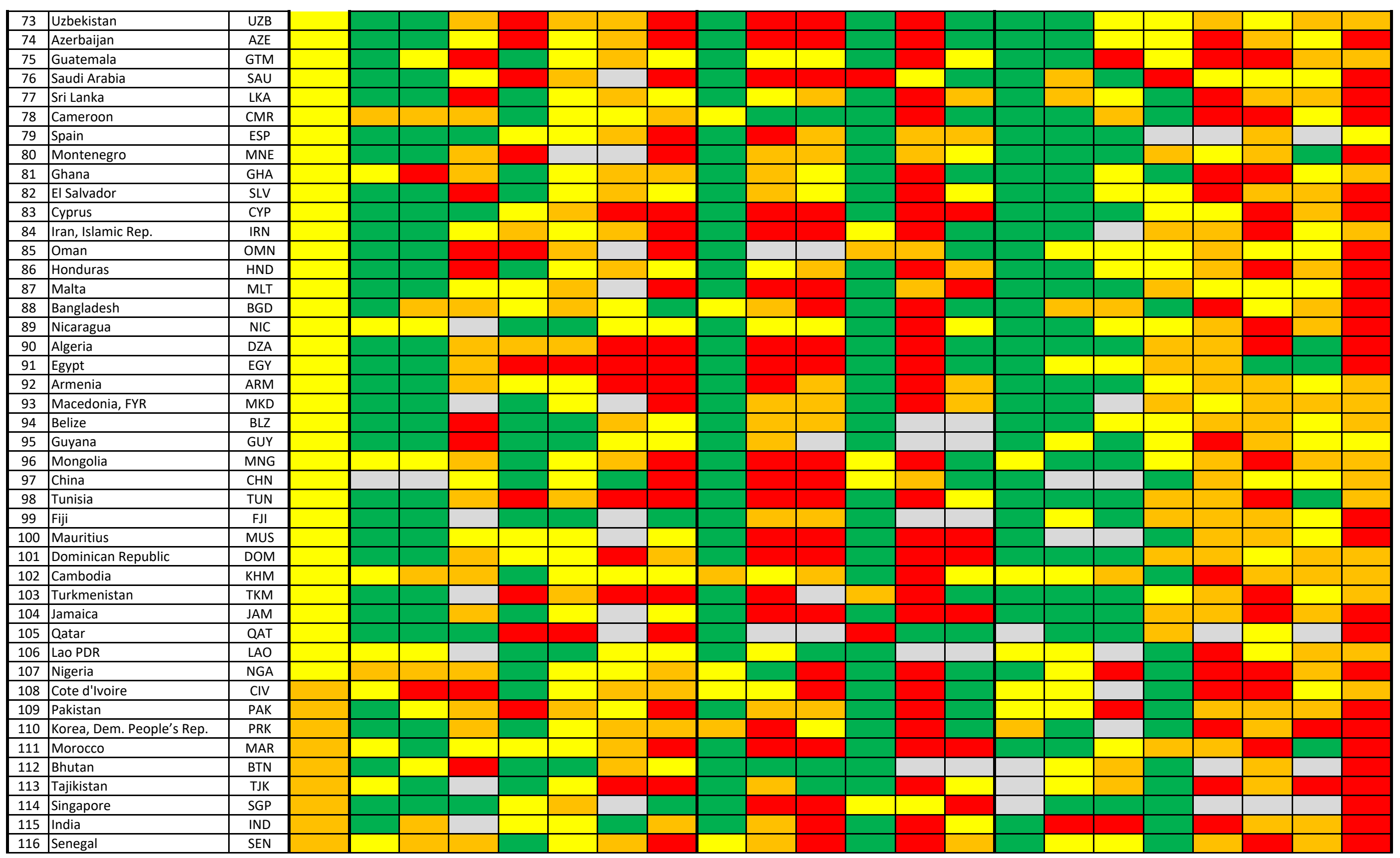




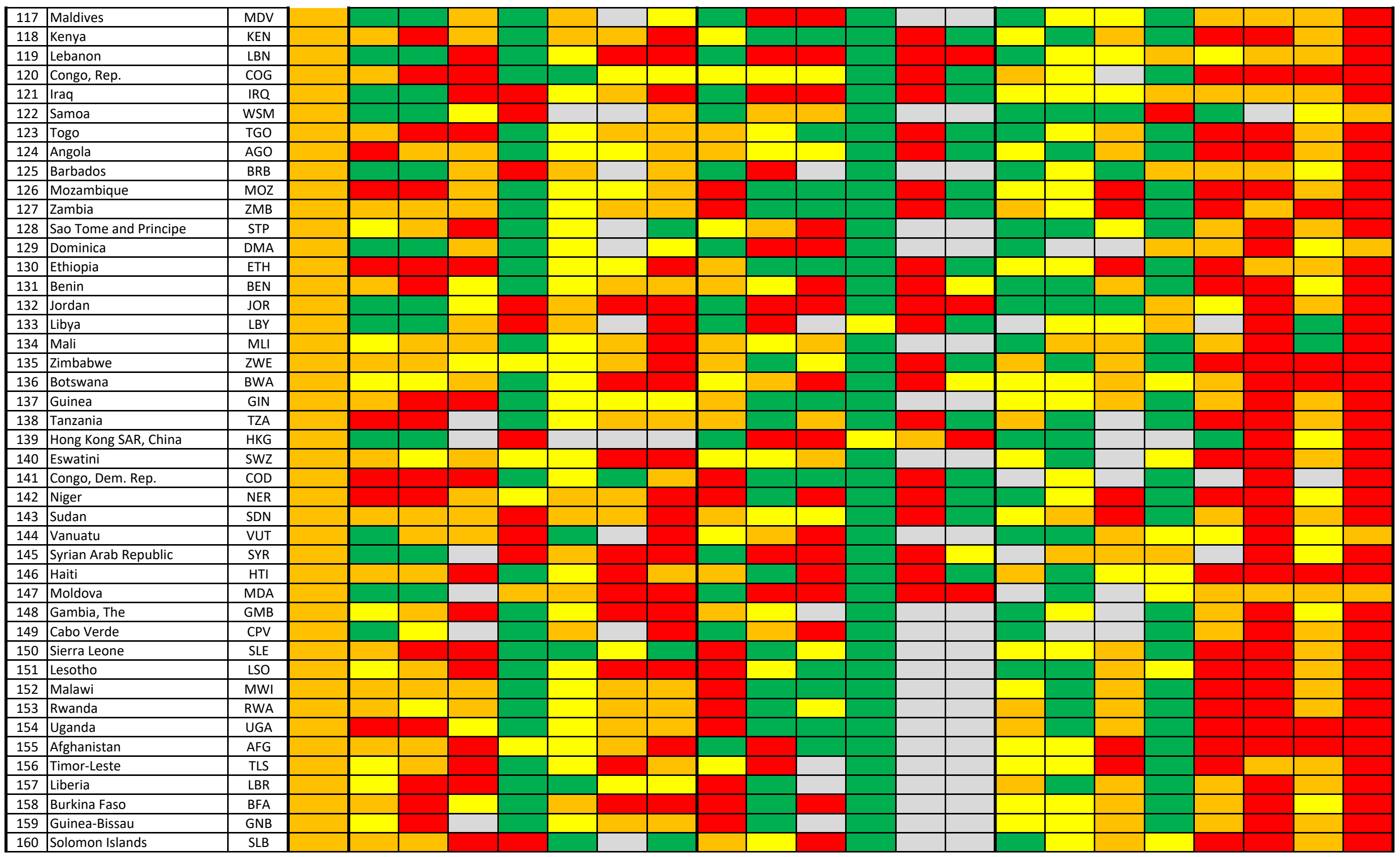




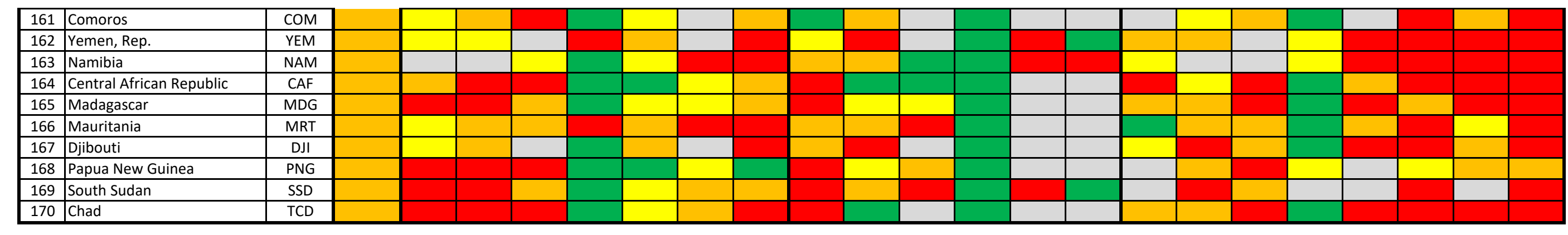

Legend: Quartiles

: values between 0 and 25

values between 25 and 50

values between 50 and 75

values between 75 and 100 to 25

: insufficient data 